\title{
ORGANIZATIONAL AND TECHNOLOGICAL, ECONOMIC QUALITY CONTROL ASPECTS IN THE CONSTRUCTION INDUSTRY
}

Collective monograph

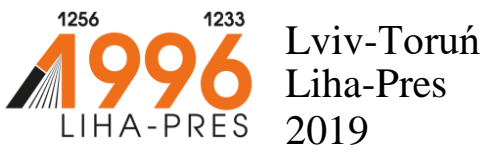




\section{Reviewers:}

Dr inż. Michat Sójka, Dean of the Faculty of Mechanical Engineering of Cuiavian University in Wloclawek (Republic of Poland);

Dr Zbigniew Brenda, Director of Logistics and Technology Institute of Cuiavian University in Wloclawek (Republic of Poland);

Prof. dr hab. Ryszard Strzelecki, Politechnika Gdańska / Gdansk University of Technology (Republic of Poland).

Organizational and technological, economic quality control aspects in the construction industry : collective monograph / O. A. Tugai, P. Ye. Hryhorovskyi, V. O. Khyzhniak, S. P. Stetsenko, etc. - Lviv-Toruń : Liha-Pres, 2019. - $136 \mathrm{p}$.

ISBN 978-966-397-166-7

Liha-Pres is an international publishing house which belongs to the category "C" according to the classification of Research School for Socio-Economic and Natural Sciences of the Environment (SENSE) [isn: 3943, 1705, 1704, 1703, 1702, 1701; prefixMetCode: 978966397]. Official website www.sense.nl. 


\title{
CONTENTS
}

\begin{abstract}
ADAPTATION OF MANAGEMENT ORGANIZATION
STRUCTURES TO CHANGES IN ACTIVITIES OF A PRINCIPAL

CONTRACTOR IN THE PROCESS OF CONSTRUCTION

ORGANIZATION BASED ON ENGINEERING METHODS

Tugai O. A.
\end{abstract}

DETERMINATION OF PERIODICITY OF INSTRUMENTAL

EXAMINATIONS SUBJECT TO EXPENDITURES

FOR OPERATION OF MEASURING SYSTEMS

Hryhorovskyi P. Ye.

STATE CONTROL, IN ACCORDANCE WITH THE

INTERNATIONAL PRACTICE, OVER MARKETING

OF IMPORTED CONSUMER PRODUCTS

Khyzhniak V. O.

STRATEGIC ASPECTS OF ECONOMIC SECURITY LEVEL FORMATION AS A PRECONDITION FOR BUILDING SAFETY

Stetsenko S. P. 62

LONG-TERM FACTORS OF CONSTRUCTION BUSINESS DEVELOPMENT

Bielienkova O. Yu. 77

STUDY OF THE TECHNOLOGY OF STRENGTHENING BRICK WALLS BY EXTERNAL REINFORCEMENT

Molodid O. S. 93

APPLIED-SCIENCE BASES OF ORGANIZATIONALTECHNOLOGICAL AND ECONOMICAL-MANAGERIAL SUPPORT OF BIOSPHERE COMPATIBLE CONSTRUCTION PROJECTS Chernyshev D. 109 


\section{ADAPTATION OF MANAGEMENT ORGANIZATION STRUCTURES TO CHANGES IN ACTIVITIES OF A PRINCIPAL CONTRACTOR IN THE PROCESS OF CONSTRUCTION ORGANIZATION BASED ON ENGINEERING METHODS}

\section{Tugai O. A.}

\section{INTRODUCTION}

Management organization engineering is defined as activities in connection with the design, implementation, and development of management systems, performed in order to enhance the efficiency of construction investment projects and construction entrepreneurial business in whole. The management organization engineering is oriented to the design and implementation of management systems, including management systems required for functioning and development of enterprises, and is mandatory part of construction investment activities because of the necessity to develop, additionally to the necessity to maintain the enterprise capital assets, an efficient management system in connection with the specified investment project. In reorganization of enterprises, the management organization engineering may be provided independent of construction investment projects. The management organization engineering methods are efficiently used for such purposes:

1. To renew the content, facilities, and objectives of business processes.

2. To exercise anti-recessionary management, specifically in the case of bankruptcy of the enterprise.

3. To enhance the efficiency of the enterprise activities by using restructuring, reconstruction, and reorganization processes.

4. To act, in accordance with decisions of antimonopoly agencies, in the case of violation of the appropriate law by the enterprise.

In general, the management organization engineering activities are classified as follows:

1. The management organization engineering activities for achieving the enterprise strategic objectives.

These activities are oriented to the making and implementation of decisions concerning the operation and development of the enterprise and the impact of the enterprise on the environment. These activities are characteristic for business management systems. 
2. The management organization engineering activities for establishing the enterprise management structure.

These activities are oriented to the making and implementation of decisions concerning the hierarchic structure of the enterprise, interaction between the enterprise operational units, and allocation of responsibility of the enterprise operational units.

3. The management organization engineering activities for maintaining management processes.

These activities are oriented to the making and implementation of decisions concerning exchange of information and technologies between the enterprise operational units.

The management organization engineering shall be actualized in an auxiliary project ${ }^{1}$, as part of the general construction investment project, or in an individual project when the management organization engineering relates to the optimization of operation, anti-recessionary management, or enforced reorganization of the existing enterprise ${ }^{2}$. Because of this, all known methods and approaches used for project management can also be used for the management organization engineering.

\section{Management organization engineering activities \\ for developing optimal management organization structure models for construction enterprises as principal contractors in implementing construction investment projects}

The management organization structure models shown in Figure 1 were developed in order to implement management organization engineering methods for modernization of management systems of construction enterprises. According to these models, the management organization process consists of four stages discussed below.

1. The stage of diagnostics for determining the management organization state at the enterprise and for justifying the necessity to change the management organization structure model for the enterprise.

2. The stage of developing the ideal management organization structure model.

3. The stage of readjustment of business processes at the enterprise in order to adapt the processes to the new management organization structure, that is, the stage of designing the management organization structure model for the state of the enterprise to be in the nearest future.

1 Bovykin V.I., New management (management of enterprises in accordance with standards: theory and practice of effective management); Moscow, Ekonomika, 1997, 302 pp.

2 Bocharov V.Y., Investment management: management of investment activities; St. Petersburg, Publishing office of the Economy and Finance University, 1999, 284 pp. 
4. The stage of implementing the new management organization structure model.

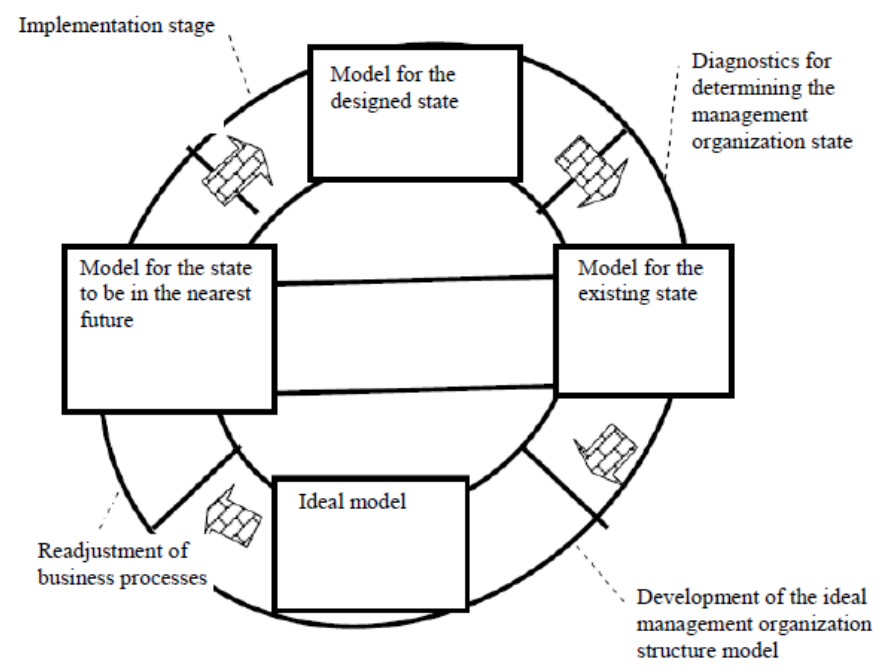

Fig. 1. Four-stage management organization process and management organization structure models

The objectives at the first stage of the management organization engineering process are the following:

1. To perform the initial diagnostics change the management of the enter4prise state in order to detect problems that caused the necessity to organization structure model.

2. To perform the detailed diagnostics of the enterprise state and collect information required for developing the new management organization structure.

3. To analyze the enterprise state in order to determine strategic objectives of the enterprise activities, including the following:

3.1. To determine the strategic areas and centers of the enterprise activities.

3.2. To determine the strategic situation of the enterprise, analyze the environment, and determine the effect of the environment on the enterprise.

3.3. To determine the key factors for the successful operation of the enterprise and determine the enterprise activity objectives.

4. To analyze the state of management and organization ate the enterprise, including the following: 
4.1. To analyze the management organization structure of the enterprise.

4.2. To analyze the management processes and the allocation of management functions and tasks at the enterprise.

4.3. To analyze the efficiency of the management system elements.

5. To analyze the financial and economic activities of the enterprise with consideration for the basic efficiency factors.

6. To analyze the enterprise data management system, including the following system elements:

6.1. Flows of documents and data at the enterprise.

6.2. Data structure.

6.3. The data communication and processing equipment such as local computer network equipment, servers, and workstations

6.4. Office equipment and its use.

7. To analyze the enterprise personnel management system, including the following:

7.1. To analyze the enterprise personnel capabilities.

7.2. To analyze the social and psychological state of the enterprise personnel.

7.3. To analyze the informal relations between the personnel members and code of behavior accepted at the enterprise.

8. To analyze the production activities and technologies of the enterprise, including the following:

8.1. To analyze the existing production processes.

8.2. To develop the management organization structure model for the existing state of the enterprise.

8.3. To perform the end-to-end analysis for determining development problems in relation to the systems, organizational structure, production processes, and other elements of the enterprise.

The objectives at the second stage of the management organization engineering process, that is, the stage of developing the ideal management organization structure model for the enterprise, are the following ${ }^{3}$ :

1. To develop and analyze the possible methods for solving the existing problems in connection with the management organization structure of the enterprise.

2. To simulate the effect of the environment on the management organization structure.

3. To develop alternative management organization structure models.

\footnotetext{
${ }^{3}$ Dmytruk I.A., Torkatiuk V.I., Mariukhin V.M., Characteristic features and basic areas of activities for enhancing efficiency of project decisions; Materials of the 23rd scientific and technical conference of the Kharkiv State Academy of Municipal Economy, Kharkiv, 2007, pp. 105-117.
} 
4. To analyze and estimate the developed management organization structure models in accordance with the criteria specified by the expert agency.

5. To determine the optimal management organization structure model.

The objectives at the third stage of the management organization engineering process, that is, the stage of readjustment of business processes at the enterprise, are the following:

1. To determine the strategic objectives of the enterprise activities.

2. To develop the management organization structure of the enterprise.

3. To develop the business and management processes of the enterprise.

4. To develop the enterprise data management system, including data flows, data structures, hardware, application software, and office equipment.

5. To develop the production processes and technologies of the enterprise.

6. To develop personnel management system of the enterprise and code of behavior at the enterprise.

7. To perform scheduling and resource planning operations.

8. To determine the economic efficiency possible in the result of implementation of the management organization structure model.

The objectives at the fourth stage of the management organization engineering process, that is, the stage of implementing the new management organization structure model for the enterprise, are the following:

1. To develop the documentation required for implementing the new management organization structure model.

2. To select personnel for implementing the new management organization structure model.

3. To respond to the opposition of the part of the enterprise personnel to organizational reassignments.

4. To control changes and compromises.

5. To control plans and determine corrective and preventive actions.

6 . To develop documentation and the management organization structure model for the designed state of the enterprise.

7. To analyze the results achieved.

8. To use the implemented management organization structure model.

9. To estimate the advantages and disadvantages of the accepted management organization structure model according to the results of the enterprise activities.

The stage of diagnostics for determining the management organization state at the enterprise includes management organization engineering activities corresponding to an individual project of the reorganization of the existing enterprise. This stage is also known as a reverse engineering stage, which objective is to develop the management organization project for the 
existing enterprise. The reverse engineering stage is followed by a direct engineering stage, which objective is to develop the management organization structure model to be implemented.

For new enterprises, the stage of diagnostics is associated with the analysis of the environment required for implementation of the investment project, as well as with the analysis of the target objectives and efficiency factors characterizing the enterprise management system.

Some objectives, which are characteristic for the management organization engineering, can be achieved by using other engineering methods. Specifically, the analysis of the financial and economic state of the enterprise is part of engineering activities for financial and economic systems, analysis of the personnel management system of the enterprise is part of engineering activities for personnel management systems, and analysis of the data acquisition and processing system of the enterprise is part of engineering activities for information systems.

The important characteristic of the management organization engineering is the unity of methods used in the reverse engineering and in the direct engineering for developing the ideal and specific management organization structure models, that is, the same methods are used for analyzing the existing business processes and for developing perspective business processes.

The management organization engineering process is illustrated by the diagram shown in Figure 1. The management organization engineering models shown on the diagram are designed for enhancing the efficiency of the enterprise management system.

The management organization engineering process is a process of transition from the stage of the project development to the stage of the project implementation, and coherent transition from the model for the existing state of the enterprise to the model for the state of the enterprise to be in the nearest future ant then to the model for the designed state of the enterprise.. Due to the management organization engineering process, the efficiency of the enterprise activities enhances. The main objectives of the management organization engineering process are to analyze the enterprise activities and use the analysis results in making decisions in connection with the enterprise management organization. So, the readjustment of the enterprise management organization structure in the case of the existing enterprise and the implementation of the management organization structure in the case of a new enterprise shall be performed in accordance with the management organization engineering process. For developing the optimal variant of the management organization structure, it is necessary to know the enterprise life cycle. The life cycle characteristic of the construction enterprise is shown in Figure 2. 


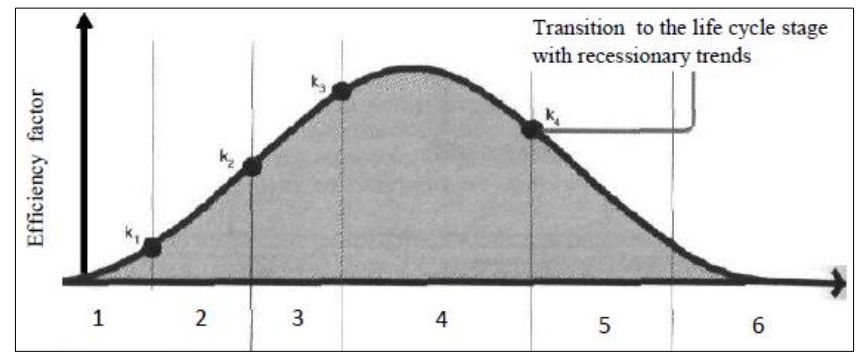

Fig. 2. Life cycle characteristic of the construction enterprise

1. Establishment of the enterprise

2. Accelerated development

3. Decelerated development

4. Normal activities

5. Recession

6. Decay

Note

The efficiency factor value shall be specified by an expert agency.

At the stage of establishment, the enterprise is characterized by enhanced expenses, and the revenues obtained from the enterprise operation do not cover the expenses, that is, the enterprise operation is unprofitable. At the beginning, the enterprise does not carry on productive activities and suffer losses due to construction, purchase, registration, or reconstruction of production buildings and rooms, supply of equipment and materials, and engaging of employees. Later, the enterprise starts productive activities but without profit. So, the enterprise activities at this stage are profitless. This stage can last for a period from several months (for enterprises that are not registered as a legal entity, or for trade and procurement enterprises) to $3 \ldots$ 4 years (for industrial enterprises).

During the life cycle, the enterprise, in the process of its development, passes over the critical point $k_{1}$ corresponding to the start of lossless activities of the enterprise, and proceeds to the stage where the cost of resources used for the enterprise operation and the income of the enterprise are equal. At this stage, the strategic potential of the enterprise is formed, and the competitive advantages of the enterprise arise.

The stage of accelerated development and the stage of decelerated development of the enterprise are characterized by sufficiently intensive activities. At the stage of accelerated development, the production capacity 
of the enterprise and, as a result, the competitive advantages, volume of production, and income of the enterprise arise.

At the stage of decelerated development, the production capacity of the enterprise decreases, and the operating efficiency of the enterprise is near maximum.

At the stage of normal activities, the operating efficiency, volume of sales of products, and income of the enterprise are maximal. The state of the enterprise is stable, and the enterprise does not extend. At this stage, the enterprise managers shall determine the conditions for extending this stage so far as is possible. At the end of this stage, the enterprise proceeds gradually to the recession stage, but maintains its market power.

The recession stage is characterized by sharp decrease of income and loss of business activity of the enterprise. This stage occurs, primarily, due to the activities of competitive enterprises and decrease of the production capacity of the enterprise. At this stage, all the finance indicators of the enterprise activities decline and the enterprise proceeds to the last life cycle stage, that is, the stage of decay.

At this stage, the enterprise suffers losses from its activities and can become bankrupt.

Ideal for the enterprise is the life cycle with the extended stage of normal activities. For construction enterprises, provided that the enterprise management is efficient in accordance with European standards, the multiperiod life cycle characteristic has been proposed (see Figure 3).

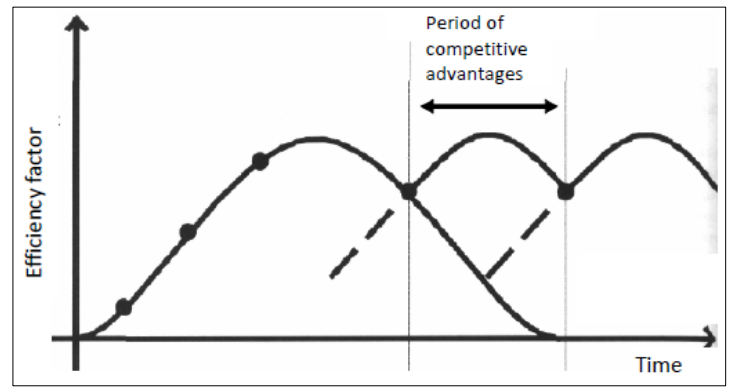

\section{Fig. 3. Multiperiod life cycle characteristic of the enterprise}

Crises are known as specific events in the enterprise life cycle. In accordance with the modern theory of enterprise development, the crisis state of the enterprise is illustrated in Figure 4. In this state, the production activity indicators of the enterprise become to be not complying with each other, and the relation between efficiency factors in performing the specified functions and processes at the enterprise sharply changes. 


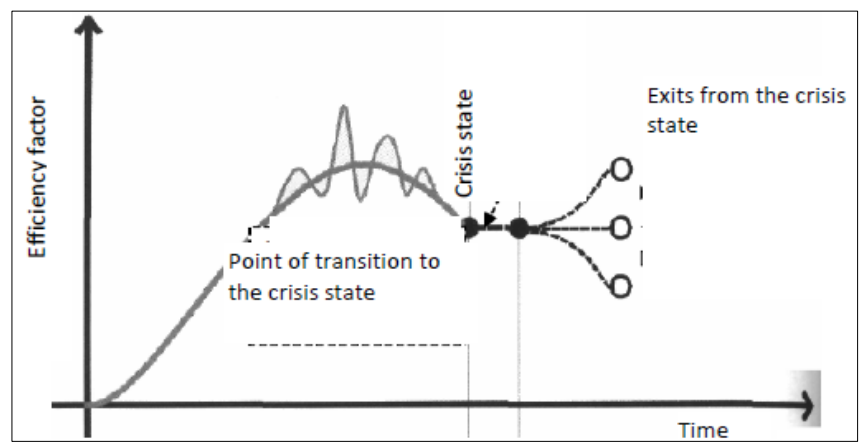

Fig. 4. Crisis state of the enterprise

In the crisis state, the production activity indicators of the enterprise are changing in a wide range, and the enterprise activities become unstable ${ }^{4}$. The instability causes loss of the financial reliability of the enterprise and, as a result, the nonequilibrium state which is characterized by the branching of the stable development possibilities for the enterprise. Depending on the enterprise management and other factors, the enterprise can choose one of the stable possibilities. In this case, the enterprise production capacity can increase or can decrease, in accordance with a steady trend, up to the bankruptcy of the enterprise.

So, the mandatory condition for efficient management organization engineering is the analysis of the enterprise characteristic features, enterprise life cycle, position of the enterprise at the market, and possible crisis events in the enterprise activities.

\section{Management organization structure models, based}

\section{on engineering methods, for construction enterprises as contractors in performing construction projects}

The management organization in the design area should be considered as organizational activity in developing management organization projects in accordance with new trends in the construction practice.

The primary document for developing the preliminary management organization project is the approved project specifications. The project specifications shall include the project justification, project objectives, requirements to the management organization structure, requirements to the

${ }^{4}$ Pokolenko V.O. and others, New methods of forming an investment portfolio in construction by optimizing the tax structure; Methods of increasing construction efficiency in market conditions, Collection of scientific papers, Kyiv, Kyiv National University of Civil Engineering and Architecture, 2006, Issue 15, pp. 3-10. 
management system, and the results of technical-economic analysis. The list of documents required for preparing the project specifications is presented in Table 1.

The preliminary management organization project shall include the results of development of the enterprise management system, description of the enterprise production structure, explanatory note to the project, and preliminary calculations of the expected economic effect.

Table 1

List of documents required for the project specifications

\begin{tabular}{|l|l|}
\hline \multicolumn{1}{|c|}{ Document } & \multicolumn{1}{c|}{ Content developer } \\
\hline $\begin{array}{l}\text { 1. Order on performing preparatory works for } \\
\text { developing the management organization project }\end{array}$ & $\begin{array}{l}\text { Manager of the construction engineering } \\
\text { company as the customer and performer } \\
\text { of the management organization project }\end{array}$ \\
\hline $\begin{array}{l}\text { 2. Methods of analyzing the state and production } \\
\text { activities of the existing enterprise }\end{array}$ & $\begin{array}{l}\text { Construction engineering company } \\
\text { together with engaged experts }\end{array}$ \\
\hline 3. Plan of the analysis & Construction engineering company \\
\hline 4. Report on the analysis results & $\begin{array}{l}\text { Construction engineering company } \\
\text { together with engaged experts }\end{array}$ \\
\hline 5. Project specifications & Construction engineering company \\
\hline
\end{tabular}

After the expert examination and approval of the preliminary management organization project, the detailed management organization project shall be developed. The objective of the detailed project is to develop the working documentation required for implementing and using the management organization structure at the enterprise. The list of documents required for the detailed management organization project is presented in Table 2.

After approval of the detailed management organization project, the project shall be implemented. At this stage, it is necessary to determine the sources of financing for the project, technical facilities, information support, and other elements of the management system, and to provide social and psychological support for the management personnel, which consists in informing the personnel about the objectives of management activities, code of behavior at the enterprise, and efficiency factors of the project to be implemented and solving social problems of the personnel.

Professional training of the management personnel is intended for the personnel development and familiarization of the personnel with new management technologies, new technical facilities, management systems, information support, and application software. Implementation of some facilities and systems may be accomplished in the process of the project 
development. It is recommended to provide a temporary promotion system for the specialists implementing such facilities and systems.

After the project implementation, the economic effect in connection with the project should be determined.

\section{List of documents required for the detailed management organization project}

\begin{tabular}{|l|c|c|}
\hline \multirow{2}{*}{ Document } & \multicolumn{2}{c|}{ To be used in: } \\
\cline { 2 - 3 } & $\begin{array}{c}\text { the management } \\
\text { system }\end{array}$ & $\begin{array}{c}\text { the subsystems of } \\
\text { the management } \\
\text { system }\end{array}$ \\
\hline $\begin{array}{l}\text { 1. List of managers and functions of the } \\
\text { managers responsible for the detailed } \\
\text { management organization project }\end{array}$ & $\times$ & $\times$ \\
\hline 2. Description of the manager functions & $\times$ & $\times$ \\
\hline $\begin{array}{l}\text { 3. Regulations for the enterprise management } \\
\text { personnel }\end{array}$ & $\times$ & $\times$ \\
\hline 4. Regulations for the manager responsibilities & & $\times$ \\
\hline $\begin{array}{l}\text { 5. Diagram of relations between the departments } \\
\text { of the management office of the enterprise }\end{array}$ & & $\times$ \\
\hline $\begin{array}{l}\text { 6. Description of the diagram of relations } \\
\text { between the departments of the management } \\
\text { office of the enterprise }\end{array}$ & $\times$ & $\times$ \\
\hline $\begin{array}{l}\text { 7. Duty regulations for the management } \\
\text { personnel }\end{array}$ & $\times$ & $\times$ \\
\hline 8. Table of the authorized management personnel & $\times$ & $\times$ \\
\hline $\begin{array}{l}\text { 9. Diagram of document workflow within the } \\
\text { enterprise management system }\end{array}$ & $\times$ & $\times$ \\
\hline $\begin{array}{l}\text { 10. Description of the diagram of document } \\
\text { workflow }\end{array}$ & $\times$ & $\times$ \\
\hline $\begin{array}{l}\text { 11. Engineering data of the management } \\
\text { facilities }\end{array}$ & $\times$ & $\times$ \\
\hline $\begin{array}{l}\text { 12. Analysis of expected economic effect due to } \\
\text { the project implementation }\end{array}$ & $\times$ & $\times$ \\
\hline $\begin{array}{l}\text { 13. Plan of measures for the project } \\
\text { implementation }\end{array}$ & $\times$ & $\times$ \\
\hline
\end{tabular}

The list of documents required for implementing the management organization project is presented in Table 3.

The methods for developing am implementing the management organization project depend on the conditions for management organization at the enterprise. 


\section{List of documents required for implementing \\ the management organization project}

\begin{tabular}{|l|c|}
\hline \multicolumn{1}{|c|}{ Document } & Content developer \\
\hline $\begin{array}{l}\text { 1. Financial plan for implementing the management } \\
\text { organization project }\end{array}$ & Customer \\
\hline $\begin{array}{l}\text { 2. Document on the material and technical resources required } \\
\text { for implementing the management organization project }\end{array}$ & Customer \\
\hline $\begin{array}{l}\text { 3. Document on the information support } \\
\text { of the management system }\end{array}$ & $\begin{array}{l}\text { Specialized agencies at the } \\
\text { expense of the customer }\end{array}$ \\
\hline $\begin{array}{l}\text { 4. Document on the social and psychological support } \\
\text { of the management personnel }\end{array}$ & $\begin{array}{l}\text { Customer } \\
\text { Designer }\end{array}$ \\
\hline $\begin{array}{l}\text { 5. Document on the professional training of the management } \\
\text { personnel }\end{array}$ & Customer \\
\hline $\begin{array}{l}\text { 6. Regulations on the promotion system for the specialists } \\
\text { implementing the project }\end{array}$ & Customer \\
\hline $\begin{array}{l}\text { 7. Calculations for determining the actual economic effect } \\
\text { due to the project implementation }\end{array}$ & Customer with designer \\
\hline 8. Report on the commissioning the project & $\begin{array}{l}\text { Customer } \\
\text { Designer }\end{array}$ \\
\hline
\end{tabular}

The results of research activities and propositions of the author of this paper, concerning the elements of the management systems and management organization structures designed for building enterprises as subjects of research, were verified in the process of practical activities of the construction engineering company «Construction and ecology». When developing the management organization project, characteristic features of construction enterprises, mutual relations of the construction enterprises with investors, and methods for estimating variants of the management organization structure were considered ${ }^{5}$.

In accordance with the discussed methods for developing management organization projects, the special procedure for developing management organization structures for construction enterprises has been proposed. This procedure is illustrated in Figure 5.

For the construction engineering company «Construction and ecology», several alternative variants of the management organization structure were proposed. These variants were compared in accordance with the technique discussed below.

${ }^{5}$ Pokolenko V.O. and others, New conceptual and analytical facilities for justification, preparation, and implementation of investment projects in construction; Monography under the editorship of Pokolenko V.O., Kyiv, Publishing office of the European University, 2008, 208 pp. 
The accepted variant of the management organization structure for the construction engineering company «Construction and ecology» is illustrated in Figure 6. The proposed management organization structure is designed as a multipurpose structure in which, in accordance with the theory of hierarchical systems, all the elements can take decisions and have various, even conflicting, objectives. Such contradictions are caused by the element specialization and are required for effective management of an enterprise. In a system with the multipurpose structure, the higher level elements enable the purposeful activities of the lower level elements but do not control the lower elements completely ${ }^{6}$.

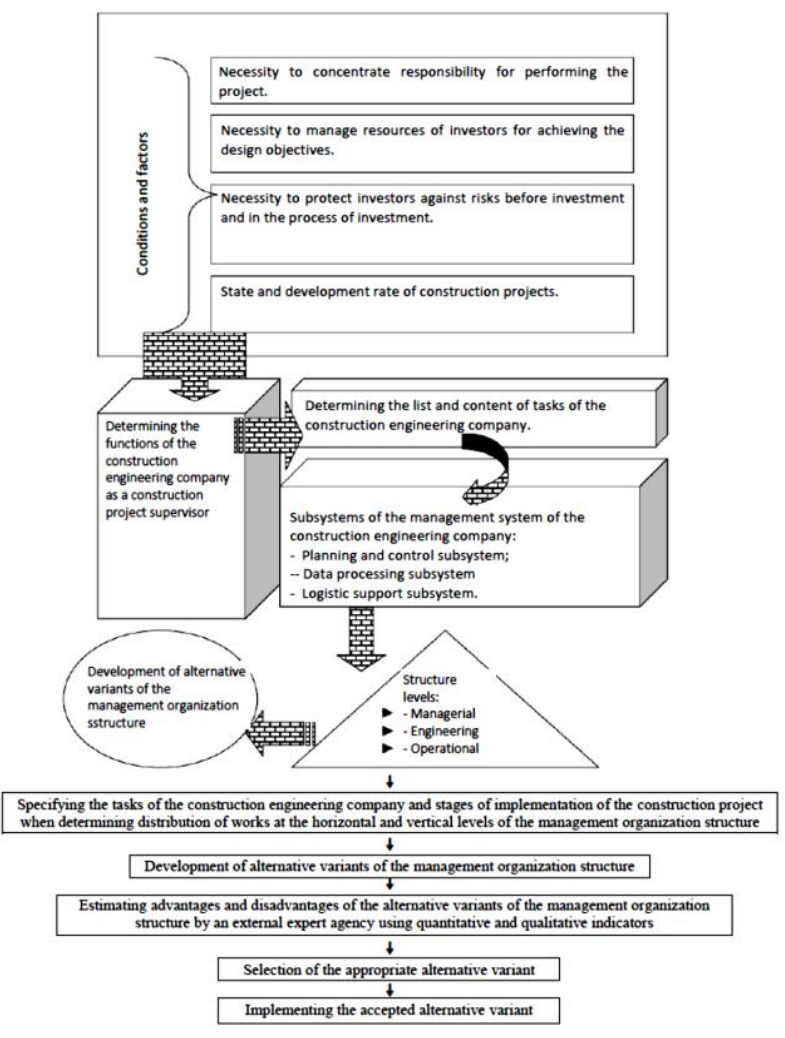

\section{Fig. 5. Procedure for developing the management organization structure of the construction engineering company}

${ }^{6}$ Tugai O.A., Lagutin G.V., New subjects of construction organization: methods, information base, and implementation practice; Monography, Publishing office of the European University, 2006, $180 \mathrm{pp}$. 


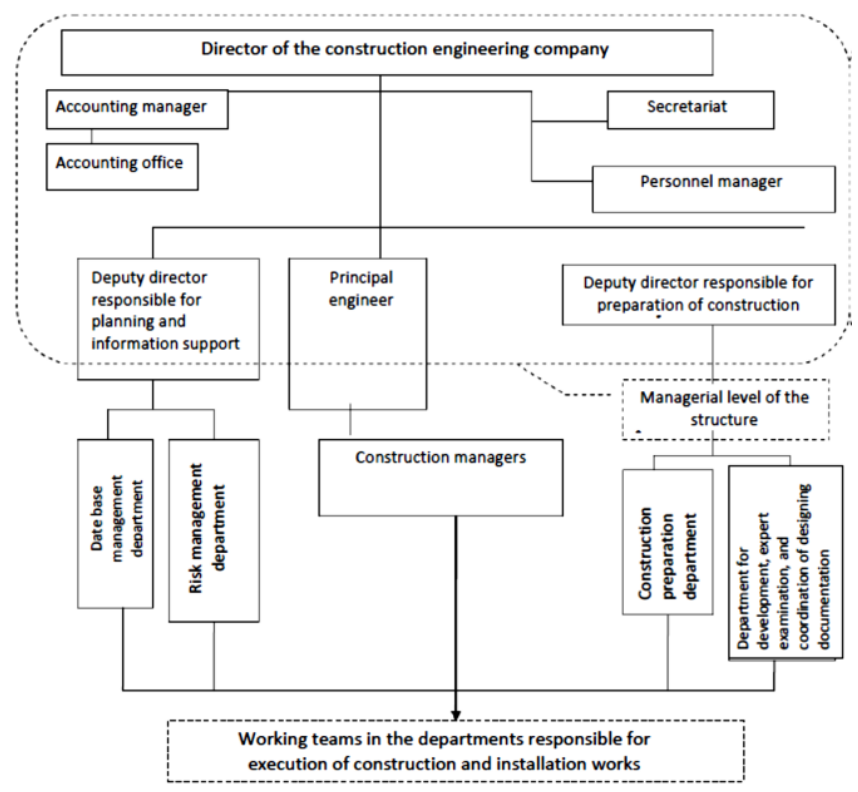

Fig. 6. Variant of the management organization structure of the construction engineering company
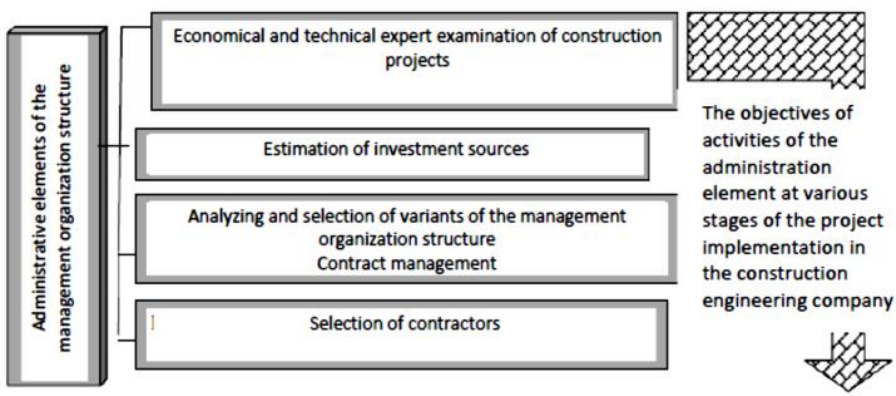

1. To analyze investment propositions, project objectives, and designing documentation 2. To analyze the proposed sources of financial support required for preparing and performing construction and installation works

3. To make decisions in relation to investors and the construction engineering company as a leading company in planning,. preparing, and performing construction and installation works

Fig. 7. Administrative elements of the management organization structure of the construction engineering company 
The lower level elements are free in taking decisions. This freedom is characteristic for any multilevel hierarchic system, and in the proposed management organization structure, management is provided by coordination of decisions accepted at the upper level with decisions accepted by the corresponding analytical and expert institutions.

The management organization structure (see Figure 6) is characterized by traditional advantages of function-branching structures, distribution of works, and hierarchic subordination of the structure elements ${ }^{7}$.

The managerial level of the management organization structure is represented by the manager of the enterprise and his deputies, which coordinate the enterprise activities and relations of the enterprise with investors, project performers, and other participants of the construction project.

The medium level of the management organization structure is represented by the experts of the following departments ${ }^{8}$ :

1. The department for risk management

2. The department for development, expert examination, and coordination of designing documentation

3. The planning and analysis department

4. The department for preparation of construction and installation works

5. The department for organization of construction and installation works

The lower level of the management organization structure is represented by the experts of the project management department.

The department for risk management is designed for performing special functions, such as estimating investment propositions, strategic objectives of the project, designing documentation, and sources of financing, and for making decisions concerning the activities of the construction engineering company as a principal contractor in performing construction and installation works.

The department for development, expert examination, and coordination of designing documentation is represented by the manager of the

${ }^{7}$ Tugai O.A., Multi-stage engineering model for organization of interaction between the principal contractor and the customer; Tugai O.A., Construction engineering, Kyiv, Kyiv National University of Civil Engineering and Architecture, 2008, No. 21, pp. 85-97.

${ }^{8}$ Tugai O.A., The functional-technical factor of efficiency of projects and structures of construction engineering companies as a new parameter in simulation of construction; Tugai O.A., Applied geometry and engineering graphics, Interdepartmental collection of scientific papers, Kyiv, Kyiv National University of Civil Engineering and Architecture, 2008, Issue 79, pp. 140-150. 
department, principal project architect, principal project engineer, architects, managers for contract administration, economists, operators of the computeraided design system, and operators of the automated cost calculation system ${ }^{9}$.

The planning and analysis department is designed for performing the following tasks:

1. Developing logistic schedules

2. Financial planning and selection of source of financing

3. Scheduling the project works and control resources required for performing the project

The department for preparation of construction and installation works is designed for performing the following tasks:

1. Selection of contractors for performing construction and installation works

2. Preparation of construction and installation works

3. Logistical organization

4. Rent of construction equipment

In order to prevent the inadaptability of enterprises tor rapid changes, the department for preparation of construction and installation works shall perform functions of a project supervisor.

The personnel of this department are represented by managers and constructing engineers, such as the following:

1. The manager and constructing engineers responsible for engineering works

2. The manger and constructing engineers responsible for operation of construction equipment

3. The manager and constructing engineers responsible for underground works

6. The manager and constructing engineers responsible for finishing works

7. The manager and constructing engineers responsible for special works

With consideration for special functions to be performed by the managers and constructing engineers of this department, the department should be decentralized. In this case, the medium level managers can make important decisions with consideration for motivating factors for these

${ }^{9}$ Tugai O.A., Method of functional-technical reorganization of construction; Tugai O.A., Town development and territorial planning, Collection of scientific papers, Kyiv, Kyiv National University of Civil Engineering and Architecture, 2006, Issue 30, pp. 398-419. 
decisions, and for this purpose, the management organization structure projects should be performed with consideration for the possibility for managers to propose, at special meetings, means for improving the management organization structure. The meetings shall be held under control of top managers, but when the decision is approved, it is mandatory for all the meeting participants.

The approved variant of the management organization structure allows for planning construction works, legal support of construction projects, effective relations with central and local authorities, and management of constriction objects in accordance with the specified requirements and coordinated interests and actions of all the project participants.

The approved variant of the management organization structure for the construction engineering company «Construction and ecology» complies with the objectives of the company as the administrator of investments and regulator of business processes.

The administrative elements of the management organization structure of the construction engineering company are shown in Figure 8.

The variant of the management organization structure for the UkrainianTurkish company «Ashgel Construction» is illustrated in Figure 9.

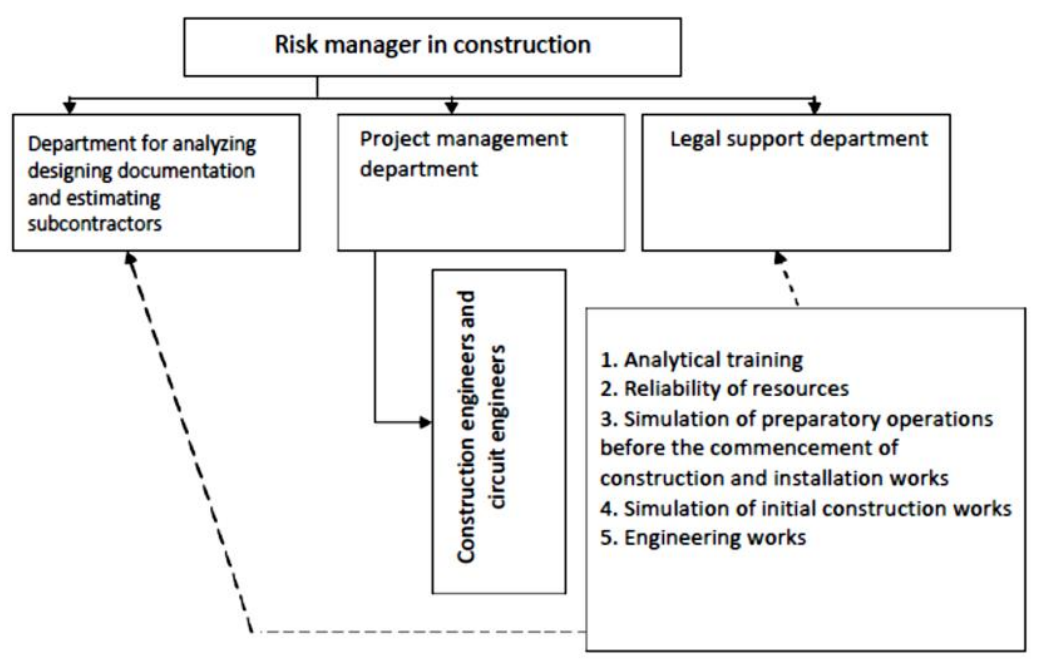

Fig. 8. Administrative elements of the management organization structure of the construction engineering company 


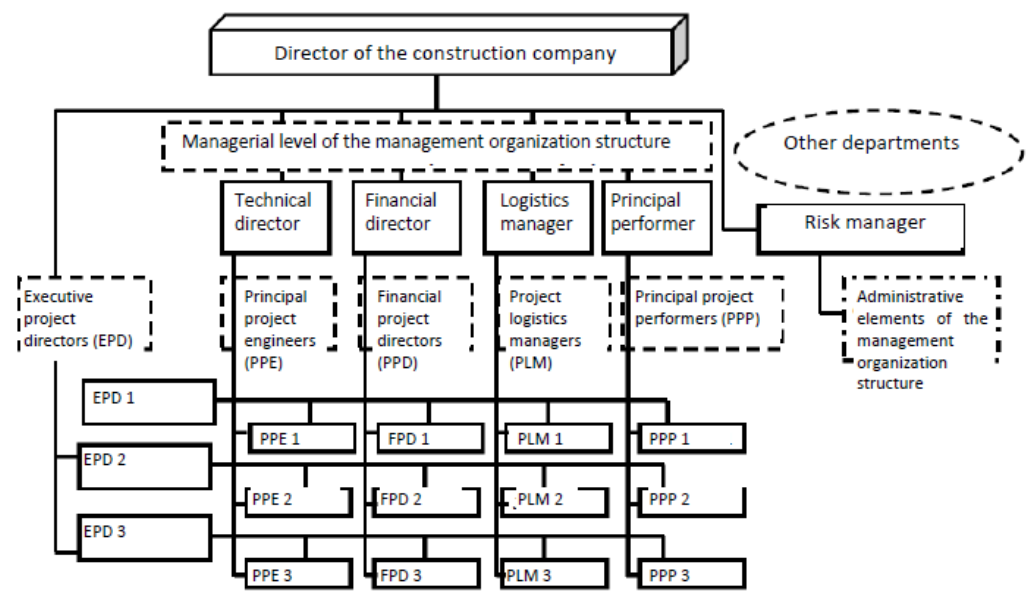

Fig. 9. Variant of the management organization structure for the Ukrainian-Turkish company «Ashgel Construction»

In this paper, the method for estimating the efficiency of variants of the management organization structure for construction engineering companies is proposed by using a special efficiency factor $U^{\prime s t r}$ depending on the structure characteristic features listed in Table 4.

The efficiency factor $U^{\prime \prime s t r}$ shall be determined by equation (1).

$$
\tilde{U}^{\prime s t r}=\left[1 /\left(m \cdot \mathrm{n}_{m} R g_{m}\right] \cdot \mathrm{n}_{m} \hat{S}_{m} ; R g_{m} \geq 1,\right.
$$

where:

$$
\hat{S}_{m}=\left(1 / \mathrm{n}_{z} R g_{z}\right) \cdot \mathrm{n}_{z} R g_{z} \hat{S}_{m z} ; z=1 \mathrm{n} N z ; R g_{z} \geq 1,
$$

$U^{\prime s t r}$ is the summary efficiency factor value presented as a rational number;

$m$ is the index equal to the sequential number of the corresponding characteristic feature in the list in Table 4;

$N$ is the total number of characteristic features in the list in Table 4;

$z$ is the index equal to the sequential number of the corresponding expert in the list of experts;

$\hat{S}_{m z}$ is the efficiency factor proposed by the $z$ th expert, according to the $m t h$ characteristic feature, for the variant of the management structure;

$\hat{S}_{m}$ is the efficiency factor accepted by all the experts; 
$R g_{z}$ is the indicator of importance of the expert efficiency factor for the $m t h$ characteristic feature relative to the efficiency indicator accepted by all the other experts;

$\mathrm{Rg}_{\mathrm{m}}$ is the indicator of the priority of the mth characteristic feature relative to the other characteristic features.

Table 4

\section{List of characteristic features in estimating the efficiency of variants of the management organization structure for construction engineering companies}

\begin{tabular}{|l|c|}
\hline \multicolumn{1}{|c|}{ Characteristic feature } & $\begin{array}{c}\text { Relative priority } \\
\text { indicator (Rg } \mathbf{m} \text { ) }\end{array}$ \\
\hline $\begin{array}{l}\text { 1. Adaptability } \\
\text { The capability of the management organization structure to allow for } \\
\text { performance of specified function of the enterprise within a range of } \\
\text { various conditions. The wider is the range, the more adaptable is the } \\
\text { management organization structure. }\end{array}$ & 1.11 \\
\hline $\begin{array}{l}\text { 2. Adjustability } \\
\text { The capability of the enterprise administration to make decisions and } \\
\text { enter into new relations, in response to new objectives of the enterprise } \\
\text { activities, without changes in the enterprise hierarchical structure. }\end{array}$ & 1.045 \\
\hline $\begin{array}{l}\text { 3. Operational efficiency in taking managerial decisions } \\
\text { The capability of the enterprise administration to promptly determine } \\
\text { problems in the enterprise management and solve the problems detected } \\
\text { as needed for achieving the specified objectives on retention of the } \\
\text { existing production environment at the enterprise. }\end{array}$ & 1.072 \\
\hline $\begin{array}{l}\text { 4. Minimization of conflicts between the elements of the management } \\
\text { organization structure. }\end{array}$ & 1.0 \\
\hline $\begin{array}{l}\text { 5. The capability of the management organization structure to provide } \\
\text { adequate working conditions for making decisions and carry out actions } \\
\text { for the personnel involved in the management organization. }\end{array}$ & 1.0 \\
\hline $\begin{array}{l}\text { 6. Promotion of team spirit at all the levels an in all the departments of } \\
\text { the enterprise. }\end{array}$ & 1.0 \\
\hline $\begin{array}{l}\text { 7. Information capacity of the enterprise communication system, the } \\
\text { number and quality of feedback links in information interchange } \\
\text { between the managers and employees of the enterprise }\end{array}$ & 1.09 \\
\hline $\begin{array}{l}\text { t8. Time of response as an interval between the start a management } \\
\text { action and the response to the action }\end{array}$ & \\
\hline
\end{tabular}

The development of management organization structures is associated with difficulties. With consideration for the complexity of large enterprises, 
it is necessary to develop methods for determining the practicability and efficiency of changes in the management organization structure of the enterprise. Special attention should be given to the adaptability of the management organization structure to changing conditions in the process of the enterprise development.

In order to reliably estimate the compliance of the management organization structure of the enterprise with the requirements of the investor, it is necessary to use two estimation scales, that is, a semantic scale, with estimates ranged from a «bad estimator» to a «high estimate», and a numerical scale with estimates ranged from 0.75 to 1.05 .

The proposed management organization structure complies with the characteristic features of construction enterprises. The semantic an numerical estimation scales provide the possibility to determine the compliance of the management organization structure with the specified requirements and, as a result, to reduce expenses for reorganization of the enterprise, reduce the operational expenses of investors, and create conditions for activities of construction engineering companies in controlling investment resources in the process of preparing and implementing construction projects.

\section{CONCLUSIONS}

1. Management organization structure models are developed for construction enterprises with consideration for changes in the activities of the enterprise as a principal contractor ${ }^{10}$.

2. The management organization structure models are developed so as to effectuate all the advantages characteristic for the functional and administrative elements of management organization structures.

3. Special attention is given to the administrative elements of management organization structures, specifically to the department for risk management. The activities of the construction enterprise departments shall be oriented to perform such special functions as estimation of investment propositions, project objectives, design documentation, and sources of financial support, and to make decisions concerning relations of the enterprise as a principal contractor.

${ }^{10}$ Tugai O.A., Forming of the research and information basis for taking into account stochastic factors in construction organization and for preventing failures of organizational systems; Tugai O.A., Construction engineering, Kyiv, Kyiv National University of Civil of Engineering and Architecture, 2007, Issue 20, pp. 97-104. 
4. The proposed management organization structure complies with the characteristic features of construction enterprises. The semantic and numerical estimation scales provide the possibility to determine the compliance of the management organization structure with the specified requirements and, as a result, to reduce expenses for reorganization of the enterprise, reduce the operational expenses of investors, and create conditions for activities of construction engineering companies in controlling investment resources in the process of preparing and implementing construction projects.

\section{SUMMARY}

This paper concerns the development of new theoretical concepts and methods for the adaptation of management organization structures in construction to the current conditions. The novelty of the proposed methods consists in that these methods are developed on the engineering basis with consideration for changes in the operational and management activities of construction enterprises as principal contractors, implementation of new functional end engineering construction standards designed for verifying the quality of construction project decisions, and the capabilities of the project management personnel.

In order to improve the quality of construction and installation works and provide the compliance of construction objects with the specified requirements, it is necessary to develop new management organization models to be used in the process of interaction between the principal contractor and the customer. The interaction process is divided into 9 stages ranged from the stage of construction preparation to the stage of commissioning the construction object, and provides fob the assignment of a principal contractor with responsibility, according to the contract, for the following:

1. Proper use of the construction project resources.

2. Logistic and maintenance support of the construction project.

3. Timeliness of performing construction and installation works.

4. Compliance with the requirements of the appropriate standards.

In order to adapt the management organization methods to the current market requirements, the methods and models are developed with consideration for the new functions of construction engineering companies, risks in performing construction and installation works, necessity to 
introduce changes in the process of performing construction and installation works, and the requirements of new functional end engineering standards.

These methods and models provide the possibility to develop optimal management organization structures for construction engineering companies as principal contractors and to reduce expenses when performing analysis of the company activities at the preinvestment stage.

The results of research activities discussed in this paper provide the possibility to optimize management organization structures of construction enterprises. The proposed management organization structures comply with the process of intensive reorganization of the construction industry of Ukraine and provide favorable conditions for construction enterprises as principal contractors.

\section{REFERENCES}

1. Bovykin V.I., New management (management of enterprises in accordance with standards: theory and practice of effective management); Moscow, Ekonomika, 1997, 302 pp.

2. Bocharov V.Y., Investment management: management of investment activities; St. Petersburg, Publishing office of the Economy and Finance University, 1999, $284 \mathrm{pp}$.

3. Dmytruk I.A., Torkatiuk V.I., Mariukhin V.M., Characteristic features and basic areas of activities for enhancing efficiency of project decisions; Materials of the 23rd scientific and technical conference of the Kharkiv State Academy of Municipal Economy, Kharkiv, 2007, pp. 105-117.

4. Pokolenko V.O. and others, New methods of forming an investment portfolio in construction by optimizing the tax structure; Methods of increasing construction efficiency in market conditions, Collection of scientific papers, Kyiv, Kyiv National University of Civil Engineering and Architecture, 2006, Issue 15, pp. 3-10.

5. Pokolenko V.O. and others, New conceptual and analytical facilities for justification, preparation, and implementation of investment projects in construction; Monography under the editorship of Pokolenko V.O., Kyiv, Publishing office of the European University, 2008, 208 pp.

6. Tugai O.A., Lagutin G.V., New subjects of construction organization: methods, information base, and implementation practice; Monography, Publishing office of the European University, 2006, $180 \mathrm{pp}$.

7. Tugai O.A., Multi-stage engineering model for organization of interaction between the principal contractor and the customer; Tugai O.A., 
Construction engineering, Kyiv, Kyiv National University of Civil Engineering and Architecture, 2008, No. 21, pp. 85-97.

8. Tugai O.A., The functional-technical factor of efficiency of projects and structures of construction engineering companies as a new parameter in simulation of construction; Tugai O.A., Applied geometry and engineering graphics, Interdepartmental collection of scientific papers, Kyiv, Kyiv National University of Civil Engineering and Architecture, 2008, Issue 79, pp. 140-150.

9. Tugai O.A., Method of functional-technical reorganization of construction; Tugai O.A., Town development and territorial planning, Collection of scientific papers, Kyiv, Kyiv National University of Civil Engineering and Architecture, 2006, Issue 30, pp. 398-419.

10. Tugai O.A., Forming of the research and information basis for taking into account stochastic factors in construction organization and for preventing failures of organizational systems; Tugai O.A., Construction engineering, Kyiv, Kyiv National University of Civil of Engineering and Architecture, 2007, Issue 20, pp. 97-104.

\section{Information about the author:}

Tugai O. A.,

Doctor of Engineering Science, Professor, Head of the Construction Organization and Management Department, Kyiv National University of Civil Engineering and Architecture 31, Povitroflotskyi ave., Kyiv, 03037, Ukraine 


\section{DETERMINATION OF PERIODICITY OF INSTRUMENTAL EXAMINATIONS SUBJECT TO EXPENDITURES FOR OPERATION OF MEASURING SYSTEMS}

\section{Hryhorovskyi P. Ye.}

\section{INTRODUCTION}

An important problem in studies of natural and man-caused processes during construction and operation of buildings is an investigation of interference between construction activities, surrounding territories and adjacent developed areas. Defects and damages of buildings that have been untimely detected result in material losses, damages to society and environment. Therefore it is necessary to evaluate the state of buildings in proper time, predict a possible trend in the development of defects and damages and establish measures for their stabilization or removal. For this purpose a better understanding of mechanisms of destruction and deterioration of structural elements during construction and operation and capability to evaluate the effects of environmental factors are needed. And such an understanding and capability are impossible without actual data obtained by instrumental measurements. The instrumental measurements are integral parts of technological processes at all stages of the building life cycle and affect their organizational-technological and technical indices. Therefore the determination of periodicity of instrumental examinations subject to expenditures for operation of measuring systems is an urgent scientific and technical issue.

\section{Determination of periodicity of activities on performing instrumental examinations}

Generally, the periodicity of planned examinations is specified on the basis of data on buildings under average service conditions. According to recommendations specified in the works ${ }^{1,2}$ the terms of examinations should be established with an allowance for a level of safety that is characterized by reliability, ecological safety and corrosiveness of environment, structural

1 Ivanyk I.H. Principles of reconstruction of buildings and structures / I.H. Ivanyk, S.I. Vikhot', R.S. Ivannyk, Yu.Yu. Vybranets'; ed. I.H. Ivanyk. - L'viv: Publishers L'viv Politekhnika, 2010. - 276 p. (in Ukrainian).

${ }^{2}$ Normative documents on issues of examinations, certifications, safe and reliable operation of production buildings and structures. - K.: NDIBV, 2003. - 144 p. (in Ukrainian). 
features, and characteristics of bases, availability of stationary instrumentation, experience in operation of similar buildings. The periodicity of planned examinations $T_{n}$ is specified on the assumption of a possibility to maintain the facility service conditions until the next examination and expressed as

$$
\mathrm{T}_{\mathrm{\Pi}}=\mathrm{T}_{6} \cdot \mathrm{K}_{6}
$$

where $T_{6}$ is the term until the first planned examination for buildings under average conditions of operation;

$\mathrm{K}_{\sigma}$ is the safety factor defined by expression

$$
\mathrm{K}_{6}=\gamma_{\mathrm{n}} \cdot \mathrm{K}_{\mathrm{eK}} \cdot \mathbf{K}_{\mathrm{ar}}
$$

where $\gamma_{n}$ is the reliability factor for purpose, it numerically characterizes a degree of reliability of buildings and varies from 1,25 (the most reliable structures) to 0,8 (the least reliable structures);

$\mathrm{K}_{\mathrm{eK}}$ is the coefficient that characterizes the environmental unsafety of production and varies from 0,8 (unsafe production) to 1,0 (safe production);

$\mathrm{K}_{\mathrm{ar}}$ is the coefficient of environment corrosiveness effect that varies from 0,7 (heavy corrosive environment) to 1,0 (non-corrosive environment).

In our opinion the above method is lacking in recommendations with respect to the correction of $T_{6}$ values. The average service conditions may be justified when statistic data for a great number of buildings of the same type under similar operating conditions are available. And the measuring equipment is only available if it has been specified in the project. The recommendations don't account for dynamical changes in building operating conditions and their consequence class. Though the safety factor can characterize the class of consequences but according to (2) it characterizes the degree of stability and reliability namely for the higher degree the period between examinations is longer. To account for the class of consequences the level of responsibility shall be increased and the period of examinations shall be simultaneously shortened. It is difficult to predict variations of material properties in time for a long-term period without statistical or laboratory tests for ageing processes which are complicated by service conditions. 
The method for determination of structure maintenance periodicity on the basis of data on structural reliability (failure rate) ${ }^{3}$ provides for determination of the maintenance and repair periodicity $t_{\text {пр }}$ at which the probability of no-failure operation is less than a specified value $\mathrm{P}<1$.

$$
\mathrm{P}\left(\mathrm{t}_{\text {пр }}\right)=\mathrm{e}^{-\lambda \mathrm{t}_{\text {пр }}} \text {, }
$$

where $\lambda$ is the failure rate.

To simplify calculations it is anticipated that after $t_{\text {пр }}$ the capacity for work will be immediately renewed in full and a new countdown of the service life will begin. In this case a change in the failure probability $\mathrm{Q}$ during operation is shown in Fig. 1.

If $\mathrm{P}_{0}$ is a probability of no-failure operation then the following condition shall be true

$$
\mathrm{P}\left(\mathrm{t}_{\text {пр }}\right)=\mathrm{e}^{-\lambda \mathrm{t}_{\text {пр }}} \geq \mathrm{P}_{0}
$$

Then if follows

$$
\frac{\mathrm{t}_{\text {пр }}}{\mathrm{t}_{\text {cep }}} \leq-\ln \mathrm{P}_{0},
$$

where $t_{\text {cep }}=\frac{1}{\lambda}$ is a mean time between failures;

$\lambda$ is a failure ratio.

Thus if $P_{0}=0,9$ then $t_{\text {пр }} \leq 0,105 \cdot t_{\text {сер }}$. That is for ensuring the $90 \%$ probability of no-failure operation it is necessary to perform the repair operations which renew operating conditions in full ten times. If an actual time of renewal of the capacity for work is accounted for the calculations are more complex but this does not affect the result. This method only accounts for statistic data on a mean time between failures but such data are not available in the construction industry. Any class of consequences and foundation features are not accounted for in the method for determination of periodicity. The above method for determination of periodicity may be only used during the period of regular operation when the failure rate is stable. In

\footnotetext{
${ }^{3}$ Petrov E.G. Methods and means for making decisions in economic and technical systems / E.G. Petrov, M.V. Novozhilova, I.V. Grebennik, N.A. Sokolova; under the general editorship of E.G. Petrov. - Kherson: OLDI-plus, - 2003. - 378 p. (in Russian).
} 
arranging a deformation monitoring system this fact may introduce errors in the validity of obtained data or result in an increase of cost of measuring operations.

In our opinion, an algorithm of determination of periodicity of instrumental examinations of structures shall be based on the same principles namely on the comparison of controlled parameters $\Pi_{\mathrm{i}}$ with the estimated (predicted) values $\Pi_{\mathrm{i}}^{\prime}$.

The maximum allowed value of the controlled parameter $\Pi_{i}$ is defined as follows

$$
\Pi_{\max }=\Pi_{i}^{\prime}+\Delta \Pi_{i}
$$

where $\Delta \Pi_{i}$ is the range of possible allowable deviations of the controlled parameter $\Pi_{\mathrm{i}}$.

Estimated values $\Pi_{i}^{\prime}$ are determined on the basis of mathematical modelling and adjusted as part of the research and development support of construction. The maximum allowable value of parameter $\Pi_{\max }$ is calculated at the stage of designing and also adjusted while performing the research and development supporting work. The rate of changes in parameter $\Pi_{i}$, which equals $\mathrm{V}=\frac{\Delta \Pi}{\Delta \mathrm{t}}$, is determined at the stage of designing and adjusted in accordance with the results of instrumental examinations. The maximum allowable values of parameter $\Pi_{\max }$ shall ensure an opportunity for conducting measures directed on maintaining the serviceability of buildings.

At that $\mathrm{T}_{\text {мон.max }}$ (Fig. 2) is the maximum allowable duration of the examination period which should ensure detection of the onset of damages in proper time before the date after which the renewal of the design operating conditions will become impossible. The maximum duration of this term shall be specified on the basis of the maximum deviation of parameter $\Delta \Pi_{\mathrm{B}}$ which may be determined at the specified measurement error $\sigma_{\mathrm{B}}$ that shall comply with the relation $\sigma_{\mathrm{B}} \geq 0,2 \Delta \Pi_{\mathrm{B}}$. In such a case the monitoring will ensure timely detection of parameter deviation at the specified inaccuracy of the measuring system

$$
\mathrm{T}_{\text {мон. } \max }=\Delta \Pi_{\mathrm{B}} / \mathrm{V}=5 \sigma_{\mathrm{B}} / \mathrm{V}
$$




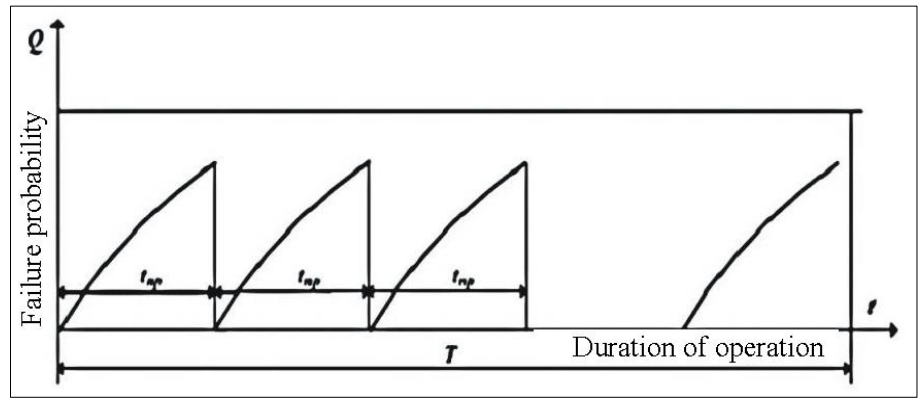

Fig. 1. Curve of changes in failure probabilities:

$t_{n p}$ - time of renewal of functional qualities

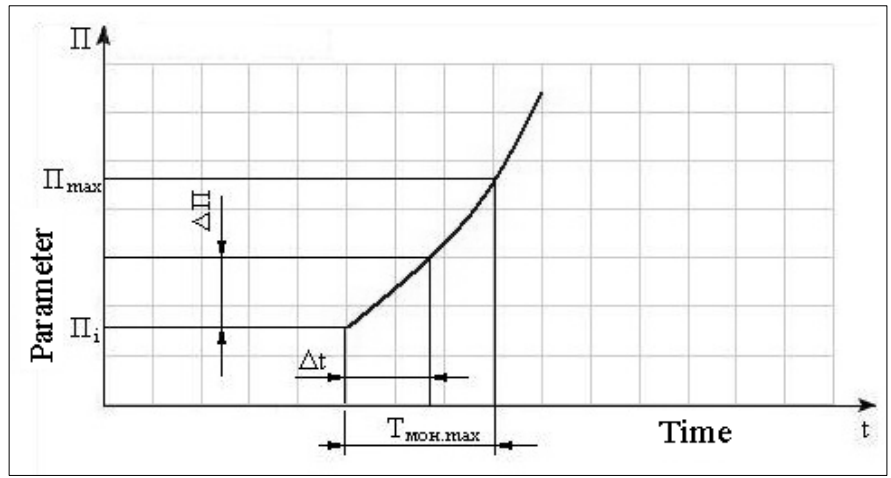

Fig. 2. Determination of the maximum period of instrumental examinations

\section{Periodicity of examinations subject to the terms of repair and restoration work}

The greatest number of accidents occurs within the first 10-15 years of operation. During these accidents design and work performance errors are detected. According to the statistic data more than $32 \%$ of accidents occur at facilities whose term of operation does not exceed 10 years (Fig. 3). Percentage of accidents at buildings and structures of more than 40 years old is less than this indicator for "younger" structures by a factor of six. Then, until the 70-year term of operation a period of relatively even distribution of structure life-limiting failures lasts. The causes of failures are design or work performance errors, application of ineffective materials due to increased costs and profits. 
Taking into account the great number of accidents during the initial stage of operation of structures let's apply the following expression that describes the time behavior of deterioration to determine the terms of repair and restoration work

$$
3=\lambda \sqrt{\mathrm{t}}
$$

where 3 is the building deterioration, \%;

$\lambda$ is the coefficient that characterizes the rate of deterioration;

$\mathrm{t}$ is the service lifetime, years.

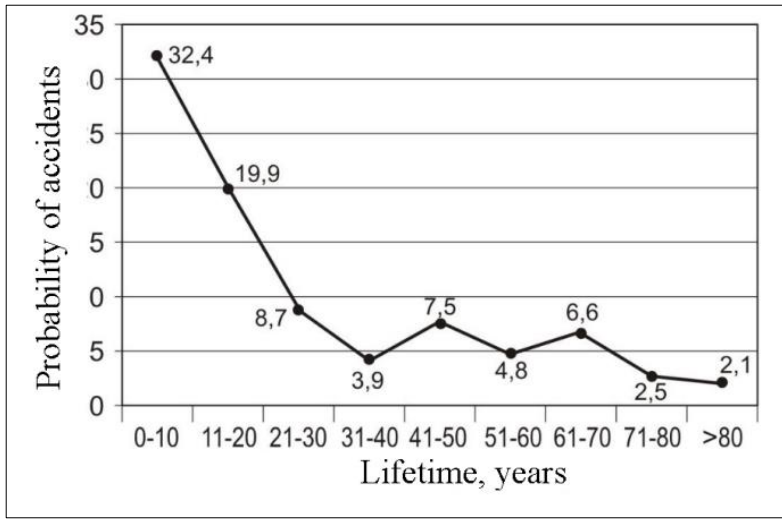

Fig. 3. Accidents with buildings against their lifetime

For buildings with the standard lifetime of 100 years let's assume the value of deterioration as $100 \%$. In this case the coefficient is

$$
\lambda=\sqrt{\frac{3^{2}}{\mathrm{t}}}=0,1
$$

Figure 4 shows the time behavior of building deterioration for such data. For this function the rate of deterioration at the initial stage of operation is defined as the first derivative of the function

$$
\mathrm{I}=\frac{\mathrm{d} 3}{\mathrm{dt}}=\frac{\lambda}{2 \sqrt{\mathrm{t}}}
$$


The plot of the first derivative is shown in Fig. 5. According to the plot the rate of deterioration at the initial stage of operation exceeds this indicator for the period of overhaul after 24 years by a factor of about 5 that corresponds with the statistic data on accident rates of buildings (see Fig. 3). On the basis of the assumption that at the deterioration of $41 \%$ the buildings are considered as unserviceable we can determine the execution period for overhauls $T_{к р}$ (Fig. 4). At the overhaul execution period of $T_{\mathrm{kp}}=16$ years and the service lifetime of $T_{e}=100$ years the number of overhauls is

$$
\mathrm{n}_{\text {кр }}=\frac{\mathrm{T}_{\mathrm{e}}}{\mathrm{T}_{\text {кр }}}=\frac{100}{16}=6,25 .
$$

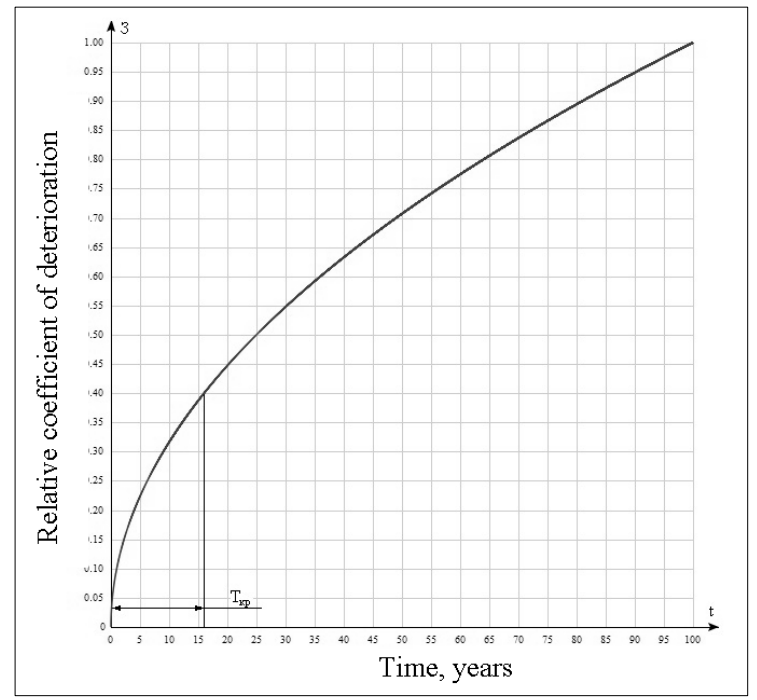

Fig. 4. Plot of building deterioration against time

Let's assume $\mathrm{n}_{\mathrm{кр}}=6$ for the whole period of lifetime and the residual building deterioration of $3_{3}=2,5 \%$ during overhaul. The dependence of building deterioration against time at the periods of overhaul is shown in Fig. 6 where the reduced building deterioration during the overhauls is taken into consideration and the overhaul periods are grouped by similar service lives of structures and conducted every 3-5 years. The data on the dependence of the terms of overhauls against the service lives are presented in Table 1. 
Table 1

Terms of overhauls

\begin{tabular}{|c|c|c|c|}
\hline $\begin{array}{c}\text { Standard service } \\
\text { lifetime, years }\end{array}$ & $\mathbf{1 0 0}$ & $\mathbf{6 0}$ & $\mathbf{5 0}$ \\
\hline$\lambda$ & 0,1 & 0,129 & 0,141 \\
\hline$T_{\kappa n . m i n}$, years & 16 & 10 & 8 \\
\hline \multicolumn{4}{|c|}{ Note: $T_{\kappa n}$ is the term of overhaul $(3=40 \%)$} \\
\hline
\end{tabular}

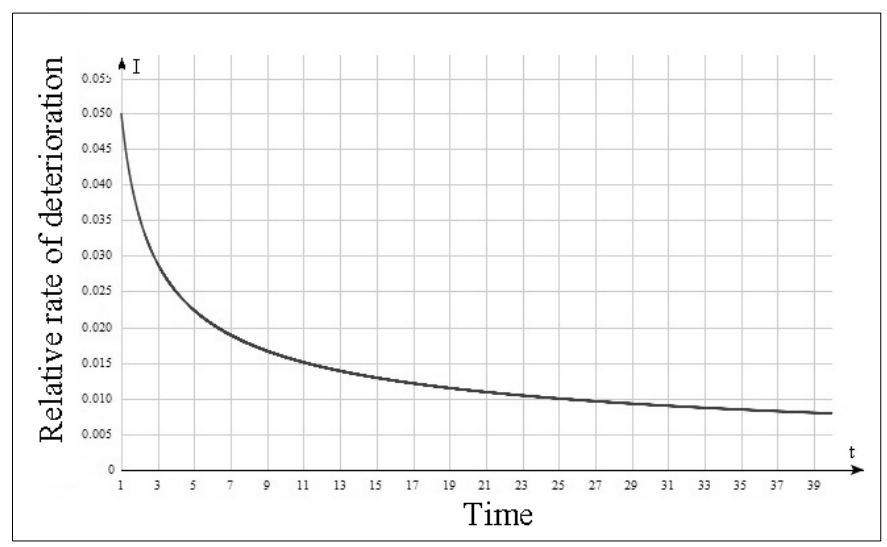

Fig. 5. Rate of deterioration vs. time

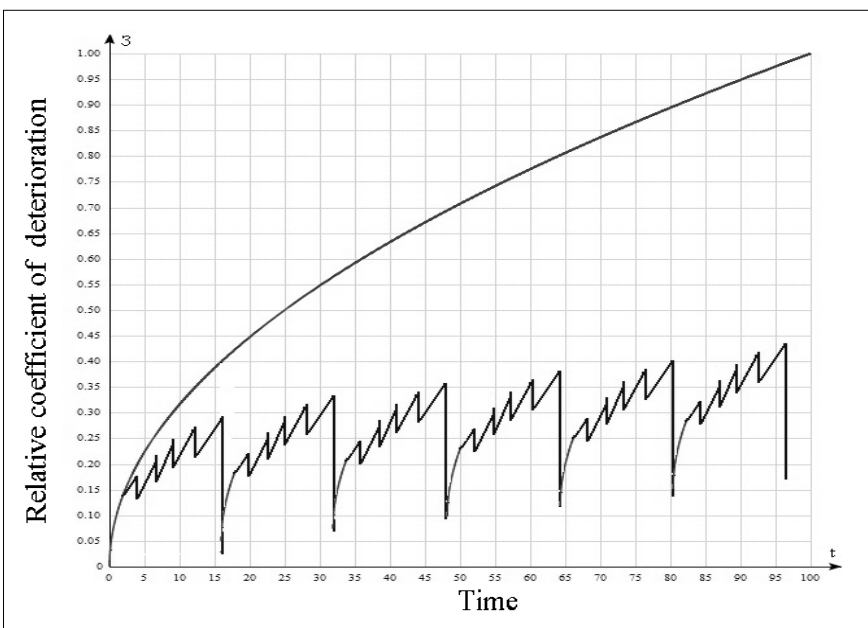

Fig. 6. Building deterioration vs. time during overhauls 
The method does not account for the level of building safety that is characterized by reliability, environmental safety and effects of corrosive environment. Nevertheless the application of coefficient $K_{\sigma}$ (2) for correction of the term of examination $T_{k n \text { min }}$ will allow accounting these factors as well

$$
\mathrm{T}_{\text {кр }}=\mathrm{T}_{\text {кп. min }} \cdot \mathrm{K}_{\text {б }}
$$

As repair operations are always performed after the examinations whose purpose is a determination of a scope of such operations the method used for determination of the terms of building repairs may be applied for defining the terms of instrumental examinations.

\section{Periodicity of settlement control operations at the initial stage of building life cycle and in the process of operation}

In establishing the periodicity of examinations the additional information about the processes of development of settlements at the initial stage of the building life cycle may be used as for various types of soil the processes of settlement have been well studied and predicted. The use of the process of settlement for establishing the periodicity of examinations does not mean that only settlements are measured during such examinations. The scope and quality of examinations shall be defined in the project and operating documentation with accounting for the technical and economic performance indices. In controlling a variable parameter with a certain periodicity it is necessary to compare the measurements with the specified design or standard values and make the corresponding conclusions for adopting decisions.

Theoretical studies and experience in conducting examinations indicate that the rate of and time for stabilization of the deformation processes in buildings and structures may be varied over a wide range and substantially related with the processes of soil consolidation. The recommendations in the current normative documents on establishing the periodicity of examinations are very fuzzy and not related to the characteristics of base soils. In arranging the process of deformation control this fact may be a cause of fatal errors and affect the validity of obtained data or result in increased costs of the measuring operations.

Curves of relative subsidence and periods of its stabilization for various soil types are shown in Figure 7 and data on duration of the process of active 
subsidence and deformations are presented in Table 2 (according to the works $^{4,5}$ ).
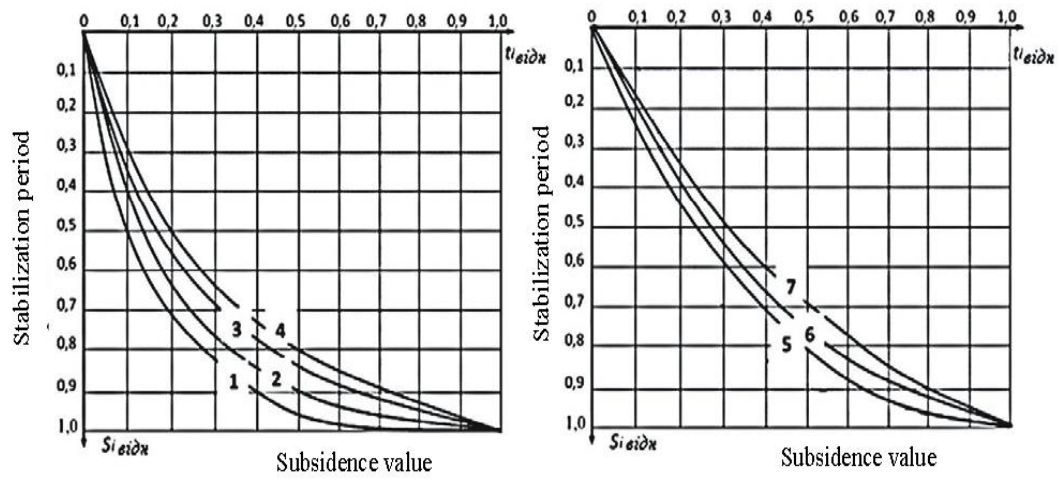

Fig. 7. Curves of relative subsidence:

1 - on gravel and coarse sands; 2 - on medium coarse sands;

3 - on fine sands; 4 - on silt soils; 5 - on sandy soils; 6 - on sandy clays;

7 - on clays; $S_{i \text { вidн. }}$ is the relative value of subsidence;

$t_{\text {ввідн. }}$ is the relative stabilization period of subsidence

Table 2

\section{Duration of active process of subsidence and deformations} (until process stabilization)

\begin{tabular}{|c|c|c|}
\hline Controlled parameters & Types of base soils & Duration $\mathrm{T}_{\text {п }}$, years \\
\hline \multirow{4}{*}{ Absolute subsidence, relative } & Gravel and coarse sands & 1 \\
\cline { 2 - 3 } difference of subsidence sizes, tilt, & Medium coarse sands & 1,5 \\
\cline { 2 - 3 } deflection of structures, buildings & Fine sands & 2 \\
\cline { 2 - 3 } and constructions due to static loads & Silt sands & 3 \\
\cline { 2 - 3 } & Sandy soils & 4 \\
\cline { 2 - 3 } & Candy clays & 10 \\
\hline
\end{tabular}

${ }^{4}$ SBC V.1.2-14-2009.Reliability and safety of building facilities assurance system. General principles of assurance of reliability and structural safety of buildings, structures, building constructions and bases. - [Enforced on 2009-12-01]. - K.: Minregionbud of Ukraine, 2009. - 44 p. - (State Building Code of Ukraine) (in Ukrainian).

5 Zhukov B.N. Manual of geodetic control of structures and equipment of industrial enterprises during their operation / B.N. Zhukov. - Novosibirsk: SGGA, 2003. - 376 p. (in Russian). 
The curves of relative subsidence may be defined by formula

$$
\mathrm{S}_{\mathrm{t}} / \mathrm{S}_{\mathrm{r}}=\left(1-\mathrm{e}^{-\mathrm{N} \cdot \mathrm{t}}\right)
$$

where $\mathrm{N}$ is the coefficient that allows for impervious blanket thickness, characteristic of relative soil compressibility and soil permeability;

$\mathrm{t}$ is time;

$\mathrm{e}$ is the natural logarithm base;

$\mathrm{S}_{\mathrm{r}}$ is the allowable limit value of deformation.

The relative subsidence rate is defined as the first derivative of the function (11)

$$
\mathrm{V}_{\mathrm{B}}=\mathrm{d} / \mathrm{dt}\left(\mathrm{S}_{\mathrm{t}} / \mathrm{S}_{\mathrm{r}}\right)=\mathrm{Ne}^{-\mathrm{Nt}}
$$

The initial rate of subsidence was used to calculate a period of instrumental examinations. This will allow us not to miss a change in parameters. At $t=0 \quad V_{B}=N$, that is the numerical value of the relative rate of subsidence equals the coefficient $\mathrm{N}$.

When the characteristics of relative soil compressibility $\mathrm{N}$ are not known and only the soil types are known the value of $\mathrm{N}$ may be determined with the use of the curves for various soil types. For this purpose for the specified time $\mathrm{t}=0,3$ the value $\mathrm{S}_{\mathrm{t}} / \mathrm{S}_{\mathrm{r}}$ shall be determined with the curves and the coefficient $\mathrm{N}$ shall be calculated by the formula. The calculated coefficients $\mathrm{N}$ for various soil types are summarized in Table 3 .

Table 3

Coefficient characterizing the capability of soils to be compressed

\begin{tabular}{|c|c|c|c|c|c|c|c|}
\hline Soil type according to Fig. $\mathbf{7}$ & $\mathbf{1}$ & $\mathbf{2}$ & $\mathbf{3}$ & $\mathbf{4}$ & $\mathbf{5}$ & $\mathbf{6}$ & $\mathbf{7}$ \\
\hline $\mathrm{N}$ & 5,71 & 4,89 & 3,80 & 3,41 & 2,89 & 2,59 & 2,18 \\
\hline
\end{tabular}


Limit deformations of bases

\begin{tabular}{|c|c|c|c|}
\hline \multirow[b]{2}{*}{ Structures } & \multicolumn{3}{|c|}{ Limit deformations } \\
\hline & $\begin{array}{c}\text { Relative difference } \\
\text { of subsidence sizes } \\
\qquad(\Delta s / L)_{u}\end{array}$ & $\begin{array}{c}\text { Tilt } \\
i_{u}\end{array}$ & $\begin{array}{c}\text { Limit } \\
\text { subsidence } \\
\mathrm{S}_{\max }, \mathbf{c m} \\
\end{array}$ \\
\hline \multicolumn{4}{|c|}{ 1. Industrial and civil single storey and multistorey buildings with full frameworks of: } \\
\hline reinforced concrete & 0,002 & - & $(10)$ \\
\hline $\begin{array}{l}\text { the same with installation of reinforced concrete } \\
\text { belts or solid floors and buildings with solid } \\
\text { structures }\end{array}$ & 0,003 & - & $(15)$ \\
\hline steel & 0,004 & - & $(15)$ \\
\hline $\begin{array}{l}\text { the same with installation of reinforced concrete } \\
\text { belts or solid floors }\end{array}$ & 0,005 & - & (18) \\
\hline $\begin{array}{l}\text { 2. Buildings and structures whose structural } \\
\text { members are not affected by loads due to non- } \\
\text { uniform subsidence }\end{array}$ & 0,006 & - & $(20)$ \\
\hline \multicolumn{4}{|c|}{ 3. Multistorey frameless buildings with bearing walls of: } \\
\hline large panels & 0,0016 & 0,005 & 12 \\
\hline $\begin{array}{l}\text { large blocks or brickwork without } \\
\text { reinforcement }\end{array}$ & 0,0020 & 0,005 & 12 \\
\hline the same with reinforcement & 0,0024 & 0,005 & 18 \\
\hline
\end{tabular}

Then we need to know an absolute rate of subsidence which depends on a duration of the process of active subsidence (Table 2) and a maximum allowable value of deformations (Tables 4 and 5) ${ }^{6,7}$.

At that the subsidence rate for a multistorey frameless building with bearing walls of large panels which is located on sandy soil equals

$$
\mathrm{V}=\mathrm{V}_{\mathrm{B}} \cdot \frac{\mathrm{S}_{\max }}{\mathrm{T}_{\text {п }}}=2,89 \frac{120}{4 \cdot 365}=0,237(\mathrm{~mm} / \mathrm{day})
$$

Since

$$
\mathrm{T}_{\text {мон. } \max }=5 \sigma_{\mathrm{в}} / \mathrm{V},
$$

${ }^{6}$ SBC V.2.1-10-2009. Construction facilities and industrial products for construction work. Bases and foundations of buildings and structures. Bases and foundations of structures. [Enforced on 2009-07-01]. - K.: Minregionbud of Ukraine, 2009. - 82 p. - (State Building Code of Ukraine) (in Ukrainian)

${ }^{7}$ DSTU B V.1.2-3:2006. Reliability and safety assurance system of construction facilities. Deflections and displacements. Design requirements. - [Enforced on 2007-01-01]. - K.: Minbud of Ukraine, 2006. - 30 p. - (National Standard of Ukraine) (in Ukrainian). 
and assuming $\sigma_{\mathrm{B}}=0,5 \mathrm{~mm}$, we obtain

$$
\mathrm{T}_{\text {мон } \max }=5 \cdot 0,5 / 0,237=10,5 \text {. }
$$

Let us assume that

$$
\mathrm{T}_{\text {мон. } \max }=10 \text { days. }
$$

The proposed method can be applied not only for defining the period of building subsidence stabilization. It allows: obtaining rather reliable characteristics of active subsidence processes, horizontal displacements and deformations; optimization of the number of measuring cycles as compared with the recommendations of the current normative documents to ensure that any changes in the geometrical parameters of building will not be missed and determination of the period of examinations for monitoring subsidence sizes, tilts and displacements with the use of equation (1) and data listed in Tables 2 and 4.

According to the recommendations, during construction under the conditions of dense development areas with existing buildings (as a rule these are the historic development areas with historical, cultural or architectural monuments) their additional deformations due to a new construction shall not exceed the limit values presented in Table 6. With the use of the data of this table a period of examinations for monitoring subsidence sizes and tilts of buildings located in the dense development areas may be determined.

Table 5

Horizontal limit displacements

\begin{tabular}{|l|c|}
\hline \multicolumn{1}{|c|}{ Buildings, walls and partitions } & $\begin{array}{c}\text { Limit } \\
\text { displacement } f_{u}\end{array}$ \\
\hline 1 Multistorey buildings & $h / 500$ \\
\hline 2 Single floor in a multistorey building: & $h_{s} / 300$ \\
\hline $\begin{array}{l}\text { a) walls and partitions made of bricks, gypsum plasterboard, } \\
\text { reinforced concrete panels }\end{array}$ & $h_{s} / 500$ \\
\hline $\begin{array}{l}\text { b) walls lined with natural stone or made of ceramic blocks } \\
\text { or glass (stained-glass) }\end{array}$ & $h_{s} / 700$ \\
\hline 3 Single storey buildings with a ceiling height $h_{s}, \mathrm{~m}: h_{s} \leq 6$ & $h_{s} / 150$ \\
$h_{s}=15$ & $h_{s} / 200$ \\
$h_{s} \geq 30$ & $h_{s} / 300$ \\
\hline
\end{tabular}


Table 6

Limit values of additional deformations

\begin{tabular}{|c|c|c|c|c|}
\hline \multirow[b]{2}{*}{ Structures } & \multirow[b]{2}{*}{$\begin{array}{c}\text { Category } \\
\text { of state }\end{array}$} & \multicolumn{3}{|c|}{ Limit deformations } \\
\hline & & $\begin{array}{c}\text { Relative } \\
\text { difference of } \\
\text { subsidence sizes } \\
(\Delta s / L)_{u} \\
\end{array}$ & Tilt $i_{u}$ & $\begin{array}{c}\text { Limit } \\
\text { subsidence } \\
\mathrm{S}_{\max }, \mathbf{c m}\end{array}$ \\
\hline \multirow{4}{*}{$\begin{array}{l}\text { Multistorey frameless buildings made } \\
\text { of large blocks or brickwork without } \\
\text { reinforcement. }\end{array}$} & I & $2 \times 10^{-3}$ & $2 \times 10^{-3}$ & 4,0 \\
\hline & II & $1 \times 10^{-3}$ & $1 \times 10^{-3}$ & 3,0 \\
\hline & III & $7 \times 10^{-4}$ & $7 \times 10^{-4}$ & 1,0 \\
\hline & IV & $4 \times 10^{-4}$ & $4 \times 10^{-4}$ & 0,4 \\
\hline \multirow{4}{*}{$\begin{array}{l}\text { Multistorey and single-storey buildings } \\
\text { of historic development or monuments } \\
\text { with bearing walls made of brickwork } \\
\text { without reinforcement. }\end{array}$} & $\mathrm{I}$ & - & - & - \\
\hline & II & $6 \times 10^{-4}$ & $6 \times 10^{-4}$ & 1,0 \\
\hline & III & $4 \times 10^{-4}$ & $4 \times 10^{-4}$ & 0,4 \\
\hline & IV & $1 \times 10^{-4}$ & $1 \times 10^{-4}$ & 0,2 \\
\hline
\end{tabular}

\section{Periodicity of ground water level control}

By the nature of underflooding all development areas are divided into natural or man-caused flood-prone areas and non-flood-prone areas which, in their turn, are divided by a degree of process development into potentially flood-prone or flood-prone territories and territories that demand obligatory protection. The potentially flood-prone territories are plots that are disposed to be underflooded, at which the raised level of ground water has caused or can cause the predictable worsening of serviceability of building facilities or occurrence of emergencies.

The flood-prone territories are divided by development stages of this process into:

- flood-prone territories within the plots at which the level of ground water is permanently or temporary (excluding accidental emergencies) above a limit depth or the raised level of ground water significantly worsens the serviceability of building facilities;

- flood-prone territories that demand an urgent protection of plots where an emergency has occurred due to the raised level of ground water (underflooding) and its consequences or where unsafe for health and environment conditions have been generated.

The limit depth of occurrence of ground water is an allowable maximum (according to predictions) level of ground water over the whole period of operation of the territory with buildings and structures. In designing possible changes in hydrogeological conditions at the site during construction and operation of a facility shall be accounted for. Such changes may be a result of both natural and man-caused effects. In the first case these are natural seasonal perennial variations of the level of ground water. In the second case the man-caused changes in the ground water level as well as a degree of corrosiveness of soil and their corrosive activity are possible. Possible 
changes in the ground water level in the development territory are estimated on the basis of the engineering survey data with accounting for new regimeforming factors that change a structure of water balance in the territory and are additional man-caused loads on geological environment. Figure 8 shows a classification of basic man-caused changes in the water regime and their consequences on the basis of the principle of possibility of their detection by instrumental methods.

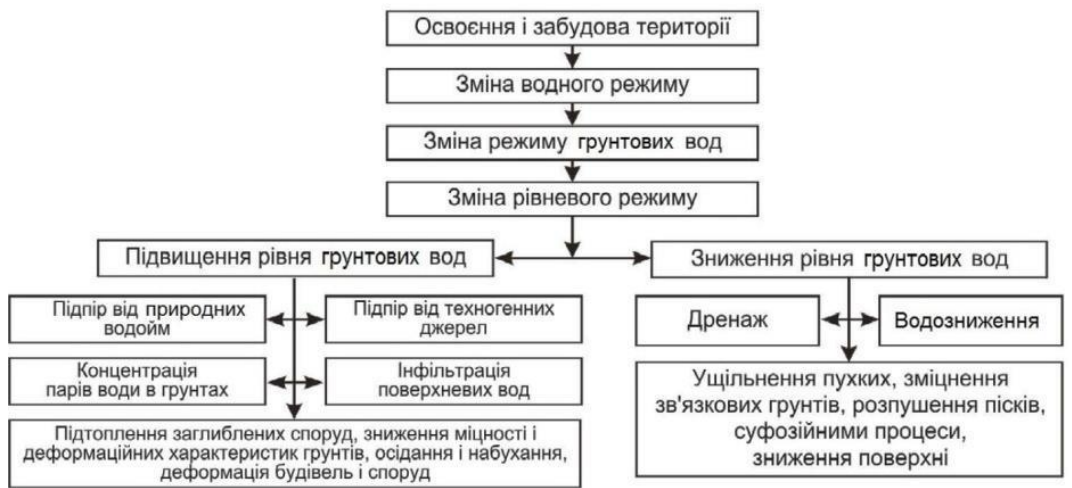

\section{Fig. 8. Classification of basic man-caused changes of the water regime and their consequences}

In the potentially non-flood-prone territories any significant raising of soil wetness and the ground water level (GWL) is not observed owing to availability of well-permeable soils or relatively deep position of the ground water level and favorable man-caused conditions (insignificant barrage effect, lack of moistureproducing businesses, small leakages from utilities etc.).

The process of underflooding development has two periods:

- during the first period the ground water level raises or soil wetness increases; such processes have no practical effect on the serviceability of structure that is the critical values of the ground water level (Нкр) and soil wetness (Wкр) are not still attained;

- the second period is characterized by the attained critical values Нкр and Wкр and the negative effect of underflooding on soils in bases and substructures of buildings and structures.

The rate of potential underflooding is based on the following preconditions:

- industrial businesses are classified by specific consumption of water according to their 'wet' or 'dry' processes; 
- on the basis of available data on underflooded development territories all types of soil conditions are classified according to four schemes based on the types of geological sections (Table 7).

The tendency to potential underflooding of territory is estimated by the criterion of potential underflooding

$$
\mathrm{P}=\left(\mathrm{h}_{\mathrm{e}}-\Delta \mathrm{h}\right) / \mathrm{H}_{\mathrm{\kappa p}},
$$

where $h_{e}$ is the ground water level before the occurrence of underflooding, it shall be defined according to the data of engineering survey (measured from the ground) $\mathrm{m}$;

$\Delta \mathrm{h}$ is the value of predicted raise of ground water at the specified point, it shall be defined according to data of Table 7, m;

$\mathrm{H}_{\text {кр }}$ is the critical ground water level measured from the ground.

At $\mathrm{P} \leq 1$ and $\mathrm{t}_{\mathrm{kp}} \leq \mathrm{T}_{\text {розр. }}$; $\mathrm{t}_{\mathrm{кр}}$ is the period of time for occurrence of the critical level $\mathrm{H}_{\mathrm{kp}}$ ) the territory is potentially flood-prone; at $t_{\mathrm{kp}}>\mathrm{T}_{\text {розр. }}$ it is potentially non-flood prone. The time is an indirect indicator of the rate of potential underflooding of territory and under condition that $P=1$ it is defined as $\Delta \mathrm{h}=\mathrm{h}_{\mathrm{e}}-\mathrm{H}_{\mathrm{kp}}$

Table 7

Classification of territories by hydrological zones

\begin{tabular}{|c|c|c|c|c|}
\hline $\begin{array}{c}\text { Scheme of } \\
\text { natural } \\
\text { conditions }\end{array}$ & Typical lythologic sections & $\begin{array}{c}\text { Thickness } \\
\text { of layer, } \\
\text { m }\end{array}$ & $\begin{array}{l}\text { Depth of } \\
\text { GWL, m }\end{array}$ & $\begin{array}{l}\text { Hydrological zone } \\
\text { of Ukraine }\end{array}$ \\
\hline . & $\begin{array}{c}\text { Layer } 1 \text { - loess loams and } \\
\text { sagging sandy soils. } \\
\text { Layer } 2 \text { - (water-tight stratum) } \\
\text { - clays, sandstones etc. }\end{array}$ & Up to 25 & 15 to 25 & $\begin{array}{l}\text { Zone of periodical } \\
\text { moistening, all territory }\end{array}$ \\
\hline 2 & $\begin{array}{c}\text { Layer } 1 \text { - sandy soils, loams } \\
\text { and alluvial-glacial sands. } \\
\text { Layer } 2 \text { - (water-tight stratum) } \\
\text { - clays, moraine clays. }\end{array}$ & Up to 15 & Up to 10 & $\begin{array}{l}\text { Zone of overmoistening, } \\
\text { the most part }\end{array}$ \\
\hline 3 & $\begin{array}{c}\text { Layer } 1 \text { - sandy clays and } \\
\text { blanket sandy soils of low } \\
\text { thickness. } \\
\text { Layer } 2 \text { - (water-tight stratum) } \\
\text { - expansive clays. }\end{array}$ & 1 to 5 & $\begin{array}{l}\text { More } \\
\text { than } 15\end{array}$ & $\begin{array}{l}\text { Zone of insufficient and } \\
\text { mixed periodical } \\
\text { moistening, eastern and } \\
\text { southern territories }\end{array}$ \\
\hline 4 & $\begin{array}{c}\text { Layer } 1 \text { - sandy clays, sandy } \\
\text { loam and silt, fine, coarse } \\
\text { sands, pebble stones. } \\
\text { Layer } 2-\text { (water-tight stratum) } \\
\text { - bedrocks of various } \\
\text { formations. } \\
\end{array}$ & Up to 10 & 5 to 10 & $\begin{array}{l}\text { Zone of periodical } \\
\text { moistening, the most part } \\
\text { of territory }\end{array}$ \\
\hline
\end{tabular}


Table 8 shows the rates of raising of the ground water level (GWL) therefore the value $t_{к р}$ is determined ${ }^{1}$ by relation

$$
\mathrm{t}_{\mathrm{kp}}=\Delta \mathrm{h} / \mathrm{V}
$$

Taking $t_{\mathrm{кp}}$ into account the degree of tendency to potential underflooding is specified:

- for the structures of Class I the first degree of tendency to potential underflooding (the most unsafe) - underflooding will occur within 5 years; the second degree - within 10 years; the third degree - within 15 yrs; the fourth degree - within $20 \mathrm{yrs}$; and the fifth - within 25 years.

- for the structures of Class II only the first three degrees of tendency to potential underflooding are applied.

Table 8

Types of flood-prone building facilities

\begin{tabular}{|c|c|c|c|c|c|}
\hline \multirow[b]{2}{*}{$\begin{array}{c}\text { Type of } \\
\text { underflooding }\end{array}$} & \multirow[b]{2}{*}{$\begin{array}{l}\text { Scheme of } \\
\text { natural } \\
\text { conditions }\end{array}$} & \multicolumn{4}{|c|}{ Rate of raising of ground water } \\
\hline & & $\begin{array}{l}\text { Within the } \\
\text { first } 10 \\
\text { years, } \\
\text { m/year }\end{array}$ & $\begin{array}{c}\text { Within } \\
10 \text { to } 15 \\
\text { years, } \\
\text { m/year }\end{array}$ & $\begin{array}{c}\text { Within } \\
15 \text { to } 20 \\
\text { years, } \\
\text { m/year }\end{array}$ & \begin{tabular}{|c|} 
Within \\
20 to 25 \\
years, $\mathrm{m} /$ year
\end{tabular} \\
\hline I & $\begin{array}{l}1 \\
2 \\
3 \\
\end{array}$ & 0,5 to 1 & 0,25 to 0,5 & $\begin{array}{l}0,3 \text { to } 0,6 \\
0,2 \text { to } 0,4\end{array}$ & 0,15 to 0,3 \\
\hline II & $\begin{array}{l}1 \\
2 \\
4 \\
\end{array}$ & 0,3 to 0,5 & 0,1 to 0,2 & 0,1 to 0,15 & 0,08 to 0,13 \\
\hline III & $\begin{array}{l}1 \\
2 \\
3 \\
4\end{array}$ & 0,1 to 0,3 & 0,03 to 0,1 & $\begin{array}{c}0,025 \text { to } \\
0,008\end{array}$ & 0,02 to 0,06 \\
\hline
\end{tabular}

That is, the potential underflooding of the developed territory is estimated; the quantitative estimates are made for corresponding structures when the prediction of changes in the ground water level subject to mancaused effects is made on the basis of comprehensive special studies which include an annual cycle of stationary examinations of the ground water regime.

The period of instrumental examinations of the ground water level may be defined as

$$
\mathrm{t}_{\text {мон }}=\Delta \mathrm{h}_{\mathrm{T}} / \mathrm{V}_{\max },
$$


where $\Delta \mathrm{h}_{\mathrm{T}}$ is the change in the ground water level within an accuracy of measuring devices;

$\mathrm{V}_{\max }$ is the maximum rate of raising of the ground water, $\mathrm{m} / \mathrm{year}$.

The data on period of examinations for various conditions at $\Delta \mathrm{h}_{\mathrm{T}}=2 \mathrm{~cm}$ are shown in Table 9.

Table 9

Minimum period of instrumental examinations

for various types of underflooding

\begin{tabular}{|c|c|c|c|c|}
\hline \multirow{2}{*}{$\begin{array}{c}\text { Type } \\
\text { of underflooding }\end{array}$} & \multicolumn{4}{|c|}{ Period of examinations, days } \\
\cline { 2 - 5 } & For the first 10 years & $\mathbf{1 0}$ to 15 years & $\mathbf{1 5}$ to 20 year & $\mathbf{2 0}$ to 25 years \\
\hline I & 7 & 15 & 18 & 24 \\
\hline II & 15 & 36 & 49 & 56 \\
\hline III & 24 & 73 & 91 & 122 \\
\hline
\end{tabular}

\section{Periodicity of slide control}

The following basic types of slides are defined: flow, escape, upfloat, coming out, subsiding, rarefying. In the development areas the most prevalent types are flow slides and escape slides. Slides within the areas of development and economic activities result in negative consequences. Table 10 shows the data on probabilities of slide occurrences and measures to be performed in the slide-affected area subject to the compliance of structures with requirements.

Table 10

Level of slide occurrence probability

\begin{tabular}{|c|c|c|c|}
\hline \multirow{2}{*}{ Construction facilities } & \multicolumn{3}{|c|}{$\begin{array}{l}\text { Level of risk of slide occurrence that demands decisions } \\
\text { on taking necessary measures }\end{array}$} \\
\hline & $\begin{array}{c}\text { protection of } \\
\text { structures }\end{array}$ & $\begin{array}{l}\text { protection of structures } \\
\text { or monitoring of slopes }\end{array}$ & $\begin{array}{c}\text { monitoring } \\
\text { of slopes }\end{array}$ \\
\hline $\begin{array}{l}\text { Large-scale construction } \\
\text { facilities }\end{array}$ & $>10 \%$ & - & 5 to $10 \%$ \\
\hline $\begin{array}{l}\text { Facilities of increased } \\
\text { importance }\end{array}$ & $>5 \%$ & 5 to $10 \%$ & 1 to $5 \%$ \\
\hline Very important facilities & $>1 \%$ & 1 to $5 \%$ & 0 to $1 \%$ \\
\hline
\end{tabular}

Slopes are considered stable if the stability factor $\mathrm{K}_{\mathrm{c}} \succ 1$. The value $\mathrm{K}_{\mathrm{c}}=1$ corresponds to the limit equilibrium. When buildings are located on a slope the slope stability factor shall comply with requirements

$$
\mathrm{K}_{\mathrm{c}} \geq \mathrm{K}_{\mathrm{c.доп}},
$$


where $K_{c . \partial o n}$ is the allowable value of stability factor which shall be defined at the design stage subject to loads, reliability and operating conditions.

In areas where slides are possible and the stability factor complies with the requirement $\mathrm{K}_{\mathrm{c}}>1$, the following shall be under monitoring: horizontal displacements, the ground water level and pore pressure. Periodicity of horizontal displacement control may be found from relation (13). For flow slide the maximum velocity of sliding is defined by the following formula ${ }^{8}$

$$
\mathrm{V}_{\mathrm{c}}^{\max }=\frac{\rho \cdot \mathrm{g} \cdot \mathrm{H}^{2} \cdot \sin \alpha}{2 \cdot \mu},
$$

where $\rho$ is the soil density, $\mathrm{t} / \mathrm{m}^{3}$;

$H$ is the maximum thickness of the sliding soil mass, m;

$\alpha$ is the angle of sliding surface, degree;

$\mu$ is the soil viscosity.

The average velocity value across the whole section is given by formula

$$
\mathrm{V}_{\mathrm{c}}^{\mathrm{cp}}=\frac{2}{3} \cdot \mathrm{V}_{\mathrm{c}}^{\max }
$$

The recommended approximate periods of examinations of slopes for various slide types at various values of the stability factor which have been determined on the basis of the data of earlier examinations are shown in Table 11.

Table 11

\section{Recommended approximate periods of monitoring of slopes}

\begin{tabular}{|c|c|c|}
\hline \multirow{2}{*}{$\begin{array}{c}\text { Slope stability } \\
\text { factor }\end{array}$} & \multicolumn{2}{|c|}{ Periodicity of monitoring, days } \\
\cline { 2 - 3 } & Forms of stability disturbances and slope deformations (slide types) \\
\cline { 2 - 3 } & escape & flow \\
\hline 0,7 & 7 & 10 \\
\hline 0,8 & 12 & 18 \\
\hline 0,9 & 20 & 25 \\
\hline 1,0 & 40 & 60 \\
\hline 1,1 & 60 & 100 \\
\hline 1,2 & 180 & 300 \\
\hline 1,35 & 360 & 500 \\
\hline
\end{tabular}

${ }^{8}$ Bugrov A.K. Determination of probability characteristics of soil active pressure by the Monte Carlo method [Electronic resource] / A.K. Bugrov, V.G. Shilin // Internet journal «Reconstruction of towns and geotechnical construction». - 2002. - No. 5. - Access mode: http://www.qeorec.spb.ru/maq/2002n5/index.htm. (10.10.14). - Title from a screen (in Russian). 
Since saturation of soil mass by water is a main cause of slides the monitoring of pore water pressure is necessary. In the process of design work a possible rate of pore pressure variations shall be determined. Selection of measuring means is carried out with accounting for a range of possible pressure variations and required accuracy of measurements.

Periodicity of pore pressure control may be defined as follows

$$
\mathrm{T}_{\text {мон.пор.тс }}=\Delta_{\mathrm{\mu}} / \mathrm{V}_{\text {п.в }} \text {, }
$$

where $\Delta_{д}$ is the resolving power of a pore pressure sensor;

$\mathrm{V}_{\text {п.в }}$ is the possible rate of pore pressure variations that is defined at the design stage.

\section{CONCLUSIONS}

1. Methods that may be applied for determination of a periodicity of work on performing instrumental examinations have been studied. It has been established that at present the periodicity of planned examinations is designated by analogy with the buildings which are under average operation conditions, but this method doesn't take into account the conception of class of consequences (the importance of buildings and structures) and may be used only in the period of normal operation.

2. A method of determination of the periodicity of instrumental examinations has been proposed. The method is based on comparison of controlled parameters with the design (predicted) values subject to a range of allowable possible deviations of a controlled parameter. The rate of changes in controlled parameters shall be established during designing work and adjusted as a result of examinations. The maximum allowable values of controlled parameters shall ensure a possibility to take measures for restoration of the building serviceability.

3. A method for adjusting the terms of examinations with accounting for the terms of repair and rehabilitation work has been developed. The function that relates deterioration and time has been applied. This function accounts for a great number of accidents at the initial stage of operation (the power function) as well as the rate of deterioration and the service life when the degree of building deterioration is an impact factor.

4. A method of determination of the periodicity of subsidence control operations at the initial stages of the life cycle of facilities and during their operation has been developed. In determining the periodicity of examinations the information about the process of subsidence development may be used. Studies of the process of subsidence may be used for determination of the periodicity of comprehensive examinations as such a process is an integrated analysis for establishing the categories of facility's 
technical conditions. The quantitative and qualitative aspects of examinations shall be defined in the design and operation documents subject to accounting for technical and economic indices of efficiency.

5. The period of instrumental examinations of the ground water level is established with accounting for a type of underflooding. The classification of basic man-caused changes in the water regime and their consequences has been presented for 4 types of soil conditions which are characterized by a rate of raising of the ground water level. It has been proposed to determine a period of such examinations on the basis of qualitative and quantitative estimates of a tendency to underflooding for the developed territory subject to results of comprehensive studies which comprise at least an annual cycle of stationary instrumental examinations based on predictions of the rate of changes in the ground water level and sensitivity of the measuring devices to dynamics of changes.

6. In regions where slides are possible horizontal displacements and the ground water level shall be controlled. As the presence of ground water is a main cause of land slides in addition to monitoring of horizontal displacements pore water pressure shall be monitored. Measuring devices shall be selected in accordance with the range and rate of possible changes in pore pressure.

\section{SUMMARY}

Methods of determination of the periodicity of work on performing instrumental examinations have been studied. It has been established that at present the periodicity of planned examinations is designated by analogy with the buildings which are under average operation conditions provided that their operating conditions can be maintained until the next planned examination. A method of determination of the periodicity of instrumental examinations that is based on comparison of controlled parameters with the design values has been proposed. The maximum allowable values of controlled parameters shall ensure a possibility to take measures for restoration of the building serviceability. A method for adjusting the terms of examinations with accounting for the terms of repair and rehabilitation work and physical deterioration as a function of time has been developed. The periodicity of subsidence control operations at the initial stages of the life cycle of facilities and during their operation is determined with the use of information about the process of subsidence development. The period of instrumental examinations of the ground water level is established with accounting for a type of underflooding.

It has been proposed to determine a period of such examinations on the basis of qualitative and quantitative estimates of a tendency to underflooding for the developed territory. 


\section{REFERENCES}

1. Ivanyk I.H. Principles of reconstruction of buildings and structures / I.H. Ivanyk, S.I. Vikhot', R.S. Ivannyk, Yu.Yu. Vybranets'; ed. I.H. Ivanyk. - L'viv: Publishers L'viv Politekhnika, 2010. - 276 p. (in Ukrainian).

2. Normative documents on issues of examinations, certifications, safe and reliable operation of production buildings and structures. - K.: NDIBV, 2003. - 144 p. (in Ukrainian).

3. Petrov E.G. Methods and means for making decisions in economic and technical systems / E.G. Petrov, M.V. Novozhilova, I.V. Grebennik, N.A. Sokolova; under the general editorship of E.G. Petrov. - Kherson: OLDI-plus, -2003 . -378 p. (in Russian).

4. SBC V.1.2-14-2009.Reliability and safety of building facilities assurance system. General principles of assurance of reliability and structural safety of buildings, structures, building constructions and bases. [Enforced on 2009-12-01]. - K.: Minregionbud of Ukraine, 2009. - 44 p. (State Building Code of Ukraine) (in Ukrainian).

5. Zhukov B.N. Manual of geodetic control of structures and equipment of industrial enterprises during their operation / B.N. Zhukov. - Novosibirsk: SGGA, 2003. - 376 p. (in Russian).

6. SBC V.2.1-10-2009. Construction facilities and industrial products for construction work. Bases and foundations of buildings and structures. Bases and foundations of structures. - [Enforced on 2009-07-01]. - K.: Minregionbud of Ukraine, 2009. - 82 p. - (State Building Code of Ukraine) (in Ukrainian)

7. DSTU B V.1.2-3:2006. Reliability and safety assurance system of construction facilities. Deflections and displacements. Design requirements. - [Enforced on 2007-01-01]. - K.: Minbud of Ukraine, 2006. - 30 p. - (National Standard of Ukraine) (in Ukrainian).

8. Bugrov A.K. Determination of probability characteristics of soil active pressure by the Monte Carlo method [Electronic resource] / A.K. Bugrov, V.G. Shilin // Internet journal «Reconstruction of towns and geotechnical construction». - 2002. - No. 5. - Access mode: http://www.qeorec.spb.ru/maq/2002n5/index.htm. (10.10.14). - Title from a screen (in Russian).

\section{Information about the author:} Hryhorovskyi P. Ye.,

Doctor of Technical Sciences,

First Deputy Director for Science, State Enterprise 'Research Institute of Building Production named of V.S. Balitsky' (SE 'RIBP') 51, Lobanovskyi ave., Kyiv, 03110, Ukraine 


\title{
STATE CONTROL, IN ACCORDANCE \\ WITH THE INTERNATIONAL PRACTICE, OVER MARKETING OF IMPORTED CONSUMER PRODUCTS
}

\author{
Khyzhniak V. O.
}

\section{INTRODUCTION}

At the current stage of development of the Ukrainian society, when Ukraine has to begin new administrative reforms, considering that Ukraine is ready and willing to be a legally competent member of the European community, the study of the international experience associated with the state control over marketing of imported consumer products is of high priority.

The national policy of Ukraine in the area of the state control of consumer products and of consumer protection is focused on the improvement of existing laws, implementation of European directives, coordination of national standards with international and European standards as normative documents designed for verifying the compliance of products with the specified requirements, arrangement of conditions for activities of enterprises and companies in the area of the state control over marketing of consumer products, and improvement of the existing consumer protection system.

\section{Analysis of recent publications and studies}

The problems in the area of the state control of the safety and quality of consumer products and in the area of consumer protection have been studied by such Ukrainian researches as Mandybura V.O., Zakhozhai V.B., Vitkin L.M., Hryshova I.Y., Prytulska N.V., Yazvinska O.M., Nehodenko V.S., Mytiai O.V., Stoianova-Koval S.S., Malyk M.Y., Paskhaver B.Y., and Sabluk P.T. Nevertheless, there are many existing scientific, organizational, and economic problems in this area which should be studied.

According to the opinion of Vitkin L.M., the elements required for the functioning of an efficient sate control system are the availability of proper legislative and normative acts, allocation of responsibility of controlling institutions, enhanced control of risk-bearing products, availability of incentives for ensuring the safety and quality of products, availability of sufficient information support, and availability of qualified state inspectors. Nevertheless, there is a need to further study the problems associated with 
the state control, according to the international practice, over marketing of imported consumer products.

\section{Study objective}

The study objective is to create, on the basic of the international experience, a modern efficient system for controlling consumer products and providing consumer protection in compliance with the requirements of the Ukrainian economy and consumers and for promoting business activities in Ukraine.

\section{Ukraine}

\section{Study results}

One of the important tasks in reforming the system for controlling consumer products and providing consumer protection according to the international practice is the implementation of a product marketing control system. This system is designed for ensuring the compliance of marketed products with the requirements of standards and normative documents relating to the safety of the products in terms of population health and public interests. Marketing of hazardous products is prevented by implementation, into national legislation, of EU regulations and directives, specifically Regulations No. 765/2008 of July 9, 2008 and Directive 2001/95/EC of December 3, 2001, which relate to the general safety of products, approved by the European Parliament and the European Commission.

The implementation of such normative documents became possible due to the adoption, in 2011, of such laws of Ukraine as the Law on the State Marketing Control and Nonfood Product Control ${ }^{2}$ and the Law on General Safety of Nonfood Products ${ }^{3}$. In accordance with these laws, products which do not comply with the specified requirements or are hazardous for public health are removed from the market. If infringing or faulty products are detected, the corresponding customs and law enforcement authorities should be immediately unformed.

The food product control functions are performed by the newly established State Service on Safety of Food Products and Consumer Protection. The nonfood product control functions are performed by the agencies authorized in accordance with the order of the Cabinet of Ministers of Ukraine on approval of the list of the state product marketing control

${ }^{2}$ Про державний ринковий нагляд і контроль нехарчової продукції; Закон України, 02.12.2010, № 2735-V; zakon.rada.gov.ua/laws/show/2735-17

3 Про загальну безпечність нехарчової продукції; Закон України, 02.12.2010 № 2736-VI; http://zakon.rada.gov.ua/laws/show/2736-17 
agencies and allocation of their responsibility» ${ }^{6}$. At the present time, the state product marketing control in 40 areas of responsibility is provided by 10 control agencies forming an integrated control system.

The product control functions when the products enter the custom territory of Ukraine are performed by customs authorities. If inconsistent products are detected at the border customs station, the corresponding state control agency should be unformed. It should be noted that customs control is mandatory only for such imported nonfood products which are declared as products to be subject to customs control or other control specified for products to be freely marketed in Ukraine ${ }^{7}$.

These factors have different effect on the structure and functions of agencies for performing imported product control in different countries.

\section{United States of America}

The main federal agency for controlling internal trade in USA is the Federal Trade Commission.

The Commission is an independent state authority established in 2014 for performing trade control functions and preventing anticompetitive practice. The Commission also controls the compliance of individuals and legal parties with the federal laws and regulations relating to consumer protection and competition.

The Commission acts on the basis of the Federal Trade Commission Act of 1914 (see Section 15, Items $41 \ldots$ 48, of the USA Federal Code). In accordance with the federal laws and regulations, the Commission has the rule-making powers and the right to use enforcement methods for ensuring the compliance of the internal trade with the requirements of federal laws and regulations concerning internal trade activities, for example, by filing claims to federal jurisdiction courts.

The list of normative documents (about 80 documents) issued by the Commission is presented in Part 1, Section 16, of the Federal Normative Acts Code.

Additionally to administrative functions, the Commission provides consultation services, supports reporting, and renders recommendations and advices for other governmental authorities.

Another independent authority that directly affects internal and external trade activities in USA, is the USA Consumer Product Safety Commission.

${ }^{6}$ Про затвердження переліку органів державного ринкового нагляду та сфер їх відповідальності; Постанова Кабінету Міністрів України, 01.06.2011, № 573; zakon2.rada.gov.ua/laws/show/573-2011-п

7 Віткін Л.М. Вдосконалення державного ринкового нагляду за безпечністю нехарчової продукції відповідно до європейських підходів; Л. Віткін: Стандартизація, сертифікація, якість, 2012, № 5, с. 18-25. 
The Commission protects consumers from hazards possible due to using domestic or foreign consumer products of poor quality. The Commission controls about 15 thousand product names.

According to the Commission estimates, losses induced by such events as illness, injury, or death or by damage of property due to using consumer products of poor quality in USA are about 800 billion dollars per year. The Commission activities in controlling the quality of such nonfood products as toys, fasteners, tools, cigarette lighters, household chemistry products, and other products allow the number of such events to be reduced to 30 percent during the recent 30 years.

The control of imported consumer products in USA is accomplished with consideration for energy saving and handling safety.

With consideration for energy saving, the consumer products are classified as follows:

1. Household appliances

For household appliances, the Energy Policy and Energy Conservation Act specifies applicable standards and regulations related to marking household appliances in connection with energy saving. The Codes and Standards Division of the USA Department of Energy is responsible for testing household appliances for compliance with the specified standards and regulations. The Control Division of the Federal Trade Commission controls marking of household appliances. The aforementioned Act applies to such household appliances as refrigerators, freezers, air conditioners, water heaters, ovens, dishwashers, laundry washers, driers, and other devices.

2. Commercial and industrial equipment

The aforementioned governmental authorities control the certification of commercial and industrial equipment. The categories of such equipment with consideration for handling safety are the following:

a) Toys and other products for children

b) Lead-containing paints

c) Bicycles and helmets for bicyclists

d) Fireworks

e) Combustible textiles

f) Decorative materials

g) Cigarette lighters

h) Other materials and devices

The categories of imported household electronic devices subject to certification are the following:

a) Devices generating electromagnetic or acoustic radiation, such as television sets, microwave cookers, X-ray units, ultrasonic therapy equipment, mobile telephone sets, and other devices 
These devices should be certified in accordance with the Law on Food Products, Drugs, and Cosmetics. The controlling authority for these devices is the Radiological Safety Center of the USA Food and Drug Administration (FDA).

b) Radio frequency devices such as radio receivers, radio transmitting devices, radio recorders, and other devices

The certification of these devices is accomplished by the USA Federal Communications Commission.

\section{Great Britain}

In Great Britain, there is no direct control over internal marketing of imported consumer products, and such products are controlled in accordance with the general requirements for internal marketing control, specifically, in accordance with the requirements of the Goods Trade Act (1979), which also applies to consumer protection, as well as the Goods and Services Supply Act (1982), the Consumer Protection Act (1987), and the Regulations for Consumer Protection in Remote Marketing (2000). All these acts are focused on responsibility for the quality of the consumer products and for consumer safety.

\section{Germany}

In the Federal Republic of Germany, control in the area of external trade is accomplished by the Federal Service for Economy and Export Control and, in special cases, by the Ministry of Economy and Technology, the Ministry of Food, Agriculture, and Consumer Protection, the Ministry of Transport, Construction, and Housing, the Ministry of Finance, and the German Central Bank. Licenses for performing export and import operations in accordance with the Law on External Economic Activity are issued by the Ministry of Economy and Technology, the Ministry of Food, Agriculture, and Consumer Protection, the Ministry of Finance, and the German Central Bank. Licenses may be individual or general.

The Law on Customs Management supplements and specifies the customs legislation documents of the European Union and, specifically, specifies the organizational structure and functions of the system for controlling and registering product flows. This Law specifies for the Customs Service, which is subject to the Ministry of Finance, additionally to fiscal tasks, powers to control export and import operations and issuance of licenses, to perform the functions of the state internal market regulation, and to control the compliance of products with the specified sanitary and veterinarian requirements.

The consumer products imported from countries, which are not members of the European Union, to the Germany for internal consumption are subject to customs clearance within a specified period of time. 
In order to diminish load on the border customs stations, customs clearance procedures are performed at internal customs stations after the corresponding preliminary customs procedures had been performed at the border customs stations. After the customs procedure at the border customs station had been performed, the products can be transported from the border customs station to the internal customs station according to the customs mode provided for internal transport operations. When the customs clearing procedure for the products at the internal customs station has been performed, the products are free for marketing, provided that the following conditions are met:

1. The customs declaration and accompanying documents (invoices, transport documents) have been submitted.

2. The customs declaration has been approved by the customs station.

3. The documentation and products have been inspected, and the corresponding report on the inspection results has been prepared.

4. The amount of import duty and payment terms have been determined.

5. The corresponding payments have been effected.

Additionally to the customs law, depending on the product characteristics, it is necessary to consider laws and regulations concerning market relations, origin of the products, external economic activity, and health care.

In the European Union, the cost of imported products is determined in accordance with the General Agreement on Tariffs and Trade Code for Determining Customs Value. The amount of customs duty is determined with consideration for the contract according to which the products have been imported. If the customs value cannot be determined, one of the following five methods for determining the estimated cost of the imported products should be used:

1. The method based on the cost of the products specified in the contract

2. The method based on the cost of the products in accordance with the contract for supply of similar products

3. The method based on deduction of amounts

4. The method based on addition of amounts

5. The method based on determining the final estimated cost

According to Article 32 of the General Agreement on Tariffs and Trade, if the cost of products is underestimated, for example, in order to evade the payment of customs duty, the underestimated cost amount should be increased by the difference between the estimated cost amount determined by using the aforementioned method and the cost amount specified in the contract.

Activities in the area of customs and pricing policy are controlled by the Ministry of Economy and Technology, which is responsible for coordinating 
the policy with the corresponding authorities of the European Union. The internal control of imported products supplied from countries which are not members of the European Union is accomplished by the Ministry of Finance with the subordinate Customs Service.

\section{France}

The basic normative legal documents for controlling the marketing of consumer products in France are the International Agreement of the European Union with the additional French codes, such as the Customs Code, the Trade Code (in relation to competition law), the Consumption Code, the Code for Agreements Concluded by Governmental Authorities, the Health Protection Code, the Social Protection Code, the Labor Protection Code, the Construction Code, and the Intellectual Property Code.

The general requirements concerning the marketing of products within the European Union are contained in EU New Approach Directive, which was approved by the European Commission in 1985 and is based on the following conditions:

1. There are national normative legal documents concerning special safety requirements in countries which are members of the European Union.

2. Only such products which comply with special safety requirements are allowed to be freely marketed in the European Union.

3. The corresponding European institutions are responsible for developing technical specifications for products in accordance with the European normative legal documents.

4. The technical specifications for products are not mandatory if the product manufacturer use production equipment and processes which ensure the compliance of the products with the specified requirements.

5. The compliance of products with the Directive requirements should be confirmed by the corresponding authorized governmental authorities.

For implementing this Directive, in is necessary to intensify control and coordination of market activities and to provide the mandatory identification of the product manufacturer, storage of the information concerning the marketing of products, and availability of licenses required in the European Union.

Interaction and cooperation in connection with the internal marketing of products is accomplished via the European information system (RAPEX) designed for controlling marketing of all potentially hazardous products, excluding food products, pharmaceutical products, and medical-care products. This system provides the possibility to exchange information, concerning potentially hazardous products, between the European Commission and members of the European Union. The RAPEX system provides the possibility to collect information on actions of the national control authorities, product manufacturers, and product distributors. Every 
Friday, the list of potentially hazardous products is published according to the data submitted by the national control authorities. This list contains all the information on products, including the information on potential hazards in connection with the products and on actions performed by the corresponding national controlling authorities in response to such information.

Control over marketing of consumer products is accomplished by the General Directorate for Customhouses and Indirect Taxes (Direction Générale des Douaneset Droits Indirects) and the General Directorate for Competition, Consumption, and Reaction against Illegal Trade (Direction générale de la Concurrence, de la Consommation et de la Répression des Fraudes) with authirazed agencies in France. The comtrol begins at the stage of customs clearance of the ptoducts. The importer shoult submit the corresponting declaration to the customs agency of the General Directorate for Customhouses and Indirect Taxes. The customs agency, in accordance with the declaration, should verify the compliance of the products with the requirements of the national legislation and EU regulations. If the customs authority has permitted import of the product to France, the customs agency should issue a quality certificate for the products. If the verification results are controversial, the customs agency may require the product samples for testing the samples in the appropriate laboratory of the General Directorate for Competition, Consumption, and Reaction against Illegal Trade.

The authorized agencies of the General Directorate for Competition, Consumption, and Reaction against Illegal Trade control all processes in relation to the manufacture, import, and distribution of products.

The most intensive activities of the General Directorate are in connection with plant products subjected to risk of pesticide contamination, as well as with potentially hazardous products for children, sports, or entertainment.

The control of quality and safety of products, including imported products, marketed in France, is based on the testing and expert examination of the products in laboratories of the General Directorate by performing the following activities:

1. Analysis

2. Scientific and technical support

3. Additional studies

The General Directorate for Customhouses and Indirect Taxes and the General Directorate for Competition, Consumption, and Reaction against Illegal Trade jointly control marketing of imported products and ensure the testing of such products if the products do not comply with the specified quality requirements. Defective or hazardous products are removed from the market and disposed. Enterprises which allowed the marketing of such products are subject to administrative or criminal responsibility. 


\section{Brazil}

According to the information presented by the Brazil Ministry of Development, Industry, and External Trade, there is no special mode of control over the marketing of imported products in Brazil. The marketing of imported products, after all customs procedures had been performed, is accomplished in the same manner as the marketing of national products.

It should be noted that every importer in Brazil is subject to registration with the governmental agency relating to external trade, that is, with the External Trade Secretariat of the Ministry of Development, Industry, and External Trade. The importer data are entered into the SISCOMEX data base.

The operations required for customs clearance of imported products are the following:

1. Licensing the products (only products of special categories).

2. Registering the customs declaration for the products with the corresponding customs authority.

3. Performing customs inspection of the products as follows:

a) inspection of products of special categories only (green level inspection);

b) inspection of the accompanying documents for the products (yellow level inspection);

c) inspection of the accompanying documents and physical control of the products (red level inspection);

d) inspection of the accompanying documents and physical control of the products, and additionally, the detailed analysis of the products, for example, in order to determine the customs value of the products or the compliance of the products with the Brazil law requirements (gray level inspection).

4. Performing the customs clearance procedure, including payment of customs fees.

5. Transporting the products to the specified destination points.

In accordance with the Consumer Protection Law, the importer is responsible for the quality of the imported products. The marketing of any consumer products in Brazil is permitted only if the products comply with the requirements of the national standards and normative documents, relating to the composition, marking, and packing of the products, specified by the National Institute for Metrology, Standardization, and Product Quality Assurance which is in the area of responsibility of the Ministry of Development, Industry, and External Trade. The products should be marked with information, in Portuguese, on the composition, production date, and pull-date of the products. The National Institute also controls activities in connection with the certification of imported products and maintains the list of products and services which are subject to mandatory certification. 


\section{Canada}

The control of exported and imported products in Canada is based on the federal and provincial laws and regulations. Import of most products to Canada is possible without special permits, except some special products (about 70 product names), import of which is limited. The Import Control List and the Export Control List are compiled by the federal government in accordance with the Export and Import Permit Act. The importer should apply to the Ministry of Foreign Affairs and International Trade with a request for obtaining an import permit. Some products are imported on the basis of special documents made out by some federal authorities (the Ministry of Agriculture and Food Products, the Ministry of Fishing Industry and Ocean Resources, and other authorities). In this case, the control of exported and imported products is accomplished in accordance with the Meat Inspection Act, the Fishery Product Inspection Act, the Plant Product Inspection Act, the Plant Quarantine Regulations, and other regulatory documents.

The imported products subject to control include textile products, clothing, agricultural products, metals, arms, and ammunition. Other imported products are not subject to control and do not require special import permits.

For imported products which are not subject to control, an internal import certificate may be required. This certificate is a guarantee document which confirms that the Canada government permits import of the products by the declared importer.

Imported products must comply with the Canadian regulations for marking such products and with requirements for labels on imported products.

Imported products are marketed in Canada in accordance with the corresponding federal and provincial regulatory documents in the same manner as products of national origin,

The basic federal authority in Canada responsible for controlling safety of marketed consumer products is the Ministry of Health. The Ministry specifies the maximum allowed content of toxic substances, such as lead, cadmium, mercury, and other substances. in consumer products and in products potentially hazardous for the environment.

In order to improve the safety of imported products, the Ministry cooperates with the Canadian Frontier Service in detecting potentially hazardous imported consumer products.

\section{South Korea}

In the 1960s, the Republic of Korea adopted the export-oriented strategy of economic development, which requires the transparency of the national 
economy and integration of Korea into the international economic community.

The state sector of economic activities in Korea holds a leading position in the economy of Korea and is strictly controlled by the government.

Since 1970s, the following 7 industries have been emphasized by the special laws as top-priority industries: mechanic engineering, electronic engineering, textile industry, iron and steel industry, nonferrous-metals industry, petroleum chemistry, and shipbuilding industry. These industries have preferential access to resources and tax exemptions.

The state control of product quality is provided in the primary areas of product export.

The strict state control is provided for foreign investments. It should be noted that direct foreign investments in $1967 \ldots 1986$ were less than 2 percent of the total domestic investments. Korea attracts only such inward investments which comply with the adopted strategy of economic development. Therefore, not less than two thirds of foreign investments are concentrated in petroleum chemistry, mechanic engineering, and electronic engineering.

Korea actively uses import customs duties in order to protect its national producers and promote export of products. The customs duties are 5 ... 20 percent of the product cost for raw products and industrial products which are not produced in Korea, $25 \ldots 60$ percent for raw products and industrial products which are produced in Korea, and $80 \ldots 150$ percent for raw products and industrial products which are not essential for the Korea economy. In some cases, raw products which are essentially required for the areas of product export are released from customs duties. The state controls import activities also by limiting issuance of import licenses.

The Korean economy significantly depends on external trade. The part of external trade with China was 2.9 percent in 1991, when the system for analyzing statistical data characterizing the dependence of economy on external trade was implemented, and 10.8 percent in 2001. In this regard, China was ahead of Japan in 2003 and USA in 2004 and became the largest trade partner of Korea. Due to this, the dependence of the Korean export on trade with China increased significantly. The export volume in the trade of Korea with China was 1 billion US dollars in 1991 and increased to 86.7 billion US dollars in 2009. The part of export trade with China was 1.39 percent in 1991 and increased to 23.85 percent in 2009. Over the same period of time, the cost of products imported from China to Korea increased from 3.4 billion US dollars to 52.3 billion US dollars (from 4.32 percent to 16.79 percent).

The stably high rates of economic growth in China changed the structure of the Korean external trade, specifically, due to the increase of the volume 
of trade on the give-and-take basis, according to which Korea exports raw products and semi-finished products to China and imports final products from China. The part of export trade on the give-and-take basis was about 10 percent of the total export trade of Korea with China in 2004 and increased to 24 percent in 2009. At the present time, the part of import trade on the give-and-take basis is about 12 percent.

It should be noted that the free trade agreements concluded by Korea with some countries provide for relaxation in requirements for custom charges and tariffs for importers.

Before the 1980s, the trade policy of Korea was focused on increase of export and control of import, as the Korean economy was characterized by the trade balance deficit and lack of foreign exchange. At the end of 1980s, Korea revised its trade policy in order:

a) to actively participate in the formation of the new international trade system, specifically, within the limits of the Uruguay Round of the General Agreement on Tariffs and Trade (GATT), and in the international economy;

b) to provide the implementation of the national program for cancellation of restrictions on imports and other programs promoting the market stabilization;

c) to remove obstacles for investments and, as a result, to promote access to the Korean market.

In October 1989, the Korea government terminated one-sided restrictions on imports, which were provided in accordance with Article XII of the GATT, and agreed to gradually cancel the restriction to June 1997.

In March 1991, Korea presented the plan for the first stage of liberalization of imports for 1992, 1993, and 1994, according to which Korea provided a free trading mode for 43 product names. The level of liberalization of imports was 98.8 percent in 1994, after providing a free trading mode for additional 47 product names, 99.9 percent at the end of 1999, and 100 percent in 2001,

Since 1983, the customs duties in Korea had been reduced gradually from 23.7 percent in 1983 to 10.1 percent in 1992. Over the same period of time, the customs duties for industrial products had been reduced from 22.6 percent to 8.4 percent. In accordance with the system of customs privileges and import quotas, significantly lower customs duties were provided for products in which Korea was interested.

From January 1988, customs privileges were granted to 319 products, including beauty products, construction equipment, electronic devices. and cars. Import quotas were granted to 35 products, including cereal products, unrefined sugar, and refined sugar.

Since July 1988, import quotas tariffs for 691 products (391 raw products and 300 consumer products) has been reduced by 8.5 percent. 
Table 1

Implementation of preferential customs duties in Korea

\begin{tabular}{|c|c|c|c|c|c|c|c|c|}
\hline \multirow{2}{*}{$\begin{array}{c}\text { Product } \\
\text { code }\end{array}$} & Product & \multicolumn{7}{|c|}{ Customs duty (\%) } \\
\cline { 3 - 9 } & Live pigs & 20.9 & 19.7 & 18.6 & 18.0 & 18.0 & 18.0 & 18.0 \\
\hline 0303 & $\begin{array}{c}\text { Frozen fish } \\
\text { (salmon) }\end{array}$ & 10.0 & 10.0 & 10.0 & 10.0 & 10.0 & 10.0 & 10.0 \\
\hline 0401 & Milk and cream & 41.7 & 39.4 & 37.1 & 36.0 & 36.0 & 36.0 & 35.0 \\
\hline 0803.00 & Fresh bananas & 95.0 & 93.0 & 91.0 & 90.0 & 90.0 & 90.0 & 90.0 \\
\hline 1513.11 & Crude coconut oil & 28.5 & 27.9 & 27.3 & 27.1 & 27.0 & 27.0 & 27.0 \\
\hline 2009.60 & Grape juice & 47.5 & 46.5 & 45.5 & 45.0 & 45.0 & 45.0 & 44.0 \\
\hline 2901.10 & Butane & 5.0 & 3.0 & 1.0 & 0 & 0 & 0 & 0 \\
\hline 2930 & $\begin{array}{c}\text { Organosulfur } \\
\text { compounds }\end{array}$ & 13.3 & 10.6 & 7.9 & 6.5 & 6.5 & 6.0 & 5.5 \\
\hline 3006 & $\begin{array}{c}\text { Pharmaceutical } \\
\text { products }\end{array}$ & 9.4 & 3.1 & 0 & 0 & 0 & 0 & 0 \\
\hline 3303.00 & $\begin{array}{c}\text { Perfumery } \\
\text { products }\end{array}$ & 28.8 & 24.4 & 19.9 & 15.4 & 11.0 & 6.5 & 3.5 \\
\hline 4001.10 & Natural latex & 2.0 & 2.0 & 2.0 & 2.0 & 2.0 & 2.0 & 2.0 \\
\hline 5201.00 & Cotton & 6.0 & 4.4 & 2.8 & 2.5 & 2.0 & 2.0 & 2.0 \\
\hline 6103.11 & Suits of clothes & 35.0 & 35.0 & 35.0 & 35.0 & 35.0 & 35.0 & 35.0 \\
\hline 7206.10 & $\begin{array}{c}\text { Iron and steel in } \\
\text { ingots }\end{array}$ & 5.0 & 3.0 & 1.0 & 0 & 0 & 0 & 0 \\
\hline 8527.21 & Optical fibers & 16.0 & 16.0 & 16.0 & 16.0 & 16.0 & 16.0 & 16.0 \\
\hline 9001.10 & Radio receivers & 8.0 & 8.0 & 8.0 & 8.0 & 8.0 & 8.0 & 8.0 \\
\hline 8421.11 & Cream separators & 13.0 & 13.0 & 13.0 & 13.0 & 13.0 & 13.0 & 13.0 \\
\hline 9701.10 & $\begin{array}{c}\text { Pictures, } \\
\text { drawings }\end{array}$ & 0 & 0 & 0 & 0 & 0 & 0 & 0 \\
\hline
\end{tabular}

In December 1991, the National Assembly of Korea ratified the agreements of the Uruguay Round of the GATT.

\section{Japan}

In accordance with the legislation of Japan, all imported products are subject to control and cannot be used in Japan without certification in accordance with the specified normative documents, which are classified as mandatory standards and regulations and optional standard and regulations. The compliance of products with the specified normative documents is verified by the National Engineering Assessment Institute and the National the National Science and Technology Institute on request of the Ministry of Economy, Science, and Technology based on the application of the supplier, manufacturer, or importer of the products.

The state authority responsible for the standardization of products in Japan is the Industrial Standards Committee, which renders consultation services to the Ministry of Economy, Science, and Technology. The Committee is responsible for more than 600 industrial products and maintains more than 8500 standards. The tasks of the Committee are to 
establish and support regional industrial standards committees, to control processes of product certification, to participate in the development of international standards, and to promote the implementation of standardization systems. Since 1996, the Committee has been exchanging information with European standardization agencies, specifically, with the European Committee for Electrical Standardization (CENELEC).

Any enterprise in Japan has no right to manufacture, import, or sell appliances without proper marking in accordance with the existing standards. Application of labels to imported appliances is allowed only after permission to import the appliances is obtained, and if required, after factory inspection of the quality of the appliances.

The Law on Appliances and Material Safety, the Law on Product Safety, and the Civil Cote of Japan require that transport documents for imported products must contain detailed information on the products. According to the legislation of Japan, labeling of appliances and other consumer products is mandatory.

According to the Law on Appliances and Material Safety, the Ministry of Economy, Science, and Technology has the right to authorize its representatives to inspect offices, factories, workplaces, shops, warehouses, and product documentation. Hazardous products detected are not permitted to be marketed in Japan.

Before obtaining the permission to market appliances, the supplier must inspect the appliances for compliance with the specified requirements in accordance with the Regulations for Appliances and Materials approved by the Ministry of Economy, Science, and Technology. If the appliances comply with the requirements and are approved by the Ministry, the supplier, manufacturer, or importer of the appliances has to pay appropriate charges in connection with the inspection. The information on the appliances should be published in the official journal of the Ministry.

The Ministry of Economy, Science, and Technology permits marketing of appliances only if the appliances comply with the specified ISO and IEC standards.

\section{CONCLUSIONS}

For further improvement of the consumer protection system, it is necessary to tighten control of the quality and safety of products and ensure the compliance of products with the requirements of national and international standards, laws of Ukraine, and regulations of the European Union. The activities in connection with this are the following:

1. To carry on negotiations and conclude bilateral agreements with trade partners of Ukraine in order to prevent illegal import and marketing of products. 
2. To improve customs control in order to prevent import of products hazardous for human health and the environment.

3. To control the characteristics and origin of the products declared at the delivery of the products.

4. To implement information technologies and more intensively use electronic equipment for information processing.

5. To restructure the customs control system by:

- concluding bilateral agreements with countries which are members of the World Trade Organization (WTO);

- increasing the level of equipment support and providing certification of testing laboratories in accordance with the requirements of international standards;

- implementing regulations and standards in accordance with the Law of Ukraine on the State Marketing Control and Nonfood Product Control ${ }^{4}$.

\section{SUMMARY}

This paper deals with the international practice and approaches in connection with the organization and implementation of the state control over marketing of imported consumer products. It analyzes the main problems in the area of the state control of consumer products and consumer protection in Ukraine in order to promote the modernization of the Ukrainian economy and improve the quality and safety of consumer products.

\section{REFERENCES}

1. Про захист прав споживачів; Закон України, 12.05.199, № 1023-XII; zakon.rada.gov.ua/laws/show/1023-12

2. Про державний ринковий нагляд і контроль нехарчової продукції; Закон України, 02.12.2010, № 2735-V; zakon.rada.gov.ua/laws/show/2735-17

3. Про загальну безпечність нехарчової продукції; Закон України, 02.12.2010, № 2736-VI; http://zakon.rada.gov.ua/laws/show/2736-17

4. Про відповідальність за шкоду, завдану внаслідок дефектності продукції; Закон України, 19.05.2011, № 3390-V; zakon.rada.gov.ua/laws/ show/3390-17

5. Про основні принципи та вимоги до безпечності та якості харчових продуктів; Закон України, 22.07.2014, № 1602-VII; http://radakmu.org.ua/uploads/file/-/280915_01.pdf.

6. Про затвердження переліку органів державного ринкового нагляду та сфер їх відповідальності; Постанова Кабінету Міністрів України, 01.06.2011, № 573; zakon2.rada.gov.ua/laws/show/573-2011-п

\footnotetext{
${ }^{4}$ Про відповідальність за шкоду, завдану внаслідок дефектності продукції; Закон України, 19.05.2011, № 3390-V; zakon.rada.gov.ua/laws/show/3390-17 
7. Віткін Л.М., Вдосконалення державного ринкового нагляду за безпечністю нехарчової продукції відповідно до європейських підходів; Л. Віткін: Стандартизація, сертифікація, якість, 2012, № 5, с. 18-25.

8. Наумов О.Б., Свтушенко Є.О., Проблеми та шляхи підвищення ефективності споживання ресурсів у Херсонській області; Економічний простір: Збірник наукових праць. 22/2, ПДАБА, 2009, с. 108-115.

9. Притульська Н.В., Система захисту прав споживачів в Україні: проблеми реформування; Н. Притульська: Товари і ринки, 2015, № 2, c. $5-16$.

10. Гнатьєва Т.М., Вплив соціальної відповідальності бізнесу на конкурентоздатність підприємств аграрного сектора; Т.М. Гнатьєва, O.В. Ніколюк: Вісник Чернігівського державного технологічного університету, 2014, № 4(76), с. 151-158.

11. Gryshova I.Y., Stability of the competitive position of the agricultural sector in Ukraine at internal and external markets; І.Ю. Гришова, О.В. Митяй, В.В. Кужель: Актуальні проблеми економіки, 2016, № 3(177), с. 66-73.

12. Захожай В.Б., Управління якістю; В.Б. Захожай, Н.Г. Салухіна, О.М. Язвінська, А.Ю. Чорний, за науковою редакцією В.Б. Захожая: Навчальний. посібник для студентів вищих навчальних закладів, Видавничий дім «Персонал», 2011, 936 с.

13. Мандибура В. О., Особливості формування інституту довіри в системі забезпечення якості споживання та захисту прав споживачів; В. О. Мандибура, С. Г. Батажок: Вісник Інституту економіки та прогнозування, 2009, № 1, с. 69-73.

\section{Information about the author:} Khyzhniak V. O.,

Candidate of Economic Sciences, Director of the State Enterprise «Research Institute of Building Production named of V. S. Balitsky» 51, Lobanovskyi ave., Kyiv, 03110, Ukraine 


\section{STRATEGIC ASPECTS OF ECONOMIC SECURITY LEVEL FORMATION AS A PRECONDITION FOR BUILDING SAFETY}

\section{Stetsenko S. P.}

\section{INTRODUCTION}

Economy is a multi-level system of social relations, where a macro level is the main one. At this level we deal with the functioning of complex large independent economic systems, most of which are national economies. At the micro level we study the functioning of simple homogeneous systems and entities that make up macroeconomic structures. Such entities are economic entities and households. And last but not the least, is the mesolevel, which forms complex subsystems that are components of national economies, such as regions and industries.

Studies of certain aspects of the issue of economic security were considered in the works of leading Ukrainian scientists: L.I. Abalkina, A.I. Arkhipova, O.M. Bandurka, I.Ya. Bogdanova, Z.S. Varnalia, A.S. Galchinsky, V.M. Heyts, O.M. Golovchenko, V.E. Duhova, Ya.A. Zhalila, G.A. Pasternak-Taranushenko, V.L. Tambovtseva, L.S. Shevchenko, M.M. Yermoshenko et al.

In recent years modern economists have paid considerable attention to the notion of economic security for business entities. For construction companies, this concept is little known and poorly understood. Economic safety of construction enterprises is researched in the works of A.F. Goiko, L.V. Sorokina, Fedosova O.V., Molodid O.O., Vakhovich I.V., Migus I.P., Kushniruk A.O. et al.

The main purpose of the article is to study the formation of individual strategic aspects of economic security levels and the prerequisites for creating an economic security system for construction.

\section{Theoretical and practical prerequisites}

for the formation of strategic aspects of economic security as a basis for the development of economic systems

The current stage of the Ukrainian society development, characterized by the search for a paradigm of sustainable socially oriented recovery and growth, is accompanied by a qualitative transformation of the institutional environment, which has its manifestation in the redistribution of property rights and aggravation of contradictions between existing, reformed and 
imported institutions, decentralization trends in regions and industries. Such changes are complicated by the incompleteness of structural transformations, the lack of a holistic concept of long-term state development, the exacerbation of internal and external risk factors for the national security system in the context of intensifying globalization processes. This causes unstable transformational dynamics of key macroeconomic indicators.

Meanwhile it activates the opportunistic behavior of economic agents, which is an attempt to avoid the tax burden, blocking competition in the commodity and financial markets, a way to gain illegal access to budget resources and state property, redistribution of national income, export of capital abroad.

At present, Ukrainian society needs a new scientific paradigm which, in line with the challenges of post-industrial economy in the post-crisis development, will provide a qualitatively new interpretation of the principles of institutional design of the national security system and its attributive element - the system of economic security. The influence of formal and informal institutions on the content and principles of the functioning of the economic security system is characterized by contradiction, as market institutions can act as both a means of providing it and a factor of threats. The nature of the impact is determined by the content of forms and methods of institutional design, and the role of the state in realizing the positive potential of economic security institutions as a source of translational macroeconomic dynamics is of paramount importance, due to its heterogeneity as a result of the contradictions of institutional entities, and forced on mass and rapid import of market institutions. This determines the need to implement a state regulated option of market institutionalization of economic security relations based on the modernization of existing formal and legalization of informal institutions in the process of purposeful institutional design.

Ensuring economic security is crucial enough to formulate a strategy for socio-economic development of Ukraine. The problem of economic security of Ukraine is caused by liberalization of economy and foreign economic activity, globalization of the world economy, processes of regional and sectoral economic integration, formation of mechanisms of cooperation and interaction of Ukraine with other countries of the European Union, as well as factors of international cooperation with highly developed economies. Realities show that these days regions, enterprises, organizations, corporations, individual entrepreneurs become independent participants in foreign economic activity.

The main national interests in building the economic security system are achieved through the following important tasks:

- the ability of the economy to function in extended reproduction mode; 
- maintaining state control over strategic resources, preventing their extensive outflow that could harm the national interests of the state;

- elimination of dependence of the economy on the import of the most important types of production, which can be produced at the required level in the country;

- maintaining an acceptable standard of living, preventing poverty rates, property differentiation of the population and unemployment beyond the limits, possible considering socio-political stability in society;

- stability of the financial system, banking system and national currency;

- the proper level of development of the Ukrainian financial and securities markets;

- reduction and effective management of external and internal debt;

- providing financial conditions for activation of investment activity;

- preservation of a single economic space and developed interregional economic relations, ensuring the observance of national interests.

In today's conditions, it is of particular importance to ensure the economic security of Ukraine for its regions, industries and business entities. In doing so, national security must be viewed, on the one hand, as a condition of the state, enabling it to protect the vital interests of the individual, society and the state from internal and external threats, while preserving its integrity and status, on the other, as a preventive system for a timely crisis prevention.

The current state of the management system is characterized by the absence of a sectoral hierarchy, but this in no way limits the use of economic security mechanisms. In addition, the industry is a collection of independent and independent economic entities, which requires detailing the specifics and specifics of their spheres of activity in the economic space of the country and the region, as well as while identifying threats to economic security. It should also be borne in mind that the interests of economic operators generally need to address their own security in the short, medium and long term, although this is indirect but concerns the economic security of both the regions and the country as a whole.

Regardless of the level of concentration of property, the economic entity must be an element of the set of participants in economic relations, and in this regard, its economic interests are intertwined with regional and state ones and should be taken into account when identifying threats, taking into account industry specificities.

It should be pointed out that the level of concentration of property in modern Ukraine has led to the creation of a mesoeconomics of the country of «oligarchic» type with a significant prevalence of holding structures in it. The corporate nature of management limits the ability of regions to regulate the activities of such companies, holdings with corporate privileges. The loss 
of control over the regional economy is also associated with the free movement of financial resources, with their concentration in large centers of the economy. In this respect, the security of the regions is closely intertwined with the sectoral one, and the extent to which their economic and social interests coincide significantly influences the likelihood of obstacles and threats.

The tasks of regional and sectoral institutes and structures to ensure economic security include not only combating the offenses of fiscal legislation, detecting, preventing and ending violations of monetary and financial legislation, but also ensuring compliance with laws, regulating relations in the fields of business and other economic activity as well as property relationships.

In modern conditions, the regions of Ukraine have developed as integral economic systems with their own peculiarities and economic policy, as well as independence in the choice of economic development strategy. The formation of a regional economic security system should be based on the substantiation of the system of economic interests of the region, interaction with industry and corporate structures, and virtually results from the system of national economic interests.

One of the aspects of the study of economic security issues and peculiarities of its provision at the regional level involves preservation of the administrative structure of the state. It is not always taken into account that there exists heterogeneity of problems solved at different levels of the economic system of the country, and a significant raw material orientation of the Ukrainian economy in terms of exhaustion and non-renewability of natural resources. In particular, T.Yu. Feofilova notes that the economic security of the country is a state of the economy, which in the conditions of limited natural resource potential and even under the influence of negative factors allows the state authorities and local selfgovernment bodies to perform their functions and to meet the needs of society, without undermining the state foundations and without threatening its sovereignty ${ }^{1}$.

The economic interests of the region are, first and foremost, the effective use of production potential and natural resources while ensuring favorable living conditions and social conditions of the population. Sectoral interests have similar priorities, but they are based on ensuring competitiveness through innovative development. Based on the interests of the region and the industry, an appropriate regional-sectoral strategy should be formed. In order to ensure economic security, it is necessary to involve an institutional mechanism for activating economic growth and competitiveness of the

\footnotetext{
${ }^{1}$ Feofilova T.Yu. (2009), “Osnovni katehorii teorii ekonomichnoi bezpeky”, Ekonomika ta upravlinnia, vol. 8 (46), pp. 22-25.
} 
economy as factors that make potential threats impossible. Competition is a key institutional framework for building a new paradigm of social development and building up a new social order.

The economy of an entity is dependent on political and social decisions made. Studying these circumstances makes it possible to understand the composition of institutional changes, which include a set of legal and economic management methods and help to identify threats in the economic sphere. An effective institutional system, pursuing public interests, organizes and harmonizes them in the pursuit of higher-level national interests, including national security ${ }^{2}$. This achieves the efficiency and unity of social development of the country in terms of modernization of its economy.

In the transition to an innovative and post-industrial economy, the basis of national security is a new quality of economic growth, in which scarce and non-reproducible natural resources are replaced by the effective use of scientific development. In the scientific sources there are 5 basic levels of the structure of the economy and its economic security: mega, macro, micro, mini and meso. Economic security is seen as a multilevel and multifactorial system for ensuring threats against all interacting levels of sectoral, intersectoral (corporate), territorial complexes, enterprises, as well as their subdivisions and employees.

Therefore, when considering economic security, several levels should be distinguished, namely:

1) economic security of the state, i.e. macroeconomic level;

2) economic security of the region, i.e. mesoeconomic level;

3) economic security of market agents (enterprises, organizations, institutions), ie microeconomic level;

4) economic security of households, ie nanoeconomic (basic) level.

The analysis of publications in the scientific literature has made it possible to identify three features that allow to classify approaches to the definition of the economic security level: sectoral affiliation (sectoral security); level of concentration of property (security of corporate structures); administrative and territorial structure (regional security).

The special role of meso levels is that they act as buffers in activating stability threats for the main levels of the economic system and serve as reserves in the event of an excess or shortage of factors, resources and conditions for sustainable development ${ }^{3}$.

Economic security, which determines the sustainable development of all levels of the economy, according to institutional theory, is associated with

\footnotetext{
${ }^{2}$ Tatarkyn A. T. (2006), "Ekonomichna bezpeka rehioniv - u iednosti teorii, metodolohii j praktyky", Ekonomika j keruvannia, vol. 4, pp. 28, 29.

${ }^{3}$ Holovchenko O.M. (2008), "Ekonomichna bezpeka rehionu v harantuvannia stabil'nosti natsional'noi ekonomiky”, [Ekonomichna bezpeka], Naukova dumka, Odesa, Ukrain.
} 
the establishment and functioning of organizational structures, laws and rules of conduct that ensure effective participation in globalization and informatization of the economy, innovation and business activity. Particularly important is the development of safeguards to prevent and minimize potential threats. The basis of such a mechanism can be the following criteria: the degree of activity in the formation of protection, the accuracy and completeness of the information field, the nature of the dangers, the system of monitoring the obstacles, the result of protection (avoidance of threats, achieving sustainable development).

The security strategy is the basis of a long-term strategy for the socioeconomic development of the country, not the other way around. In our view, a long-term strategy cannot be formulated without defining the national interests of the country. They express the substance of the essence of the country, sovereignty and its main characteristics in the world geopolitical space.

Regarding the organizational aspect of the security strategy, it is worth noting that there is a weak coordination in the economic and social spheres of our decisions. The market, of course, solves this problem, but only partially. It is necessary to ensure the unity of the management system in solving strategic goals, to balance the parameters of sustainable development with the existing and potential threats. A governing body is required to determine, on a scientific basis, the available resources, assess the potential of the national economic complex and the capabilities of science, and establish a system of natural and value balances. On this basis, it is possible to build a comprehensive strategy for the long-term development of the country, regions, industries, enterprises and households.

\section{Features of construction and its role in the construction of economic security systems}

Construction is a separate independent branch of the country's economy, which is intended for the introduction of new ones, as well as the expansion, reconstruction and technical re-equipment of existing objects of industrial and non-production purposes.

As a branch of material production, construction has a number of features that distinguish it from other industries. The peculiarities of the industry are explained by the nature of its final products, peculiar working conditions, peculiar properties of the technologies used, techniques, and methods of organization of the construction process and features of the construction production technology. As the technology of the construction process is quite complex, a mistake of even one worker can lead to accidents at the construction sites, as a result of which the company suffers considerable financial and material losses. 
Territorial remoteness of the construction sites from the locations of the contracting organizations complicates the management of the construction process, which has an impact on the increase of transport and material loss risks.

Time factor has a major impact on the technical and economic performance of the construction, as the construction of the construction site takes months or even years. Long duration of the construction process leads to the diversion of capital from circulation. Complexity of forecasting and planning the financial needs of a construction company, which may change during the construction process, such as changes in prices for construction materials, can cause an unforeseen suspension of the construction process and, as a consequence, lead to the loss of the image of the business entity and significant financial losses.

Construction is also characterized by certain peculiarities in staffing. Most construction workers, as a rule, are hired to perform a certain stage of work, which affects the lack of cohesion of the team, requires a greater attention to the coordination and management of personnel.

The wide variety of legal instruments in the field of construction law and the specifics of contracts for construction work lead to uncertainty in the understanding and interpretation of terms, and, as a consequence, to conflicts between participants in the construction process.

The activity of construction enterprises is regulated and controlled by the authorities. In order to begin the construction process, you must obtain a planning and construction approval from a number of services. Thus, the activity of a construction enterprise depends to a large extent on relations with the structures of state and local government. The authorities also establish or recommend pricing in the construction industry.

The general features of the entire industry, regardless of the objects being built and their purpose, include the following features:

1) variability, temporary nature, variety of construction production and nature of final products;

2) technological interconnection of all operations that are part of the construction process;

3 ) instable scope of construction works considering their complexity and types during the month;

4) participation of various organizations in the production of final construction products;

5) the role of climate and local conditions in construction works;

6) possibility of using construction products only at the place of production, i.e. its real estate; 
7) the services are provided not at the location of the construction enterprise, but at the site specified by the customer or at the location of the object;

8) long business cycle and low capital turnover;

9) high cost of construction objects, long duration of their operation;

10) the need to attract large amounts of resources, which explains the widespread practice of advance payments and one hundred percent subscription;

11) a high degree of individualization of the consumer (in most cases, the consumer of construction services is known until the time of construction of the construction object), which leads to the preliminary establishment of the contract price for the object or a specific mechanism for its determination;

12) availability of a large number of various information documents and the need to comply with the state requirements, norms and regulations;

13) high degree of opacity of procedures during licensing, obtaining permits.

Economic security of construction implies a state of efficient use of resources to prevent threats and ensure stable functioning.

The above features make it possible to determine the content of the main external and internal threats to the economic security of construction and determine the specifics of their management. As far as the external environment is concerned we can distinguish the following:

- crisis of the national economy;

- political instability;

- development of the shadow sector in the construction sector;

- imperfection of current legislation;

- high inflation;

- change in the exchange rate;

- high level of credit rates;

- reduction of quantity and quality of labor resources;

- low purchasing power of the population;

- weak technical regulation;

- imperfect competition;

- lack of investments and quality domestic building materials;

- energy dependence on other countries;

- force majeure (natural disasters, military conflicts, etc.);

- improper performance of contracts;

- irregular supply;

- high level of prices;

- delay in payment for work performed;

- breach of contractual relations.

Internal threats include the following: 
- ambiguity of goals;

- risky financing policy;

- inefficient management of assets and capital;

- low qualification of management personnel;

- seasonal fluctuations in construction;

- depreciation of fixed assets of most enterprises in the construction industry;

- simple equipment;

- increasing the level of turnover;

- work in difficult hazardous conditions, etc.;

- lack or superficial attitude to the marketing strategy;

- reducing the quality of human resources and efficiency of its use;

- significant working capital turnover period;

- wrong sales policy;

- low competitiveness of products.

Lack of stability of economic development of enterprises, a significant level of dependence on different types of threats and dangers, cases of unfair competition, fictitious entrepreneurship, raider attacks, necessitate the solution of issues for the further development of the construction industry of the country, creation of a reliable and effective system of financial security of construction enterprises in Ukraine.

Creating an economic security system and managing it effectively are necessary in order to counter and combat all kinds of threats and dangers.

Thus, in the development of the construction economic security system one should to take into account the specifics of construction activity and the above mentioned threats to the normal functioning and development.

The purpose of building a system of economic security for construction is to protect against external and internal threats to ensure stable functioning and financial and economic growth.

According to the purpose, the main tasks of the financial and economic security system should be the following:

1) timely identification of possible threats to economic security and taking measures to prevent them;

2) eliminating real internal and external threats to economic security;

3) ensuring the economic efficiency of the construction activity, its financial stability and independence;

4) ensuring the preservation of property and information security of construction enterprises at all stages of the construction process;

5 ) ensuring personnel security, which includes not only the selection of highly qualified employees, but also the formation of a training system for the industry, their certification, the organization of safe working conditions and personal safety; 
6) protection of commercial secrets by restricting access to trade secret information;

7) protection of interests of construction enterprises in cooperation with partners and local authorities and creation of a system of protection against raider attacks.

The main threats to economic security include:

- insufficient use of opportunities for Ukrainian companies to enter international capital and technology markets, since the quality of products is lower than international standards;

- mismatch of the motives of TNCs investment activity to the needs of structural restructuring of Ukraine. Of course, TNC owners are the main motive behind the multiplication of their profits and are almost in no way interested in developing a strong Ukrainian economy. This is explained by the reluctance to obtain in the future an additional competitor in the market for the sale of products and the purchase of production resources;

- monopolization of strategic industries. Artificially created barriers to increasing sectoral competition in all types of economic activities;

- lack of a comprehensive economic security strategy that needs to be developed to develop a sustainable development trajectory for Ukraine over the long term;

- limited access to financial, technical, technological and information resources;

- lack of effective mechanisms for transformation of temporarily free funds of individuals and legal entities into investments;

- regional and sectoral disparities in the investment of capital in its various forms. In particular, due to the uneven economic development and investment attractiveness, regional and sectoral disparities may arise in the investment flow;

- the deterioration of the investment climate caused by the occupation of the Autonomous Republic of Crimea, military actions in the East of the country, the consequences of the economic depression and uncertain prospects for economic growth, as well as issues of increasing the level of corruption, slowing down reforms and reducing the capacity and predictability of the state policy. This forced private companies to refuse or delay the implementation of investment projects for future periods ${ }^{4}$;

- lack of state support for the financial stabilization of the construction industry, which is perhaps the most important in the context of the ongoing study of the threat to national economic security. The catastrophic loss of the industry has already led to the negative total value of construction capital. In

${ }^{4}$ Ekonomichna ta may̆nova bezpeka pidpryiemstva i pidpryiemnytstva. Antyrey̆derstvo. B.M. Andrushkiv, Yu.Ia. Vovk, P.D. Dudkin ets. - Ternopil: Terno-hraf, 2008. 424 p. 
the future, this threatens to exit a large number of contracting companies and further reduce construction products, works and services. Therefore, the drastic consequence of this threat will be a further decrease of production capacities, the level of providing the population with quality trade facilities, transport infrastructure, and socio-cultural sphere.

In view of these threats, the task of creating a system of monitoring, analyzing and assessing economic security at the levels of the national economy, construction industry and regions, which underpins the model of system dynamics of development, becomes especially relevant. For this purpose economic security indicators and their limit values are used. Limit values are end values, the excess of which impedes the normal development of various components of the economic system, leads to the formation of negative, destructive tendencies in the field of economic security. Examples of internal threat indicators include the depreciation of fixed assets, the unemployment rate, the differentiation of household incomes, and the inflation rate. Their approximation to the maximum permissible (limit) value indicates an increase in threats to the economic stability of the society, and exceeding the limit values - a transition of society into a zone of instability and social conflicts, when economic security may be undermined. Indicators of external threats include the maximum permissible level of public debt, maintaining or losing positions in the world market, the dependence of the economy and its major sectors on imports of foreign products and raw materials. Obtaining limit values of economic security indicators is connected with the fundamental determination of national priorities of the country.

Indicators of particular importance are the following: gross national product - the market value of final goods and services produced in the country's economy over a specified period of time (year); rates of structural deformation of production and society. We should also highlight the following indicators of economic security: the coverage of imports by exports, export dependence, import dependence, the volume of outstanding on a specific date of loans made by the state in domestic and foreign loan markets, the budget deficit is excess of the budget revenues over the amount of the budget expenditure, the level of economy monetization, which is defined as a percentage as a ratio of money supply to annual GDP.

The most important macroeconomic and social indicators at the regional level are: 1) GRP dynamics, indicators of volumes, rates and structure of industrial production, investments, share of exports in production; 2) the state of the natural resource, production and scientific and technical potential of the region; 3) the ability of the economic mechanism to adapt to changes in internal and external factors (inflation, budget deficits, external economic conditions, debt, savings); 4) quality of life of the population (GRP per 
capita), unemployment rate and socio-demographic differentiation of incomes, average life expectancy.

Such macroeconomic indicators characterize the conditions of existence of the economic system of the country, industry, and region.

\section{CONCLUSIONS}

Thus, in order to design a risk minimization system as an element of economic security, it is necessary to select the most significant economic security indicators, determine and justify the limits of the selected indicators. It is necessary to establish a system of indicators and predicators for construction and to monitor them at the state, local government or selfregulatory level.

The formation of a model of system dynamics of the construction industry may increase the number of economic security indicators. It is also acceptable to form a single, generalized optimization parameter as a function of value, in which all indicators of economic security of construction will be reflected.

\section{SUMMARY}

The article reviews theoretical approaches to the formation of the economic security system at the macro micro and noneconomic levels of the economy. The author analyzes theoretical and practical preconditions for the formation of strategic aspects of economic security as a basis for the development of the economic system. At the same time, national security is viewed on the one hand as a condition of the state, enabling it to protect the vital interests of the individual, society and the state from internal and external threats, while maintaining its integrity and status, on the other, as a preventive system for early warning of the crisis. It is determined that the security strategy is the basis of the long-term strategy of socio-economic development of the country, not the other way around.

It is revealed that the level of concentration of property in modern Ukraine has led to the creation of mesoeconomics of the country of «oligarchic» type with a significant prevalence of holding structures in it. The corporate nature of management limits the ability of regions to regulate the activities of such companies, holdings with corporate privileges. Loss of control over the regional economy is also associated with free movement of financial resources, with their concentration in large centers of influence.

The author defines mesolevels as buffers in activating stability threats for the basic levels of the economic system serving as reserves in case of excess or lack of factors, resources and conditions for sustainable development.

The article gives the analysis of construction features including the nature of its final products, peculiar working conditions, the application of 
different technologies, techniques, and methods of organization of the construction process in the construction of each individual object, the territorial distance of the construction objects from the locations of contracting organizations, the considerable duration of the process, the complexity of forecasting and planning the financial needs of a construction company, which may change throughout the construction process, and its role in building a system of economic security.

It is argued that formation of the construction economic security system must take into account the specifics of the construction activity and the above threats to normal functioning and development, and the purpose of construction economic security system is to protect against external and internal threats to ensure stable functioning and economic growth.

This requires the establishment of a system for monitoring, analysis and evaluation of economic security at the levels of the national economy, construction industry and regions, as well as a system of indicators of economic security of construction and calculation of their limit values.

\section{REFERENCES}

1. Abalkyn L.Y. (1994), "Ekonomycheskaia bezopasnost' Rossyy: uhrozy y ykh otrazhenye",Voprosy ekonomyky, vol. 12, pp. 12.

2. Holovchenko O.M. (2008), "Ekonomichna bezpeka rehionu v harantuvannia stabil'nosti natsional'noi ekonomiky", [Ekonomichna bezpeka], Naukova dumka, Odesa, Ukraine.

3. Holubtsiv A. N. (2005), "Ekonomichna bezpeka rehioniv PFO", Pytannia statystyky, vol. 4, pp. 52-53.

4. Zhalilo Ya.A. (2003), "Ekonomichna stratehiia derzhavy: teoriia, metodolohiia, praktyka", [Ekonomichna stratehiia], Naukova dumka, Kyiv, Ukraine.

5. Shevchenko, L. S. Hrytsenko, O. A. and Makukha S. M. (2009), "Ekonomichna bezpeka derzhavy: sutnist' ta napriamy formuvannia", [Ekonomichna bezpeka], Naukova dumka, Kyiv, Ukraine.

6. Inshakova O.I. (2004), "Stalyj rozvytok krain SND: teoretychna kharakterystyka j systema indykatoriv", Visnyk S.-Peterb. un-ta., vol. 1.

7. Pasternak-Taranuschenko H. A. (1994), "Ekonomichna bezpeka derzhavy" [Ekonomichna bezpeka], Naukova dumka, Kyiv, Ukraine.

8. Tatarkyn, A.Y.. Kuklyn, A.A and Myzyn, A.L. (2009), "Monytorynh ekonomycheskoj bezopasnosty rehyonov kak uslovye stabyl'noho razvytyia" [Ekonomichna bezpeka], Naukova dumka, Ekaterynburh, Russia.

9. Olejnykov E. A. (2005), "Ekonomichna j natsional'na bezpeka", [Ekonomichna bezpeka], Naukova dumka, Kyiv, Ukraine.

10. Stepanenko A. (2002), "Otsinka ekonomichnoi bezpeky Ukrainy ta ii rehioniv", Rehional'na ekonomika, vol. 2, pp. 39-54. 
11. Tatarkyn A. T. (2006), "Ekonomichna bezpeka rehioniv - u iednosti teorii, metodolohii j praktyky", Ekonomika j keruvannia, vol. 4, pp. 28, 29.

12. Feofilova T.Yu. (2009), "Osnovni katehorii teorii ekonomichnoi bezpeky", Ekonomika ta upravlinnia, vol. 8 (46), pp. 22-25.

13. Ryzhakova G. Implementation of principles of biospheric compatibility in the practice of ecological construction in Ukraine [Tекст] / D. Chernyshev, I. Ivakhnenko, G. Ryzhakova, K. Predun // International Journal of Engineering \& Technology - UAE: Science Publishing Corporation, 2018 - Vol 10, No 3.2: Special Issue 2 - pp. 584-586.

14. Tetyana Marchuk, Dmytro Ryzhakov, Galyna Ryzhakova and Sergiy Stetsenko (2017). Identification of the basic elements of the innovationanalytical platform for energy efficiency in project financing. Investment Management and Financial Innovations Vol. 14(4), pp. 12-20.

15. Avdyiskyi, V.I. and Bauer, V.P. (2010) Ekonomichna bezpeka v systemi transformatsii svitovoi finansovoi arkhitektury, Efektyvne antykryzove upravlinnia. № 1. PP. 42-48.

16. Sorokina, L.V. and Goiko, A.F. (2016) Doslidzhennia zahroz investytsiinoi bezpeky budivelnykh pidpryiemstv, Budivelne vyrobnytstvo. V. 61. PP. 9-20.

17. Bielienkova O. Yu. Tendentsii rozvytku budivelnoi haluzi yak chynnyky formuvannia stratehichnoi konkurentospromozhnosti budivelnykh pidpryiemstv // Budivelne vyrobnytstvo. 2014. Vol. 57. P. 24-30.

18. Fedosova, O.V. Molodid, O. O. and Terenchuk, S. A. (2011) Vyznachennia rivnia ekonomichnoi bezpeky budivelnoho pidpryiemstva na osnovi ekonometrychnykh modelei, Upravlinnia rozvytkom skladnykh system. V. 5. - PP. 117-119.

19. Kushniruk, A. O. (2012) Pidkhody do otsinky ekonomichnoi bezpeky budivelnoho pidpryiemstva / Budivelne vyrobnytstvo. № 54. Pp. 77-81.

20. Mihus, I. P. and Laptiev, S. M. (2011) Rol sluzhby ekonomichnoi bezpeky aktsionernoho tovarystva u zabezpechenni yoho ekonomichnoi bezpeky. Ekonomika ta derzhava. N 12. PP. 15-17.

21. Vakhovych, I. V. (2015) Pidvyshchennia efektyvnosti upravlinnia biznes-protsesamy budivelnykh pidpryiemstv. № 59. PP. 3-6.

22. Zeltser, R.Ya., Bielienkova, O.Yu. and Dubinin, D.V. (2018) Innovatsiini modeli i metody orhanizatsii, upravlinnia i ekonomichnoi otsinky tekhnolohichnykh protsesiv budivelnoho vyrobnytstva Kyiv: «MP Lesia». 209 p.

23. Zeltser, R.Ya., Bielienkova, O.Yu., Novak, Ye., Dubinin D.V. (2019) Digital Transformation of Resource Logistics and Organizational and Structural Support of Construction. Nauka i innovatsii. V 15(5), pp. 38-51. 
24. Tytok, V. V. (2013) Formuvannia modeli zhytlovoho budivnytstva v misti. Shliakhy pidvyshchennia efektyvnosti budivnytstva $v$ umovakh formuvannia rynkovykh vidnosyn. V. 30. PP. 90-99.

25. Tymoshenko, O. V. (2019) Vyklyky ta zahrozy chetvertoi promyslovoi revoliutsii: naslidky dlia Ukrainy. Biznes Inform. Vol. 2. Pp. 21-29.

26. Ekonometrychnyi instrumentarii upravlinnia finansovoiu bezpekoiu budivelnoho pidpryiemstva : [monohr.] / za nauk. red. d.e.n., prof. L. V. Sorokinoi. - K. : Kyivskyi natsionalnyi universytet budivnytstva i arkhitektury; Kryvyi Rih : Vyd. FOP Cherniavskyi D. O., 2017. - C. 4-26.

27. Izmailova K.V., Bielienkova O.Iu., Moholivets A.A. (2019) Sutnist ekonomichnykh tsykliv ta yikh vplyv na ekonomichnu stiikist budivnytstva. Naukovi pratsi NDFI. 2019. № 2. PP. 139-150.

28. Tytok, V. V. (2012) Suchasnyi stan protsedury otrymannia zamovnykom budivnytstva dozvilnykh dokumentiv. Shliakhy pidvyshchennia efektyvnosti budivnytstva $v$ umovakh formuvannia rynkovykh vidnosyn. Vol. 28. P. 142-150.

\section{Information about the author:}

Stetsenko S. P.,

DSc in Economics, Associate Professor, Head of the Department of Construction Economics, Kyiv National University of Construction and Architecture (KNUCA) 31, Povitroflotsky ave., Kyiv, 03037, Ukraine 


\section{LONG-TERM FACTORS OF CONSTRUCTION BUSINESS DEVELOPMENT}

\section{Bielienkova O. Yu.}

\section{INTRODUCTION}

Strategic management of construction business addresses vital areas like the strategy of operation, development and behavior of the industry under the influence of environmental changes, of promotion of construction work and development of human resources. At that, determination of the priorities in development substantially depends on the specific market situation in which the industry is functioning and on the state of the environment.

Therefore, it is extremely important to identify the conceptual foundations of development of construction business in Ukraine, the key fundamental trends that will affect its functioning over a long period, that is, those foundations that will have the greatest effect on the industry's ability to be competitive and control the strategic development on the basis of the forecasts for the future state of the environment. Without account of such trends, control is focused on the operational level only, at the best, on the tactical level as well. At absence of a strategy, this often fails to produce the desired result and leads to decrease of the rate of development of industry over the long run.

The main purpose of the study is to identify the most consequential trends in environmental changes (of economic, scientific and technical, socio-political environment, etc.) that in the coming years are to have an impact on the construction business functioning and should be taken into account when elaborating the strategy for further development.

For the construction activity, the main tendencies of development of the industry in strategic perspective are the further integration into the European Economic Area, after the entry into force in 2017 of the Association Agreement with the $\mathrm{EU}^{1}$, the implementation of the energy saving programs in all sectors of the economy and in the public sector, as a key element for the energy security of the State, ecological orientation of construction

${ }^{1}$ Decree of the Cabinet of Ministers of Ukraine of October 25, 2017 No. 1106 "On the Implementation of the Association Agreement between Ukraine, on the one part, and the European Union, the European Atomic Energy Community and their Member States, on the other part"« https://www.kmu.gov.ua/ua/npas/pro-vikonannya-ugodi-pro-asociaciyu-mizhukrayinoyu-z-odniyeyi-storoni-ta-yevropejskim-soyuzom-yevropejskim-spivtovaristvom-zatomnoyi-energiyi-i-yihnimi-derzhavami-chlenami-z-inshoyi-storoni 
projects, deregulation and liberalization of economy, the effect of the financial and economic crisis, digital transformation of the economy, etc.

\section{Pro-European vector of foreign economic and political development}

Ukraine's accession to the European Economic Area, implementation of joint international projects, harmonization of the systems of normalization and quality assessment of construction products, bringing the Ukrainian national standardization system in compliance with the requirements and rules according to which the national standardization systems of the European Union Member States operate.

The basis for the strategy of development of Ukraine for the coming years is the course for integration into the European Union and a step by step harmonization of Ukrainian legislation, norms and standards with the relevant EU documents..

So, in 2004 the Law of Ukraine "On State Program for Adaptation of the Legislation of Ukraine to the Legislation of the European Union" has been adopted $^{2}$, in 2010 - the Law of Ukraine "On Principles of Domestic and Foreign Policy"3, in 2014 - Resolution of the Verkhovna Rada of Ukraine "On confirmation of Ukraine's course towards integration into the European Union and priority measures in this direction" ${ }^{4}$, those have made it possible to take concrete steps towards European integration.

Besides that, among the legislative and regulatory acts in the field of European integration in the last decade one shall point out the Decree of the President of Ukraine "The Issues of European and Euro-Atlantic Integration", the Decrees of the Cabinet of Ministers of Ukraine "The Issues of preparation and holding of meetings of individual bilateral bodies of association between Ukraine and the EU", "The Issues of Publication of Decisions and Recommendations of the EU-Ukraine Association Council

${ }^{2}$ The Law of Ukraine "On the State Program for Adaptation of the Legislation of Ukraine to the Legislation of the European Union" No. 1629-IV of March 18, 2004 https://zakon2.rada.gov.ua/laws/show/1629-15

${ }^{3}$ The Law of Ukraine "On the Principles of Domestic and Foreign Policy" No. 2411-VI of July 1, 2010 https://zakon.rada.gov.ua/laws/show/2411-17

4 "On confirmation of Ukraine's course towards integration into the European Union and priority measures in this direction" No. 874-VII of March 13, 2014 https://zakon5.rada.gov.ua/laws/show/874-18

${ }^{5}$ The Decree of the President of Ukraine of April 20, 2019 No. 155/2019 "The Issues of European and Euro-Atlantic Integration" https://www.president.gov.ua/documents/155201926586

${ }^{6}$ The Decree of the Cabinet of Ministers of Ukraine of December 10, 2014 No. 700 "The Issues of Preparation and Holding of Meetings of Individual Bilateral Bodies of Association between Ukraine and the EU" https://zakon1.rada.gov.ua/laws/show/700-2014-\%D0\%BF 
and the EU-Ukraine Association Committee"7, "The Issues of planning, monitoring and evaluating the effectiveness of implementation of the Association Agreement between Ukraine, on the one part, and the European Union, the European Atomic Energy Community and their Member States, on the other part» ${ }^{8}$, "On the Government Office for Coordination of European and Euro-Atlantic Integration", "On introduction of a State mechanism for coordinating the interaction of public authorities in order to protect the financial interests of Ukraine and the European Union" ${ }^{10}$, the Decree of the Cabinet of Ministers of Ukraine of July 18, 2018 No. 577 "On the Coordination Council for Implementation of the Communication Strategy in the Area of European Integration for 2018-2021"11, as well as the Directive of the Cabinet of Ministers of Ukraine "On approval of the Communication Strategy in the field of European integration for 20182021 "12 "On approval of the action plan for 2018 on implementation of the Communication Strategy in the field of European integration for 20182021 "13 " On approval of the 2019 action plan for the implementation of the

${ }^{7}$ The Decree of the Cabinet of Ministers of Ukraine of March 04, 2015 No. 84 "The Issues of Publication of Decisions and Recommendations of the EU-Ukraine Association Council and the EU-Ukraine Association Committee" https://zakon0.rada.gov.ua/laws/show/84-2015$\% \mathrm{D} 0 \% \mathrm{BF}$

${ }^{8}$ The Decree of the Cabinet of Ministers of Ukraine of May 31, 2017 No. 447 "The Issues of Planning, Monitoring and Evaluation of the Effectiveness of Implementation of the Association Agreement between Ukraine, on the one part, and the European Union, the European Atomic Energy Community and their Member States, on the other part" https://zakon2.rada.gov.ua/laws/show/447-2017-\%D0\%BF

${ }^{9}$ The Decree of the Cabinet of Ministers of Ukraine of October 04, 2017 No. 759 "On the Government Office for Coordination of European and Euro-Atlantic Integration" https://zakon5.rada.gov.ua/laws/show/759-2017-\%D0\%BF

${ }^{10}$ The Decree of the Cabinet of Ministers of Ukraine of October 25, 2017 No. 1110 "On the introduction of a State mechanism for coordinating the interaction of public authorities in order to protect the financial interests of Ukraine and the European Union" https://www.kmu.gov.ua/ua/npas/pro-zaprovadzhennya-nacionalnogo-mehanizmu-koordinaciyivzayemodiyi-organiv-derzhavnoyi-vladi-z-metoyu-zahistu-finansovih-interesiv-ukrayini-tayevropejskogo-soyuzu

${ }^{11}$ The Decree of the Cabinet of Ministers of Ukraine of July 18, 2018 No. 577 "On the Coordination Council for Implementation of the Communication Strategy in the Area of European Integration for 2018-2021» https://www.kmu.gov.ua/ua/npas/pro-koordinacijnu-raduz-realizaciyi-strategiyi-komunikaciyi-u-sferi-yevropejskoyi-integraciyi-na-20182021-roki

${ }^{12}$ Directive of the Cabinet of Ministers of Ukraine of October 25, 2017 No. 779-r "On approval of the Communication Strategy in the field of European integration for 2018-2021» https://zakon2.rada.gov.ua/laws/show/779-2017-\%D1\%80

${ }^{13}$ Directive of the Cabinet of Ministers of Ukraine of April 25, 2018 No. 272-r "On approval of the action plan for 2018 on implementation of the Communication Strategy in the field of European integration for 2018-2021" https://zakon2.rada.gov.ua/laws/show/7792017-\%D1\%80 
Communication Strategy in the area of European Integration for 2018$2021^{\prime \prime 14}$.

In Ukraine, a number of significant steps have already been taken to adapt the domestic construction industry to European standards. So, in 2010 the Law of Ukraine "On Building Regulations" 15 has come into force, and from the 1 of July, 2014 - a mechanism for concurrent effect of the national building regulations and the building regulations harmonized with the EU regulatory documents. The provisions determining this mechanism of concurrent being in effect are set out in the Decree of the Cabinet of Ministers of Ukraine of May 23, 2011 No. 547 "Procedure for application of building regulations developed on the basis of the national technological traditions and building regulations harmonized with the normative documents of the European Union" and the DBN A1. 1-94: 2010 "Design of construction works according to Eurocodes. Basic provisions".

According to the aforementioned documents, the main direction for development of the regulatory framework in Ukraine is the implementation of national standards (norms developed on the basis of the national technological traditions) harmonized with the European Union normative framework at EUROCODE - the European unified building norms and regulations that have the status of European standards. The Eurocodes set common design criteria across the whole Europe, harmonize different national norms and regulations, and provide a single basis for a variety of scientific studies that facilitate the smooth exchange of products and services in the construction market.

According to the State Construction Standards (DBN) of Ukraine, DBN A.1.1-94: 2010. the Eurocode is a European standard for the design of building structures that contains the design requirements, and its main tasks are:

- to provide general criteria and design methods that meet the necessary requirements of mechanical resistance, stability and fire resistance at all types of loads, at that the requirements for the levels of safety (reliability) of buildings and constructions and the parts of those, with the aspects of durability and economy included, are a matter of the internal competence of the state;

14 Directive of the Cabinet of Ministers of Ukraine of January 30, 2019 No. 83-r "On approval of the 2019 action plan for the implementation of the Communication Strategy in the area of European Integration for 2018-2021" https://www.kmu.gov.ua/ua/npas/prozatverdzhennya-planu-zahodiv-na-2019-rik-z-realizaciyi-strategiyi-komunikaciyi-u-sferiyevropejskoyi-integraciyi-na-20182021-roki

${ }^{15}$ The Law of Ukraine “On Building Regulations” 1704-VI https://zakon.rada.gov.ua/laws/ show/1704-17 
- to serve as a basis at making contracts for design of buildings and constructions and the parts thereof, to facilitate the exchange of construction services (construction works and related engineering services), and to improve the functioning of the construction market;

- to provide a uniform understanding of the construction design process for the Ukrainian and foreign investors, customers, designers, contractors, etc.;

- to reduce the barriers and to facilitate the exchange of goods and services within the framework of construction activity of the participating States, to increase the competitiveness of the European construction firms, designers and manufacturers of structures and materials in the world market.

Introduction of European standards for the Ukrainian construction enterprises is of double importance. First, in the short and medium term, the companies will be forced to increase the expenses for the staff development and training, for tendering; besides that the effect of these documents males it possible for the European companies to enter the Ukrainian market on the basis of the rules being clear for them, to take part in tenders, this increases the level of competition in the industry. On the other hand, in the strategic perspective, training of personnel and removal of technical barriers for business activity (adaptation to European requirements) shall make it possible to develop the conditions for promotion of the domestic construction enterprises with entering international markets, and in addition to the European countries, from 2015, Kazakhstan and Belarus are going to to move to Eurocodes; and to gain additional competitive advantages at the domestic market as well.

Construction markets, according to the data of the Antimonopoly Committee of Ukraine, are attributed to the markets with a limited level of competition. However, the construction activity and production of building materials are for the year 2018 among the leaders in found out violations in the form of anticompetitive coordinated actions of economic entities by industries (69 in number) ${ }^{16}$. So, according to the share of products, works and services realized under conditions that exclude or substantially restrict competition was for the construction activity about $60 \%$. This is 1.57 times higher compared to the share of goods (works, services) realized under absolutely competitive conditions. In the construction sector (including the public works construction) in the markets having no structural restrictions on competition, only $25 \%$ of products, works and services were sold, while in the markets with oligopolistic structure $35.8 \%$, in markets with indications of domination of one economic entity and totally monopolized markets -

16 Report of the Antimonopoly Committee of Ukraine for the year 2018 http://www.amc.gov.ua/amku/doccatalog/document?id =148160\&schema=main 
$39.2 \%$. In this context, the EU-Ukraine Association Agreement will not only bring about the opportunities for finding new markets for construction companies, but it will increase as well the competition level in the domestic market.

\section{Implementation of the energy saving program as a priority direction for improving the economic security of the State}

Today, the main tendency in development of world energetics is the change of regional proportions of energy consumption, and the main task is to reverse the tendency of the outrunning growth of energy consumption by reducing the energy consumption of the economies. This is the most urgent task for developing countries with higher energy-intensive technologies compared to the developed countries.

There is an uneven increase of energy consumption in the world, with deepening regional energy imbalances: the highest rates are observed for the Asian countries, and especially for China, for which the energy consumption share has increased by $6 \%$ in recent years. Today, the number of countries and large regions with development not provided with their own energy resources is increasing. Beginning from the years 2005-2009, China, having surpassed the US, have captured the largest share of the world's energy consumption ( $12.45 \%$, compared to $11.39 \%$ of the US consumption); the share of energy consumption in Africa, Asia and the Middle East has grown, the share of the other region final energy consumption has decreased.

Despite numerous efforts, the structure of energy consumption in the world has not changed significantly over the last 25 years, and the dominant share of the most scanty resource - hydrocarbon fuel - continues to exist in the energy balance.

Today, the global economy is almost entirely dependent on the volumes of production of oil, natural gas, coal and other mineral fuels. The dependence of the developed countries on oil and natural gas imports is also projected to increase further. Oil will remain the main energy carrier in the coming decades, the share of natural gas will grow rapidly, and the share of coal will gradually decrease. It is likely that the maximum increment will be in solar, geothermal, wind and other alternative types of energy, though the cost of technologies and application of those is still very high. In electric power industry, the share of nuclear power plants is expected to decrease due to the fact that in the USA and Western Europe it is envisaged to replace the NPPs with the clean (gas) TPPs.

Many European and other developed countries are increasingly interested in alternative energy sources, and in some countries interest in nuclear energy is renewed. Though, along with that, hydrocarbon consumption 
globally has nowadays no serious alternative, this threatens scarcity of those with account of accelerated growth of energy consumption.

In 2019, the share of renewable energy sources in the world structure of energy consumption is still small compared to the traditional types of fuel and energy resources, with the largest share renewable energy in the EU countries (about $12 \%$ ). But at present there is a tendency of increase in the share of renewable energy sources in primary energy consumption of the European Union countries. Thus, the EU can take the leading position in the world in transition to the state-of-the-art energy technologies. This may be due to the fact that in the context of decrease in own traditional energy production and with constant increase in energy consumption, the EU countries are forced to import about $50 \%$ of the required energy resources.

Unlike most countries in the world where energy saving, though it is important, but is not more than one of the elements of economic and environmental policy, for Ukraine it is today a matter of survival. In market conditions and when entering the European and world markets, the energy component is a factor that substantially decreases the competitiveness of Ukrainian enterprises. At present, the main direction of reducing the energy intensity of products in all the sectors of economy is in formation of an effectively operating system of state management of the energy saving domain. The issues related to implementation of the energy-saving technologies and equipment in all the sectors of national economy (technological component) in the following areas are of great importance:

1. introduction of new energy saving technologies and equipment;

2. improvement of the existing technologies and equipment;

3. reduction of energy source losses;

4. improvement of product quality, improvement and reduction of losses of raw stock and materials;

5. replacement and selection of the most efficient energy sources.

According to the Energy Strategy of Ukraine for the period until 2035, developed in the context of the Sustainable Development Strategy "Ukraine 2020", approved by the Decree of the President of Ukraine, of January 12, 2015 No. $5^{17}$ providing, in particular, reformation of the power generation sector and implementation of the energy efficiency program within the stated pro-European vector of further development, the energy saving potential of the construction companies is not large (Table 1).

\footnotetext{
${ }^{17}$ Energy Strategy of Ukraine for the period until 2035 [Electronic source] - Access mode: https://zakon.rada.gov.ua/laws/show/605-2017-\%D1\%80
} 
Table 1

Energy saving potential of construction due to technical (technological)

factor (calculated by the author according to the data)

\begin{tabular}{|c|c|c|c|c|}
\hline Sector & 2010 & 2015 & 2020 & 2030 \\
\hline \multicolumn{5}{|c|}{ Fuel, million tons of reference fuel } \\
\hline Building and construction & 0.35 & 0.64 & 0.81 & 1,02 \\
\hline $\begin{array}{l}\text { Percentage of construction activity in } \\
\text { the total energy saving potential }\end{array}$ & $0.91 \%$ & $0.96 \%$ & $0.90 \%$ & $0.83 \%$ \\
\hline \multicolumn{5}{|c|}{ Electricity, billion $\mathrm{kWh}$} \\
\hline Building and construction & 0.04 & 0.1 & 0.1 & 0.18 \\
\hline $\begin{array}{l}\text { Percentage of construction activity in } \\
\text { the total energy saving potential }\end{array}$ & $0.23 \%$ & $0.26 \%$ & $0.26 \%$ & $0.25 \%$ \\
\hline \multicolumn{5}{|c|}{ Heat, million Gcal } \\
\hline Building and construction & 0.08 & 0.14 & 0.17 & 0.40 \\
\hline $\begin{array}{l}\text { Percentage of construction activity in } \\
\text { the total energy saving potential }\end{array}$ & $0.22 \%$ & $0.21 \%$ & $0.19 \%$ & $0.20 \%$ \\
\hline
\end{tabular}

Given that the construction industry provides reproduction of productive and nonproductive fixed assets, the role of construction enterprises in the state's energy sawing program can be considered as decisive. For the construction companies, this means that those have to refocus their activities on energy efficient materials, technologies, development of markets of energy saving construction in the residential and industrial sectors of the economy. The markets are at that divided into two types - reconstruction of existing buildings and designing new buildings with optimal energy consumption.

Another important step is the implementation of the European Union's experience in standardization of energy efficiency of buildings and constructions (the European Directive on the energy performance of buildings - Energy Performance of Building Directive, EPBD). This Directive is supported by more than $40 \mathrm{EN}$ standards, including those that characterize the total energy consumption of building, those standards determine the methods for calculation of energy consumption by individual engineering systems and the building as a whole, are determinative for the load on the heating and cooling of the building, state the rules for choosing the conditions of functioning of the buildings, with provision of monitoring and verification of marking and certification of energy efficiency of buildings.

Harmonization of national standards with account of the current base of construction regulations will create regulatory and methodological provisions for certification of energy efficiency of buildings and constructions in accordance with the Law of Ukraine "On Energy Saving". 


\section{Ecological focusing of construction}

Widespread in the EU countries are the directions of construction based on new environmental technologies, application of environmentally friendly materials and raw stock the use of which allows to reduce greenhouse gas emission to atmosphere, production of improved materials. Sustainable construction, along with improving the energy efficiency of buildings, is a part of the Global Green New Deal (GGND) direction, aimed at fostering the recovery of financial system, overcoming the recession in the economy, shifting the after-crisis development towards ecologically friendly and sustainable development, at job gains, according to the United Nations Environment Program (UNEP). To this end, a package of public investments, fiscal stimulus, pricing reforms is proposed to shift towards ecologically-oriented "green" economy, to create the appropriate infrastructure and increase employment in the transformed sectors of the economy. Compared to the traditional construction, the use of the "green standards" is more expensive, though this is a promising way to increase the competitiveness of construction companies and to reduce the negative effect of their activities on the environment.

Green Building Certification is a process of evaluating the design documentation of a building on compliance with the criteria of the green building standard, based on a scoring system of evaluation carried out by an authorized executive authority with issuing for the building contract specifier, the owner of the building having obtained the appropriate number of points, a certificate of green building.

The Green Building Certificate is the document that confirms the certification. The certification is voluntary, its criteria determine the compliance of the building with green building standards, namely:

- ecological criterion that includes calculated, with account of lessons learned from international methods, volumes of man-caused greenhouse gas emission, characteristics of influence on the ozone layer, indicators of internal microclimatic parameters of the building, indicators of quality and efficiency of drinking water use in the water supply system and conditions of water drain, outer surface use, characteristics of waste generation, sorting and utilization;

- economic criterion, including the amount of costs associated with the operation of the building, energy efficiency indicators of office building;

- a functional criterion that includes the thermal performance characteristics for the building in winter and summer seasons, acoustic characteristics, characteristics of natural and artificial lighting, ventilation, air conditioning, characteristics of temperature and solar exposure, accessibility for the users, characteristics of changeability; 
- a technical criterion that includes the fire safety indicator, indicator of noise exposure, humidity level in premises, an indicator of the convenience of cleaning and maintenance of the building, indicators of the solid waste content at demolition or dismantling of the building;

- location criterion that includes a measure of the degree of risks associated with the location, characteristics of traffic connectivity, of infrastructure development, location conditions.

There are many standards in the world that evaluate the energy performance of buildings - LEED, BREEAM, CASBEE, GREEN STAR and others. It is possible to apply different certification systems to new buildings and to existing ones as well, there are distinguished between the nominal and functional, mandatory (the European Union Energy Performance of Buildings Directive) and voluntary systems (BREEAM, LEED). There are more than ten standards highlighted for the voluntary certification systems in the world. Most of those are national in nature (Japan - CASBEE, Australia - GREEN STAR, NABERS, France - HQE, Germany - DGNB, etc.). The BREEAM (UK) and LEED (US), as well as DGNB's GSBC, are actively present at international market.

The international standards have stood out from a number of national standards through healthy market competition and are represented by two leading schemes - LEED and BREEAM. The choice usually depends on the country of construction or on the project owner's expectations. So, the US investors mostly get the LEED certificate and the European investors - the BREEAM one.

\section{Deregulation in construction activity}

Today, the construction sector in Ukraine undergoes substantial transformation at the organizational, legal and scientific and technical levels, one of the directions of those transformations is deregulation in construction activity. Regulation of construction activity by the state control and supervision instruments alone does not provide or to full extent the quality of products, the responsibility to respect consumer rights, and does not guarantee the absence of unfair market participants. Among specific examples of such deregulation and decentralization initiatives are the Law of Ukraine "On Regulation of Urban Development", the Law "On Amendments to Some Legislative Acts of Ukraine on Simplifying Business Conditions (Deregulation)" aimed at simplification of the procedures in construction industry. Those legislative proposals amend a large number of procedures in the construction sector in order to simplify the procedure, with obtaining documents for commencement of construction works and commissioning of facilities included, with the terms of issuance of technical specifications, submission of declaration on implementation of preparatory 
and construction works, the system of State supervision over decisionmaking in the area of urban development planning and implementation of architectural and constructional control, the mechanism of contestation of such decisions by the project owner. The concept of simplification of business operations involves removal of licenses, permits, regulations, certificates, prescriptions, with reduction of the periodicity of inspections and winding up respective units and national regulatory authorities. In addition, it is proposed to redistribute the functions for provision and control of implementation among different local authorities.

\section{Systematic effect of the financial and economic crisis, hostilities at the east of the State on the economy}

The crisis phenomena, having led to a decrease in production and a decrease in household income, have made a very negative impact on the economic state of the construction industry. Moreover, construction has turned out to be one of the most vulnerable sectors of economy at crisis. The slowdown in construction in Ukraine has began from the beginning of 2008, and by the end of the year it has become an abrupt decrease; and even in 10 consecutive years construction still has not reached the level of the year 2008.

The main negative factors that have determined the indicators in the construction sector are:

1. decrease in demand for construction products from both, population (housing development) and the public and private sectors (construction of objects for industrial, commercial, social purposes);

2. crisis in the financial sector of the country, lack of financial resources. During the last years before the crisis, high dependence of construction companies on the financial market was observed. Most of those companies worked on the basis of the borrowed resources of population, of institutional investors, banks, and thus deterioration of the conditions of access to borrowed funds became a significant disadvantage for these enterprises;

3. residential real estate price crash resulted in unprofitability of a large number of projects, the government programs aimed at supporting the construction of unfinished objects, of social and affordable housing are moving slowly, often with lack of funding for those;

4. reduction of paying capacity of partner companies, due to the shortage of liquidity the process of settlements is complicated;

5. the increase in prime cost caused by growth in the cost of energy sources and the drop in the hryvnia exchange rate has led to decrease in profitability of the main activity; 
6. temporary shutdown of investment activity by domestic enterprises under conditions of political and economic uncertainty, even the companies being able to invest, into construction as well, have slowed down their investments.

\section{Digital transformation of economy}

Digitization of all the spheres of activity of the State - from getting services and up to controlling the work volumes by means of cameras for supervision and drones, carrying out the big data analysis based on the basis of the Big-Data technology, storing information in «cloud» storage services, etc. Currently, the participants of the investment and construction process can monitor the progress of construction on-line ${ }^{18}$, without leaving the office, can make changes and updates to project in real-time mode, those immediately become open to other participants (BIM modeling) ${ }^{19}$, can control the quality and the volume of construction work by means of drones $^{20}$. The impact of the State on the economy of the country is to take place through harmonizing the policy of digitization with scientific and technical, budgetary, monetary and credit, industrial and foreign economic policies, provided that integration of interests and coordinated relationship between the society, the State, government, business, community and scientific institutions is achieved. It should by taken into account that the digital economy provides unprecedented opportunities for businesses and organizations to freely choose partners and consumers, facilitates market entry and promotion, substantially reduces transaction costs, facilitates decentralization, etc. Therefore, the digitization process will take place even in the case of State non-involvement or resistance, since it is a sign of continuous development of the economic system and means of ts transition to a new, qualitatively different level. In order for the digital transformation of the economic system to be managed, it is necessary to combine the efforts of scientific schools, of the participants of the investment-construction process, citizens, the State to achieve a balance of interests of all those groups at implementation of measures for digitization of economy.

The effective strategy for development of digital economy and construction sector is to be based on the productive potential of education and science, on the

${ }^{18}$ Zeltser R.Ya., Bielienkova O.Yu., Novak E., Dubinin D.V. Digital transformation of processes of resource-logistical and organizational-structural support of construction. Science and innovation. 2019, No. 15(5), P. 38-51.

${ }_{19}$ Nikolaiev V. P. Information modeling of buildings: imperatives of optimization of construction and operation process / V. P. Nikolaiev, T. V. Nikolaieva // Construction operations. - 2015. - No. 59. - P. 17-26.

${ }^{20}$ Zeltser R.Ya, Kolot M.A, Panasiuk I.O. The practice of using drones at implementation of construction projects in Ukraine. The ways to increase the efficiency of construction operations under the conditions of formation of market relations. 2018. No. 35. P. 151-154. 
development of new research studies, elaboration of new organizational solutions and connections, technologies, business processes, etc.

\section{CONCLUSIONS}

Consideration of the above factors will make it possible for the construction enterprises to elaborate their own development strategies more soundly, to identify the risk factors and evaluate their own capabilities. In view of the tendency of the crisis to continue, it is now important for construction companies to abandon the strategy aimed at increasing the volume of work and to focus on preparation for the economic recovery of the country. The key tasks at that are to be in retaining the market share, work on creating the image of a reliable partner, maintenance of own economic stability and strength.

\section{SUMMARY}

Ukraine's strive for integration to the European economic system has necessitated the restructuring and reorientation of the construction industry in order to increase the competitiveness of domestic enterprises on the principles of sustainable development and integration into the world economy.

This has necessitated the improvement of the regulatory framework, legal and technical regulation, standardization, certification, conformity assessment, the State supervision and control aimed at protecting the interests of the country, including the improvement of competitiveness of construction industry enterprises in order to ensure high quality, security of real estate objects and export orientation of enterprises.

Implementation of energy efficient technologies and economical consumption of energy resources, energy carriers from renewable energy sources and alternative fuels, adaptation of low-waste and non-waste technologies, use of secondary resources, use of facilities for production of non-traditional and renewable energy sources are objectively required for Ukrainian economy, along with meeting the requirements of ecological standards.

One of the trends in development of construction is decentralization and deregulation of construction, this is aimed at simplifying the business operations of individual companies and transferring powers of authority to local governments.

Analysis of the current state of digital transformation of construction activity shows that digitization is a rapid, irreversible, constant process of development of economic systems in the world. In Ukraine, the process of digitization has already begun at the level of individual economic operators and the level of regions, cities, states as well. In construction industry, the 
process of digital transformation progresses due to introduction of new information technologies, the Internet of Things, drones and more. This process requires support and regulation by the State. Interventions proposed for improvement of the mechanism of digital transformation of construction industry will help to manage the process of digitization on a controlled basis.

Further liberalization of the economy and reduction of doing business barriers, digitization of activity of construction companies are positive trends, while continued effect of socio-economic and financial crises, of armed hostilities at the east of the country are destructive factors. With account of those factors it is possible to build a construction sector development strategy that takes into account the key factors and is as close to real trends as possible. An effective strategy of the construction industry development should be based on the productive potential of education and science, development of new scientific studies, with generation of new organizational structures, interconnections, technologies, business processes, and more.

\section{REFERENCES}

1. The Law of Ukraine "On Regulation of Urban Development" with amendments and supplements [Electronic source] / Legislation of Ukraine. Verkhovna Rada of Ukraine. - Access mode: http://zakon4.rada.gov.ua/ laws/show/3038-17

2. The Law of Ukraine "On Building Regulations» [Text] / Bulletin of the Verkhovna Rada of Ukraine (BVR), 2010. No. 5, P. 41.

3. The Law of Ukraine "On Energy Saving" [Electronic source] / Legislation of Ukraine. Verkhovna Rada of Ukraine. Official Website Access mode http://zakon2.rada.gov.ua/laws/show/74/94-\%D0\%B2\% D1\%80

4. The Law "On Amendments to Some Legislative Acts of Ukraine on Decentralization of Powers in the Field of Architectural and Constructional Control and Improvement of Urban Development Legislation" [Electronic source] - Access mode http://search.ligazakon.ua/l_doc2.nsf/ link1/NT0925.html

5. The Law "On Amendments to Some Legislative Acts of Ukraine on Simplifying Business Conditions (Deregulation)" [Electronic source] Access mode http://w1.c1.rada.gov.ua/pls/zweb2/webproc4_1? pf3511=53076

6. Decree of the Cabinet of Ministers of Ukraine of 23.05.2011 No. 547 "Procedure for application of building regulations developed on the basis of the national technological traditions and building regulations harmonized with the normative documents of the European Union"

7. DBN A1. 1-94: 2010 "Design of construction works according to Eurocodes. Basic provisions"./Minregionbud. - K.: 2012 - 22 p. 
8. Report of the Antimonopoly Committee of Ukraine for 2013 [Electronic source] - Access mode http://www.amc.gov.ua/amku $/$ doccatalog $/$ document?id=103172\&schema=main

9. European Directive on the energy performance of buildings EPBD2010 (Energy Performance of Building Directive) [Electronic source] Access mode: http://www.bre.co.uk/filelibrary/Scotland/Energy_ Performance_of_Buildings_Directive_\%28EPBD\%29.pdf

10. Energy strategy of Ukraine for the period until 2030 [Electronic source] - Access mode: https://zakon.rada.gov.ua/laws/show/n0002120-13

11. Global Green New Deal. UNEP report. March 2009. [Electronic source] - Access mode: www.unep.org/greeneconomy

12. Bielienkova O.Yu. The impact of economic crisis on the financial state of enterprises of the type of activity "construction" / Bielienkova O.Yu. // Construction production. 2010. - Issue 52. - P. 16-20.

13. Bielienkova O.Yu. Economic Evaluation of Energy Efficiency Improvement Measures / Bielienkova O.Yu., Ostapenko I.O. // Construction production. Interagency Scientific and Technical Collection - 2013. Issue 55. - P. 28-31.

14. Goiko A.F. Efficiency of investment of reconstruction and technical re-equipment of existing enterprises / Goiko A.F. // Ways to increase the efficiency of construction under conditions of formation of market relations: Coll. Sci. Proceedings - K .: KSTUCA, 2009. - P. 64-74.

15. Sorokina L.V. Study of impact of macroeconomic regulators on the dynamics of capital accumulation in the construction sector of Ukraine / L.V. Sorokina // Actual problems of economy. - 2012. - No. 6. - P. 69-81. Access mode: http://nbuv.gov.ua/UJRN/ape_2012_6_10

16. An econometric toolkit for managing financial security of a construction company: [monogr.] / L. V. Sorokina, S. P. Stetsenko, A. F. Goiko, K. V. Izmailova, T. Yu. Tsyfra [et al.]; under sci. ed. of Doctor of Economics, prof. L. V. Sorokina. - K. : Kyiv National University of Construction and Architecture; Kryvyi Rih: Published SEP Cherniavskyi D. O., 2017. - P. 4-26.

17. Ryzhakova G. Implementation of principles of biospheric compatibility in the practice of ecological construction in Ukraine [Текст] / D. Chernyshev, I. Ivakhnenko, G.Ryzhakova, K.Predun // International Journal of Engineering \& Technology - UAE: Science Publishing Corporation, 2018- Vol 10. No 3.2: Special Issue 2 - pp. 584-586.

18. Tetyana Marchuk, Dmytro Ryzhakov, Galyna Ryzhakova and Sergiy Stetsenko (2017). Identification of the basic elements of the innovationanalytical platform for energy efficiency in project financing. Investment Management and Financial Innovations Vol. 14(4), pp. 12-20.

19. Maksymov A. S, Dovganiuk V.M, Vakhovych I.V, Tsyfra T.Yu. Theoretical and economic rationale for the measures to improve the energy 
efficiency of non-industrial objects. // - "Green" Economy - Movement Towards Sustainable Development: Collection of Materials - K.: ScientificResearch Economic Institute of the Ministry of Economic Development and Trade of Ukraine, 2013. - P. 113-116.

20. Energy Efficiency in the Municipal Sector. A manual for officials of local self-government / Maksimov A.S., Vakhoviych I.V., Gutnichenko T.P., Babicheva P.Ya., Vakulenko N.M., Tsyfra T.Yu. Et al. - Association of Ukrainian Cities under the USAID DIALOGUE Project, 2015. -184 p.

21. Belenkova O.Yu. Tendencies of construction industry development as factors of formation of strategic competitiveness of construction enterprises. // Construction production. Interagency Scientific and Technical Collection - 2014. - Issue 57. - P. 24-30.

22. Chupryna Yu. Informational and analytical supply of project simplemented byregional construction class // Innovative Solutions In Modern Science, № 6(25), 2018.

23. Goiko A.F. An Empirical Assessment of the Security of Economic Development of Construction Enterprises: A European Aspect / A.F. Goiko, L.V. Sorokina, V.A. Skakun // Coll. Sci. Proceedings "Ways to increase the efficiency of construction under conditions of formation of market relations" - Issue 40. Economic - K.: KNUCA, 2019. - P. 17-18.

24. Tsyfra T.Yu. Certification Systems - new realities of Ukraine / Tsyfra T.Yu., Derkach E.V. // Energy efficiency in construction and architecture - Scientific and Technical Collection. - Issue 8. K. : KNUCA, 2016. - P. 403-409.

25. Izmailova K.V. Ecological support of reserves as a factor of efficiency of use of fixed assets of construction company / K.V. Izmailova // Ways to increase the efficiency of construction : Coll. Sci. Proceedings issue 36. - 2018. - P. 3-7.

26. Tsyfra T. Yu. Practical experience of implementation of international construction contracts in Ukraine [Text] / T. Yu. Tsyfra // Construction production. - K., 2017. - Issue No. 63/2. - P. 78-85.

\section{Information about the author: Bielienkova O. Yu.,}

$\mathrm{PhD}$ in Economics, Associate Professor, Associate Professor at the Department of Construction Economics, Kyiv National University of Construction and Architecture 31, Povitroflotsky ave., Kyiv, 03037, Ukraine 


\section{STUDY OF THE TECHNOLOGY OF STRENGTHENING BRICK WALLS BY EXTERNAL REINFORCEMENT}

\section{Molodid O. S.}

\section{INTRODUCTION}

From the analysis of technical inspection reports developed by the State Enterprise "V.S. Balitsky Research Institute of Building Production", it has been established that $85 \%$ of brick buildings over 30 years of age have cracks on their walls. Such cracks appear on one side of the wall or can be through-thickness, diagonal, horizontal or vertical, through brick joints and with brick breaks. As a rule, their width ranges from $0.1 \mathrm{~mm}$ to $70 \mathrm{~mm}$. (fig. 1).

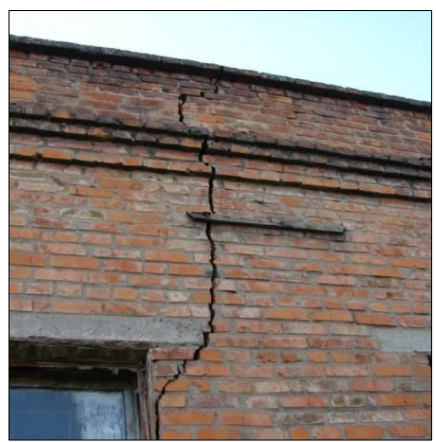

Fig. 1. A diagonal crack on a brick wall with a width ranging from 25 to $45 \mathrm{~mm}$

The causes for brickwork fracture are ${ }^{1}$ :

- increased load on these constructions due to the replacement or strengthening of upper constructions (heightening, adjacent accommodation) or replacement of technological equipment (file benches, lifts, escalators, cranes etc.) by items whose mass exceeds the mass of the ones used before the reconstruction;

- loss of bearing strength caused by operation: dynamic load, corrosive operational environment or atmosphere, improper operation (corrosive

\footnotetext{
1 Савйовський В. В. Реконструкція будівель і споруд / В.В.Савйовський. - К.: Видавництво Ліра-К, 2018. - 320 с.
} 
substances spill, leaks in water supply systems and sewage, weather), random damages, accidents.

In accordance with the National Standards of Ukraine DSTU-N B V.1.2-18:2016 ${ }^{2}$ and DSTU B V. 3.1-2:2016, vertical and diagonal cracks crossing not more than two courses of masonry and other cracks with the width under $0.5 \mathrm{~mm}$ need either injection or caulking. The walls with vertical and diagonal cracks whose width ranges from 0.5 to $50 \mathrm{~mm}$ require filling and strengthening or re-laying of brickwork.

Normally, strengthening of masonry constructions requires much less costs than replacement thereof; however, it calls for a responsible and highly qualified approach to the carrying out of a set of complicated construction works.

The main objective of strengthening of masonry structures is to increase its bearing strength and reinforcing elements after their performance has been reduced due to the influence of various factors or in case additional strength needs to be added to the elements.

The decision on the technical feasibility and economic efficiency of strengthening masonry construction in each individual case is taken with due consideration of their state and performance characteristics.

Current regulations ${ }^{1}$ and technical literature ${ }^{4,5}$, offer the following ways of strengthening or restoring the bearing strength of brick walls:

- full or partial replacement of the existing brickwork;

- injection of cracks;

- introduction of various strengthening elements;

- external reinforcement.

The most efficient ways of strengthening masonry structures is the installation of ferrocement, reinforced brick, reinforced concrete or steel casings ${ }^{3}$.

Currently, external reinforcement, i.e. steel plates welded into a frame and fixed to a wall with anchors (fig. 2) is widely used in Ukraine for strengthening brick walls. However, the technology of such strengthening is complicated and labor-intensive, as it is connected with the need to perform

2 ДСТУ-Н Б В.1.2-18:2016 Настанова щодо обстеження будівель і споруд для визначення та оцінки їх технічного стану. - Київ: ДП «УкрНДНЦ», 2017. - 47 с.

${ }^{3}$ ДСТУ Б В.3.1-2:2016 Ремонт і підсилення несучих і огороджувальних будівельних конструкцій та основ будівель і споруд. - Київ: ДП «УкрНДНЦ», 2017. - 72 с.

4 Савйовський В. В. Реконструкція будівель і споруд / В. В. Савйовський. - К.: Видавництво Ліра-К, 2018. - 320 с.

5 СТО 221 НОСТРОЙ 2.9.142-2015 Восстановление и повышение несущей способности кирпичных стен Проектирование и строительство. Правила, контроль выполнения и требования к результатам работ. - М.: «Издательство «БСТ», 2013. - 114 с. 
welding and fix the plates with anchors, especially when these works are performed at heights.

It should be mentioned that when strengthening long wall constructions, difficulties may arise with stringing horizontal steel plates to engage them in operation. Therefore, sometimes the plates meant for strengthening sag and overload the construction of the walls.

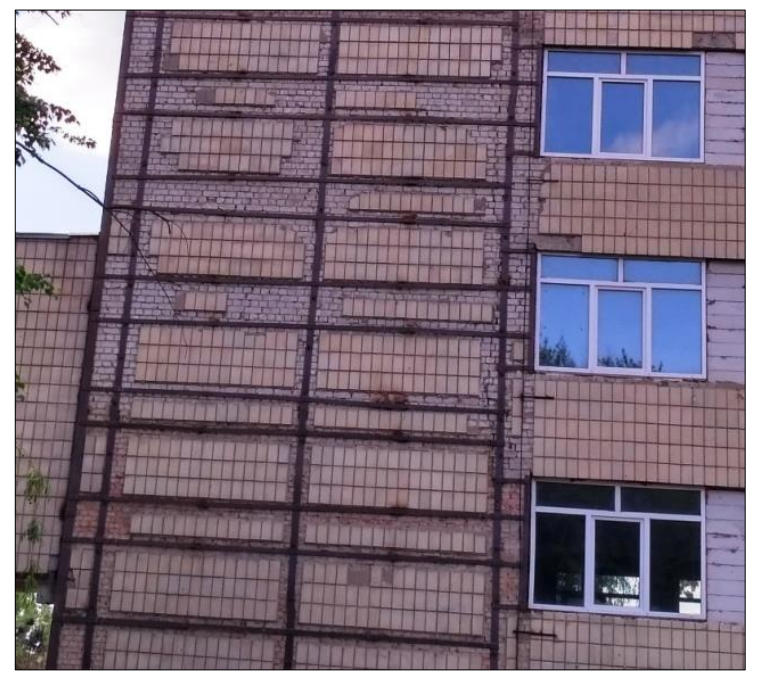

Fig. 2. Strengthening of brick walls with external reinforcement, i.e. steel plates

It should be mentioned that works of foreign scholars, 7 provide extensive coverage to design and technology solutions for strengthening brick walls with external reinforcement using composite fibers, plates (lamellae) or nets fixed to the wall surface.

The technology of strengthening constructions with composite fibers lies in gluing of high-strength plates with a special epoxy glue or microcementbased glue onto the construction surface. The strengthening is performed on the prepared surface with pre-coated base. Both strengthening of bending constructions in the tension areas and pre-heel areas in the action areas of lateral forces and compression elements and beam columns is possible.

${ }^{6}$ Angelo Garofano. Structural behaviour of masonry walls strengthened with mortar layers reinforced with FRP grids. Master's Thesis. - Czech Republic, 2011. - 124 p.

${ }^{7}$ Saman Babaeidarabad. Masonry walls strengthened with fabric-reinforced cementitious matrix composite subjected to in-plane and out-of-plane load. Dissertation. - Coral Gables, Florida, 2013. - 147 p. 
Similar research has been conducted by A.N. Kostenko ${ }^{8}$, who carried out a series of compression tests of brick piers reinforced by carbon fabric bandages. In the course of these tests, it was established that the bearing strength of brick piers can be increased nearly twofold as compared to the reference. Samples were tested by compression and bending. The test results demonstrated that, when carbon fiber is used, the laying strength under compression increases approximately 2-2.4 times (depending on the reinforcement pattern of the sample). The reinforcement patterns are shown in figure 3.

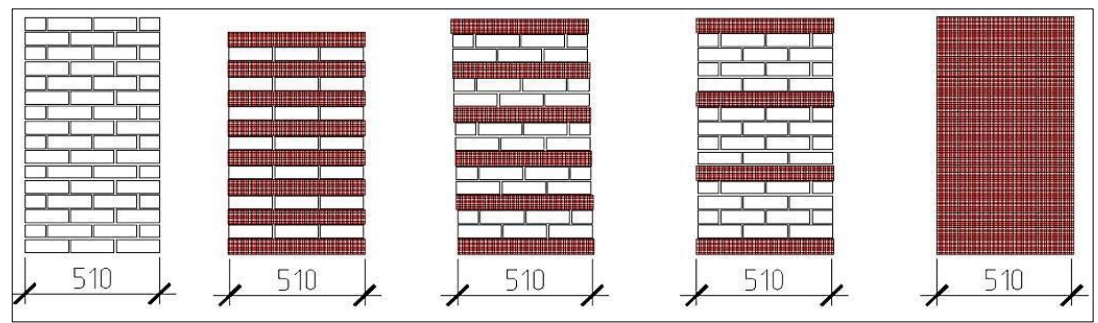

\section{Fig. 3. Patterns of brick piers reinforcement with composite grids during sample compression tests}

The top efficiency was shown by the samples completely covered with grids. As per the tests, the relative strength increased 2.6 times. However, a number of unsolved issues is connected with this configuration of strengthening. Such strengthening of the construction excludes brickwork vapor permeability. Besides, the wrecking of the brickwork becomes random, as the ability to control crack formation is lost.

It should be noted that information on such ways of strengthening brick walls is virtually unavailable in Ukrainian scientific, technical and regulatory literature.

In view of the above, the author made a decision to research the technology of strengthening brick walls with external reinforcement glued to the reinforced constructions, where domestic materials were used.

\footnotetext{
${ }^{8}$ Костенко А. Н. Прочность и деформативность центрально и внецентренно-сжатых кирпичных и железобетонных колонн, усиленных угле- и стекловолокном. Автореферат диссертации на соискание ученой степени кандидата технических наук, Спец. 05.23.01. M., 2010. 29 c.
} 


\section{Experimental tests, Stage I.}

At this stage, experimental tests were conducted to establish the dependence of the strength of adhesion of the reinforcement element glued to the brick to on the influence of such technological factor as base preparation.

The tests was conducted in two series, each of which consisted of five hollow type M100 clay bricks.

The main task of these experimental tests was to define the strength of adhesion with the base of the metal plates glued (the attachment area was $25 \mathrm{~cm}^{2}$ ) to a prepared lateral surfaces (stretchers) of the bricks. The surfaces of separate bricks were prepared by soaking with Consolid-1 deeply penetrating epoxy-based primer manufactured by COMPOSIT LLC.

In the first series of the tests, one stretcher of the test brick was divided into three equal parts. No manipulations were made with the first part. The second part was evenly covered with a single coat of Consolid-1 primer with a brush (with the rate of application $370 \mathrm{~g} / \mathrm{m}^{2}$ ). The third part was first covered with one coat of Consolid-1 primer $\left(370 \mathrm{~g} / \mathrm{m}^{2}\right)$, and 24 hours later with another coat of the same primer at the rate of application of $200 \mathrm{~g} / \mathrm{m}^{2}$.

In the second series of the tests, one stretcher of each tested brick was divided into two parts. The first part was covered with ten coats of Consolid1 primer with the rate of application for each coat $300 \mathrm{~g} / \mathrm{m}^{2}$. Each subsequent coat of primer was applied after the previous had soaked into the brick. The same manipulations were made with the second part of the bricks, but the number of coats was increased up to 30 .

Twenty-four hours after the last coat of primer had been applied, a metal plate was glued to on each separate part of the prepared and unprepared brick surface (fig. 4). The plates were glued with EDMOK epoxy-based glue manufactured by COMPOSIT LLC.

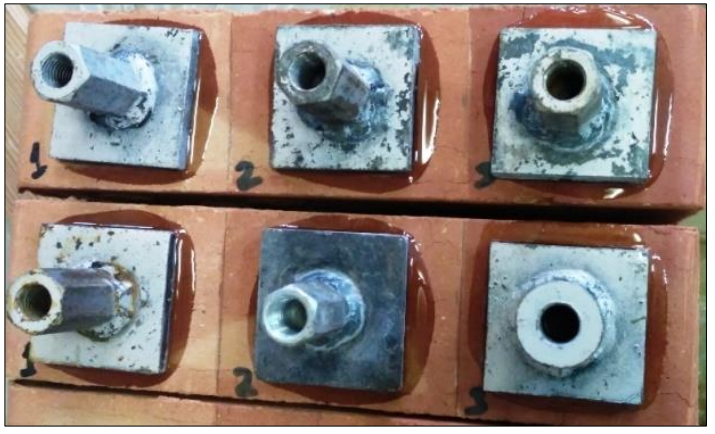

Fig. 4. Plates glued to bricks stretchers in the first series of tests 
In two days after the plates were glued, a coat of glue was cut along the perimeter of the plates down to the brick, after which the plates were torn away with the help of an adhesiometer.

The results demonstrated that all metal plates were torn with fragments of the bricks, and the size of these fragments and the force with which the plates tore off depended on the technology of the base preparation (fig. 5) (table 1).
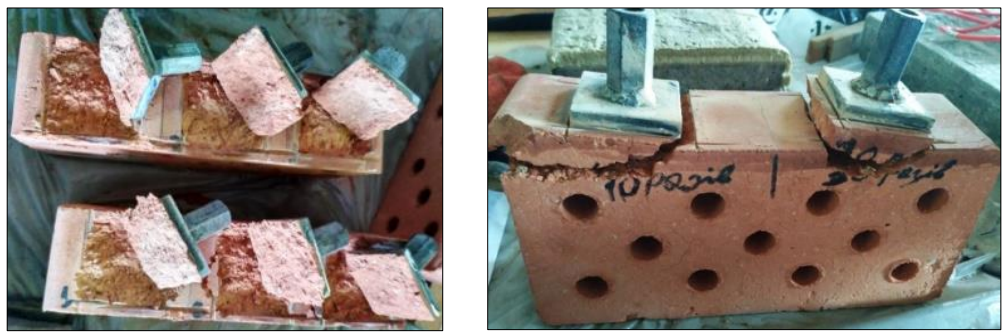

Fig. 5. Torn-off plates with fragments of bricks

Table 1

Test results for tearing off plates glued to bricks

\begin{tabular}{|c|c|c|c|c|c|c|}
\hline \multirow[t]{2}{*}{ No. } & \multirow[t]{2}{*}{$\begin{array}{c}\text { Test } \\
\text { series }\end{array}$} & \multirow[t]{2}{*}{$\begin{array}{c}\text { Test } \\
\text { number }\end{array}$} & \multirow[t]{2}{*}{$\begin{array}{l}\text { Application rate } \\
\text { of Consolid-1 } \\
\text { primer for base } \\
\text { preparation, } \mathrm{g} / \mathrm{m}^{2}\end{array}$} & \multicolumn{2}{|c|}{$\begin{array}{l}\text { Average force of } \\
\text { tearing plates off } \\
\text { bricks }\end{array}$} & \multirow{2}{*}{$\begin{array}{c}\text { Thickness of } \\
\text { the torn-off } \\
\text { brick } \\
\text { fragment, mm }\end{array}$} \\
\hline & & & & MPa & $\%$ & \\
\hline 1 & \multirow{3}{*}{1} & 1 & 0 & 1.09 & 100 & $1-3$ \\
\hline 2 & & 2 & 370 & 1.21 & 111.0 & $2-4$ \\
\hline 3 & & 3 & 570 & 1.32 & 121.1 & $2-5$ \\
\hline 4 & \multirow[t]{2}{*}{2} & 4 & 3000 & 2.26 & 207.3 & $5-8$ \\
\hline 5 & & 5 & 9000 & 2.81 & 257.7 & $7-10$ \\
\hline
\end{tabular}

The test results (table 1) were used to build a histogram (fig. 6) of the average force of tearing plates off the bricks at different application rates of the primer used for base preparation.

The analysis of the experimental test results enables us to state that preparing bricks surface before reinforcement elements are glued to it influences the strength of adhesion with the base. When it permeates the brick structure, Consolid-1 primer strengthens it, whereby, when a metal plate is torn off, a fragment of the brick is torn of with it, and the tearing dept of the fragments grows with the increase of primer application rate when applying it to the brick surface. 


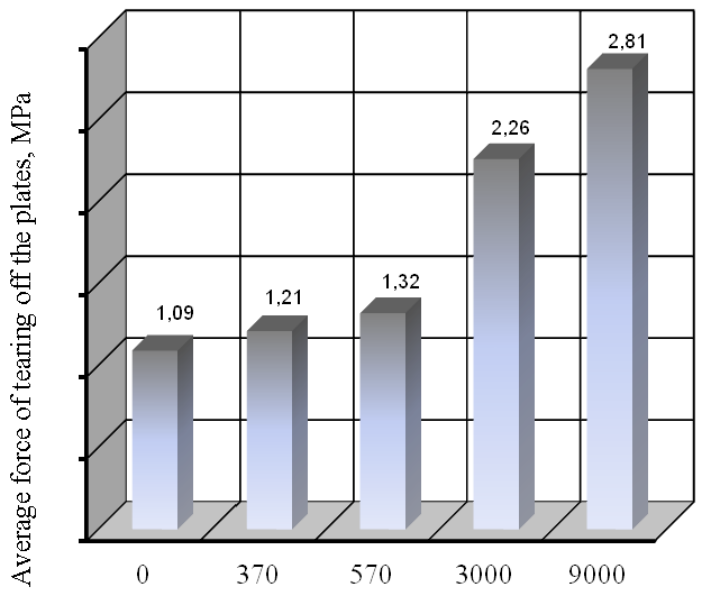

Primer application rate for base preparation, $\mathrm{g} / \mathrm{m}^{2}$

\section{Fig. 6. Histogram of the average force of tearing plates off the bricks at different primer application rates for base preparation}

For example, the average force of tearing off a plate from a brick with an unprepared surface was $1.09 \mathrm{MPa}$, and the average force of tearing off of plates from bricks whose surface was covered with $570 \mathrm{~g} / \mathrm{m}^{2}$ of primer is $1.32 \mathrm{MPa}$, which is $21.1 \%$ more.

It should be mentioned that application of $9,000 \mathrm{~g} / \mathrm{m}^{2}$ of primer on the brick surface raises the average tearing force of plates to $2.81 \mathrm{MPa}$, which is $157.7 \%$ more as compared to the force of tearing off plates from untreated bricks.

\section{Experimental tests, Stage II}

The main task of this stage of experimental tests was to find effective methods of strengthening of brick constructions with external reinforcement. The bricks were reinforced by gluing steel plates or carbon fiber strips to their lateral surfaces (stretchers). The surface of separate bricks was prepared by soaking with Consolid-1 deeply-penetrating primer manufactured by COMPOSIT LLC. Preliminary marked areas of adhesion of strengthening elements were evenly covered with tree coats of primer with a brush with a total rate of application of $1,100 \mathrm{~g} / \mathrm{m}^{2}$.

Twenty-four hours after the last coat of primer had been applied, strengthening elements were glued to the prepared and unprepared brick surfaces (fig. 7). The elements were glued with EDMOK epoxy-based glue manufactured by COMPOSIT LLC. 
The following methods of brick strengthening are foreseen (fig. 7):

1. non-strengthened bricks;

2. steel plates (30 $\mathrm{mm}$ in width, $2 \mathrm{~mm}$ in thickness) fixed with glue and mechanically secured with anchors;

3. carbon fiber strips ( $30 \mathrm{~mm}$ in width, with density of $300 \mathrm{~g} / \mathrm{m}^{2}$ ) fixed with glue;

4. steel plates (30 $\mathrm{mm}$ in width, $2 \mathrm{~mm}$ in thickness) fixed with glue;

5. brick surfaces coated with primer, with steel plates $(30 \mathrm{~mm}$ in width, $2 \mathrm{~mm}$ in thickness) glued to them 24 hours later. The plates were additionally pressed to the bricks;

6. brick surfaces coated with primer, with carbon fiber strips $(30 \mathrm{~mm}$ in width, with density of $300 \mathrm{~g} / \mathrm{m}^{2}$ ) glued to them 24 hours later;

7. brick surfaces coated with primer, with two carbon fiber strips (30 mm in width, with density of $300 \mathrm{~g} / \mathrm{m}^{2}$ ) glued to each of the surfaces 24 hours later.

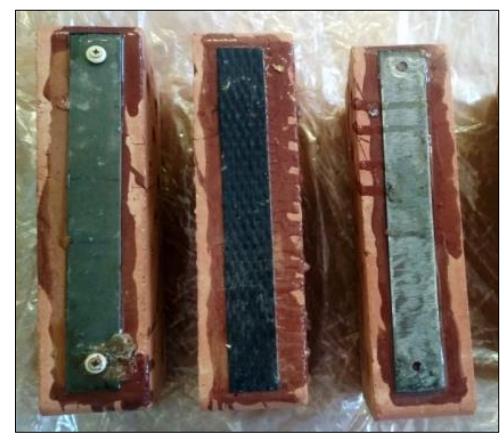

№ 2 № 3 № 4

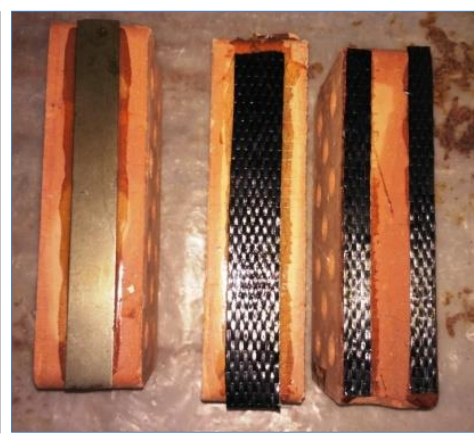

№ 6

№ 7

Fig. 7. Bricks strengthened by various methods

Two days after gluing the strengthening elements, the bricks were tested for bending strength. The tests were conducted on hydraulic press PSU-10.

For a static diagram, the tests were conducted as for a free-ended beam with $220 \mathrm{~mm}$ width. The bricks were loaded with concentrated force in the middle of the brick (fig. 8).

The load was applied to the bricks in stages with gradual load increase of $20 \mathrm{~kg}$ at each stage with 1-minute delay. The tests were conducted until the bricks lost their strength. The results of the experimental tests are given in table 2. The fracture patterns of strengthened or non-strengthened bricks are shown on fig. 9 . 

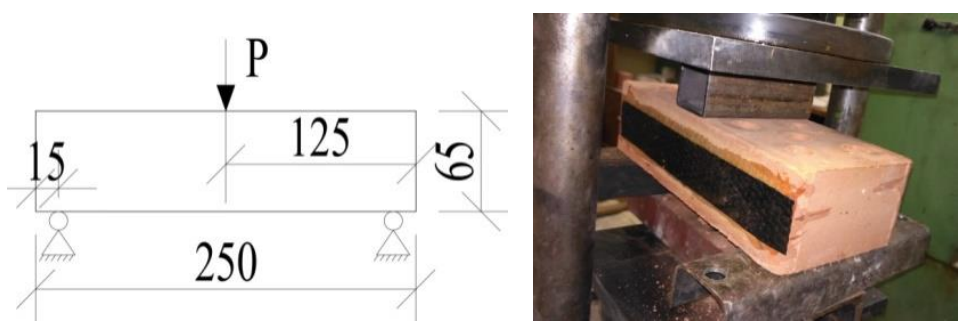

Fig. 8. Diagram and photo of applying load to tested bricks

Table 2

Results of the tests for tearing the plates off the bricks

\begin{tabular}{|c|c|c|c|}
\hline $\begin{array}{c}\text { No. of test } \\
\text { series }\end{array}$ & \multicolumn{2}{|c|}{ Average breaking force, } & \multirow{2}{*}{ Brick fracture pattern } \\
\cline { 2 - 3 } & $\mathbf{k g}$ & 100 & Broke in halves \\
\hline 1 & 70 & 685.7 & $\begin{array}{c}\text { Broken fragments were held in } \\
\text { place by the plates }\end{array}$ \\
\hline 2 & 480 & 728.5 & Same \\
\hline 3 & 510 & 607.1 & $-/ /-$ \\
\hline 4 & 425 & 978.5 & $-/ /-$ \\
\hline 5 & 685 & 842.8 & $-/ /-$ \\
\hline 6 & 590 & 407.1 & $-/ /-$ \\
\hline 7 & 285 & & \\
\hline
\end{tabular}

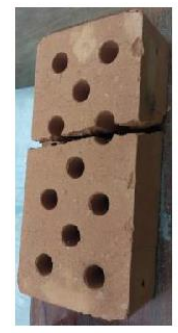

No. 1

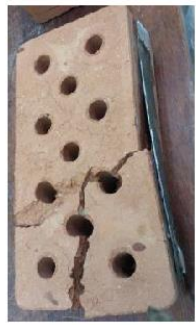

No. 2

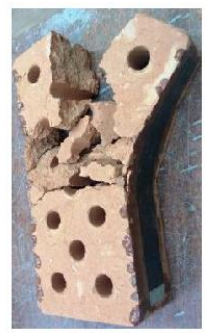

No. 3

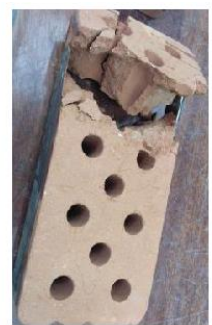

No. 4

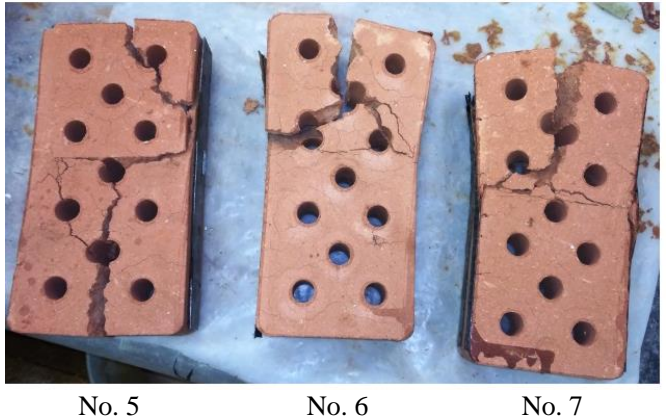

No. 5

No. 6

No. 7

Fig. 9. Brick fracture pattern upon undergoing strength tests 
Based on the experimental tests results (table 2) a histogram (fig. 10) of the average breaking force of the bricks strengthened with different methods was built.

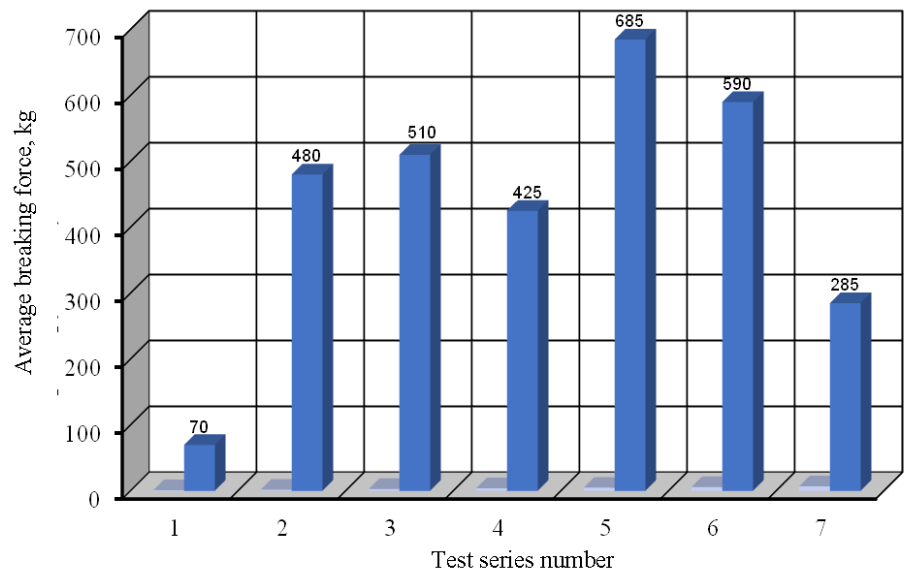

Fig. 10. Histogram of the average breaking force in different methods of brick strengthening

The analysis of experimental test results allows to claim that strengthened bricks can withstand significantly larger loads as compared to non-strengthened ones. It should be mentioned that the bending strength of a brick strengthened by two steel plate is $425 \mathrm{~kg}$, and the bending strength of a brick strengthened by the same method with additional fixing with anchors is $480 \mathrm{~kg}$. In addition, if bricks are strengthened with steel plates glued to the surface pre-coated with primer, its strength will increase up to $685 \mathrm{~kg}$, which is 9.7 times higher as compared with the strength of non-strengthened bricks.

\section{Experimental tests, Stage III}

At his stage, seminatural experimental tests of the technology of strengthening brick walls with external reinforcement were planned with the use of the results of the tests conducted at the previous stages.

For this purpose, three half-brick walls were prepared, made of M100 hollow ceramic bricks with M100 cement and sand grout. The height of the walls was $520 \mathrm{~mm}$, the length $-1,040 \mathrm{~mm}$.

The experimental tests plan provided for the following ways of walls strengthening:

- wall No.1 - non-strengthened (reference sample); 
- wall No. 2 - strengthened on both sides with steel plates fixed on EDMOK modified epoxy-based glue on the upper and lower parts of the wall. At the edges the plates are additionally fixed with anchors (fig. 11, a);

- wall No. 3 - strengthened on both sides with carbon unidirectional fibers fixed on EDMOK modified epoxy-based glue on the upper and lower parts of the wall (fig. 11, b)

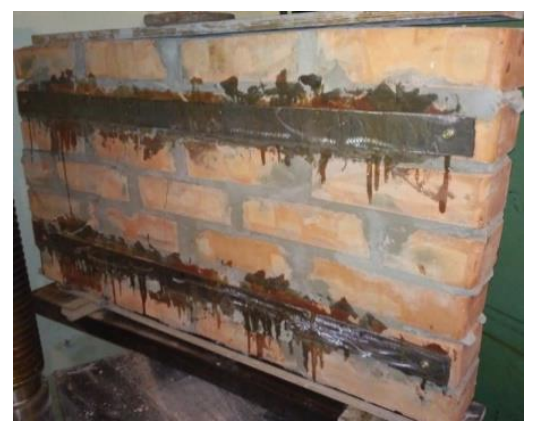

a

- wall No. 4 is wall No.1, which, after testing, was glued with EDMOK glue and strengthened with carbon unidirectional fibers fixed on EDMOK glue on the upper and lower parts. Before strengthening, the areas to which the fibers were glued on wall No. 4 were coated with Consolid 1 deeply penetrating epoxy-based primer (a total of 4 coats were applied).

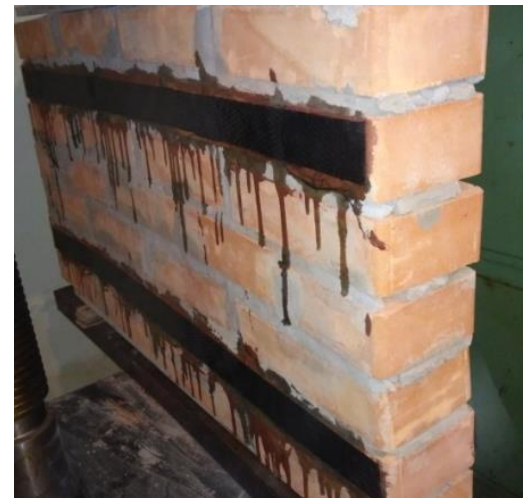

b

Fig. 11. Strengthened walls:

$\mathrm{a}$ - with steel plates; $\mathrm{b}$ - with carbon fibers 
Two days after the strengthening elements were glued to them, the walls were tested for bending strength with the help of PS-50 hydraulic press (fig. 12).

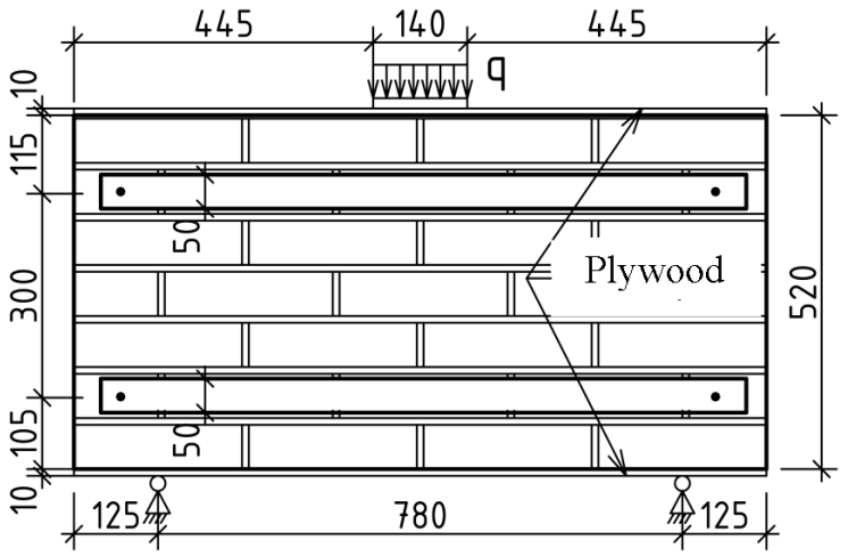

Fig. 12. Scheme of applying load to the walls

The experimental test results are displayed in table 3 and fig. 13.

Table 3

\section{Results of testing walls for bending strength}

\begin{tabular}{|c|c|c|l|}
\hline \multirow{2}{*}{$\begin{array}{c}\text { No. of the } \\
\text { wall }\end{array}$} & \multicolumn{2}{|c|}{ Breaking force, } & \multicolumn{1}{c|}{ Wall fracture pattern } \\
\cline { 2 - 3 } & $\mathbf{k g}$ & $\mathbf{\%}$ & \multicolumn{1}{c|}{ Broke in halves (fig. 13, a) } \\
\hline 1 & 1.890 & 100 & $\begin{array}{l}\text { The plates are intact. The plates with brick } \\
\text { fragments tore off the wall and the wall broke } \\
\text { (fig. 13, b) }\end{array}$ \\
\hline 2 & 8.650 & 457.6 & $\begin{array}{l}\text { The fiber is intact. From one side or the wall, at its } \\
\text { lower part, the ends of the fiber tore out fragments } \\
\text { of bricks and the wall cracked (fig. 13, c) }\end{array}$ \\
\hline 3 & 7.250 & 383.6 & $\begin{array}{l}\text { The fiber is intact. From one side or the wall, at its } \\
\text { lower part, the ends of the fiber tore out fragments } \\
\text { of bricks and the wall cracked (fig. 13, d) }\end{array}$ \\
\hline
\end{tabular}




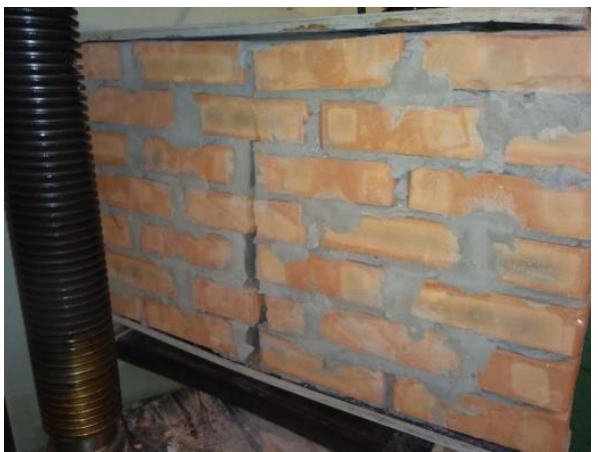

a

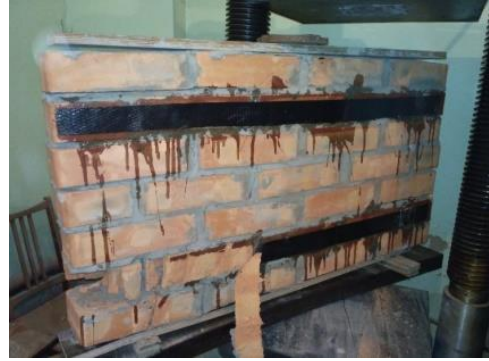

C

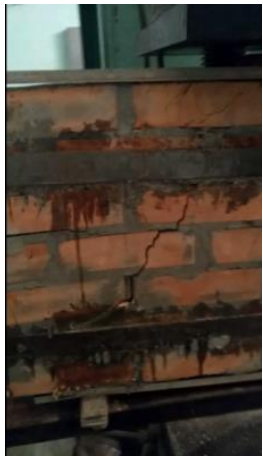

b

Fig. 13. Brick walls fracture pattern after they underwent strength tests

The analysis of experimental test results enables us to claim that strengthened brick walls can withstand significantly larger loads as compared to non-strengthened ones. It should be mentioned that brick wall strength depends on the strengthening type and base preparation. Bending strength of a wall strengthened by carbon fiber with pre-coating of the strengthening areas with primer is $11,500 \mathrm{~kg}$ and bending strength of a wall strengthened by the same methods without primer coating is $7,250 \mathrm{~kg}$, i.e., 1.5 times lower. 


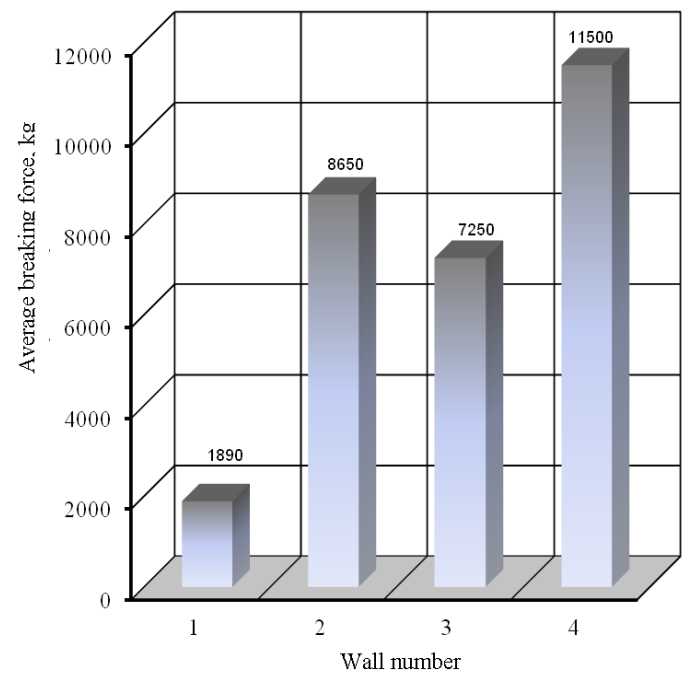

Fig. 14. Histogram of the breaking force in different methods of brick wall strengthening

\section{CONCLUSIONS}

The experimental tests conducted to identify the impact of the technological factor, i.e. the preparation of the brick base before gluing steel plates thereon, established that coating brick surface with Consolid-1 liquid primer increases the strength of adhesion of the plates to the bricks. Here, the strength of adhesion of the plates to the bricks raises with the increase of the amount of primer applied. Application of $9 \mathrm{~kg} / \mathrm{m}^{2}$ of primer allows to increase the adhesion of the plates to the bricks by $257.7 \%$.

The stage II experimental test results lead to the conclusion that strengthened bricks can withstand significantly larger loads as compared to non-strengthened ones. It should be mentioned that brick strength depends on the strengthening type. For example, bending strength of a brick strengthened by carbon fiber with pre-coating of the surface with primer is $728.5 \%$ higher than the one of a non-strengthened brick. In addition, if bricks are strengthened with steel plates glued to the surface pre-coated with primer, its strength will increase up to $978.5 \%$ as compared with the strength of non-strengthened bricks.

The analysis of stage III experimental test results enables us to claim that strengthened brick walls can withstand significantly larger loads as compared to non-strengthened ones. It should be mentioned that brick wall strength depends on the strengthening type and base preparation. Bending 
strength of a wall strengthened by carbon fiber with pre-coating of the strengthening areas with primer is $11,500 \mathrm{~kg}$ and bending strength of a wall strengthened by the same methods without primer coating is $7,250 \mathrm{~kg}$, i.e., 1.5 times lower. In total, such wall's bending strength is $608.4 \%$ higher as compared to a non-strengthened wall.

\section{SUMMARY}

From the analysis of technical inspection reports developed by the State Enterprise "V.S. Balitsky Research Institute of Building Production" it has been established that $85 \%$ of brick buildings over 30 years of age have cracks on their walls. The causes for brickwork fracture are: the increased load on these constructions due to the replacement or strengthening of upper constructions or replacement of technological equipment by items whose mass exceeds the mass of the ones used before the reconstruction, loss of bearing strength caused by operation: dynamic load, corrosive operational environment or atmosphere, improper operation, random damages, accidents. Current regulations and technical literature offer the following ways of strengthening or restoring the bearing strength of brick walls: full or partial replacement of the existing brickwork; injection of cracks; introduction of various strengthening elements; external reinforcement.

The technology of strengthening brick walls with external reinforcement using composite fibers, plates (lamellae) or grids glued onto the wall surface is widely used globally. However, virtually no domestic research is done in this area.

For this reason, the author conducted a number of experimental tests to develop and improve the technology of strengthening brick constructions with composite fibers glued to the wall surfaces.

The experimental tests conducted to identify the impact of the technological factor, i.e. the preparation of the brick base before gluing steel plates thereon, established that coating brick surface with Consolid-1 liquid primer increases the strength of adhesion of the plates to the bricks. Here, the strength of adhesion of the plates to the bricks raises with the increase of the amount of primer applied. Application of $9 \mathrm{~kg} / \mathrm{m}^{2}$ of primer allows to increase the adhesion of the plates to the bricks by $257.7 \%$.

The stage II experimental test results lead to the conclusion that strengthened bricks can withstand significantly larger loads as compared to non-strengthened ones. It should be mentioned that brick strength depends on the strengthening type. For example, bending strength of a brick strengthened by carbon fiber with pre-coating of the surface with primer is $728.5 \%$ higher than the one of a non-strengthened brick. In addition, if bricks are strengthened with steel plates glued to the surface pre-coated with primer, its strength will increase up to $978.5 \%$ as compared with the strength of non-strengthened bricks. 
The analysis of stage III experimental test results enables us to claim that strengthened brick walls can withstand significantly larger loads as compared to non-strengthened ones. It should be mentioned that brick wall strength depends on the strengthening type and base preparation. Bending strength of a wall strengthened by carbon fiber with pre-coating of the strengthening areas with primer is $11,500 \mathrm{~kg}$ and bending strength of a wall strengthened by the same methods without primer coating is $7,250 \mathrm{~kg}$, i.e., 1.5 times lower. In total, such wall's bending strength is $608.4 \%$ higher as compared to a non-strengthened wall.

\section{REFERENCES}

1. ДСТУ-Н Б В.1.2-18:2016 Настанова щодо обстеження будівель і споруд для визначення та оцінки їх технічного стану. - Київ: ДП «УкрНДНЦ», 2017. - 47 с.

2. ДСТУ Б В.3.1-2:2016 Ремонт і підсилення несучих i огороджувальних будівельних конструкцій та основ будівель i споруд. - Київ: ДП «УкрНДНЦ», 2017. - 72 с.

3. Савйовський В. В. Реконструкція будівель i споруд / В. В. Савйовський. - К.: Видавництво Ліра-К, 2018. - 320 с.

4. СТО 221 НОСТРОЙ 2.9.142-2015 Восстановление и повышение несущей способности кирпичных стен Проектирование и строительство. Правила, контроль выполнения и требования к результатам работ. - М.: «Издательство «БСТ», 2013. - 114 с.

5. Angelo Garofano. Structural behaviour of masonry walls strengthened with mortar layers reinforced with FRP grids. Master's Thesis. - Czech Republic, 2011. - 124 p.

6. Saman Babaeidarabad. Masonry walls strengthened with fabricreinforced cementitious matrix composite subjected to in-plane and out-ofplane load. Dissertation. - Coral Gables, Florida, 2013. - 147 p.

7. Костенко А. Н. Прочность и деформативность центрально и внецентренно-сжатых кирпичных и железобетонных колонн, усиленных угле- и стекловолокном. Автореферат диссертации на соискание ученой степени кандидата технических наук, Спец. 05.23.01. M., 2010. 29 c.

\section{Information about the author: Molodid O. S.,}

$\mathrm{Ph} . \mathrm{D}$. in Engineering, Associate Professor, Assistant Professor at the Construction Production Technology Department, Kyiv National University of Construction and Architecture 31, Povitroflotskyi Ave., Kyiv, 03037, Ukraine 


\section{APPLIED-SCIENCE BASES OF ORGANIZATIONAL-TECHNOLOGICAL AND ECONOMICAL-MANAGERIAL SUPPORT OF BIOSPHERE COMPATIBLE CONSTRUCTION PROJECTS}

\section{Chernyshev D.}

\section{INTRODUCTION}

The current state and the development trends of economy indicate the presence of important and complex problems caused by the housing stock obsolescence. Increasing problems related to high energy consumption of buildings and to deterioration of microclimate inside stimulate the scientists to look for measures that can effectively reduce energy consumption and solve environmental problems at different levels.

In the established practice of urban planning, the urbanized territories of cities have traditionally been considered as an object opposing to nature, and formation of urban society, virtually during the whole period of its existence, follows the path of extraction of natural resources despite the understanding of the limitations of the natural factor and its depletion. Therefore, the modern practice of urban planning, with insufficient account of the laws of interaction between society and nature, is accompanied by a significant negative anthropogenic impact on the natural environment, and this causes catastrophic consequences for the biosphere and the men, as its component part. An alternative to the established practice of urban planning and common modern ideology of urban territory as not more than a socioeconomic formation that is independent of the environment, can be in an eco-philosophical approach to the problem of relations between the human person and the nature. This approach is reflected in the new concept of innovative policy of urban planning and organization of real estate development on the basis of conceptual and environmental basis of biosphere compatibility - hierarchical system of knowledge, measures and decisions on preservation of human life support environment, maintenance of ecological equilibrium, reduction of negative influence of human activity on the environment, decrease or limitation of consumption of materials and energy sources.

Today, environmental problems are in level with economic problems and are of a general nature, and resolution of those requires the search for new instruments to address the challenge. One of the new instruments is in the 
concept of «green building», this is of great current interest in European countries and is being applied in Ukrainian realities as well.

The green building (Green Construction, Green Buildings) is the practice of construction and operation of buildings with purpose of decrease of the level of energy and material sources during the whole life cycle of the building: from selection of site and up to designing, construction, operation, repair and utilization. Another goal of a green building is to preserve or enhance the quality of the buildings and the comfort of their interior environment. This practice extends and complements the classical building design with the concepts of economy, quality, durability and comfort. New technologies are constantly being improved, and the green building is aimed at reducing the overall impact of the structures on the environment and human health, this is reached due to: - efficient use of energy, water and other resources; - attention to support of health of the residents and to improvement of productivity of the employees; - reduction of wastes, emissions and other impacts on the environment. The main tasks of the green building are: 1) reduction of the cumulative negative impact of construction activity on the environment and human health;2) reduction of the volume of wastes and decrease of other environmental impacts; 3 ) application of environmentally certified materials at construction and in decoration of the buildings; 4) improvement of energy efficiency of the building, minimization of energy consumption, use of alternative energy sources; 5) development of new technologies and creation of modern industrial products; 6) decrease of energy consumption and, accordingly, load on the electrical supply network; 7) integrated reduction of costs for construction and maintenance of buildings. The green building has become not exotic since about 20 years ago. Now, according to environmental standards, housing, shopping centers, officers, educational establishments and production workshops are being built according to ecological standards. Today, there are about 300,000 green constructions in the world. And this, to the fullest extent, gives the basis to consider green building as a global new tendency having long time ago gone out of the status of an experimental direction is rapidly spreading throughout the whole world.

\section{Coordination of the content of general methodological requirements \\ for construction of instruments for organizational and technological support of the projects of biosphere-compatible real estate development}

The concept of green building has originated in the 1970s as a response to the energy crisis and growing public concern about the deterioration of the environment. The need to save energy and to reduce the environmental load has promoted the emergence of green building innovations that continue to evolve till now. The main goal of the green building (green construction, 
ecological construction) is to minimize the negative impact on the environment from the construction industry at all stages by using the best technologies, improving quality and comfort. The main tasks include: 1) reduction of the level of consumption of energy and material resources throughout the whole life cycle of the building (site selection, design, construction, operation, repair, reconstruction, demolition, recycling, utilization); 2) minimization of air, water and soil pollution while optimizing the use of the natural resources; 3 ) improvement of quality and comfort of buildings; 4) application of innovative technologies. The construction industry is responsible for $25 \%$ of harmful emissions, $33 \%$ of greenhouse gases and $50 \%$ of landfill waste. The buildings use $14 \%$ of drinking water and $40 \%$ of energy and raw materials globally. While green building has great potential for the economical and environmental development of the industry, at the background of depletion of natural resources the need for substantial changes in the construction industry in accordance with current market requirements and leading world trends becomes particularly topical. Modern trends of building industry are evolving towards innovative green building technologies that minimize negative effect on the environmental, save natural resources and guard human health. Global trends indicate a quick increase in the number of green building projects in developing countries: Brazil -6 times, China -5 times, Saudi Arabia -4 times, and Mexico, Colombia, South Africa and India expect a twofold increase in green initiatives. Why should Ukrainians live less well? Implementation of green projects contributes to the energy and economic independence of Ukraine. The leading global investors favor green buildings, and innovations and increase of energy efficiency provide the Ukraine's economic development. But the most important thing is that green building has a positive effect on the social well-being of nation, improves the comfort, safety and health of the population. Is Ukraine ready for large-scale implementation of green building? Undoubtedly - yes! Green building is focused first of all on people. It is for those living and working in green buildings, designing and building the buildings, visiting the green buildings and using the infrastructure of the buildings. While the green building supporters are convincing the construction companies of its economic viability and energy efficiency, the ordinary citizens have no doubt about the benefits of green buildings. People spend more than $90 \%$ of their lives in buildings, with indoor pollution indicators being 2-5 times compared to the outside situation and, by the WHO estimates, $12.7 \%$ of deaths can be avoided if air quality in buildings is improved. Green standards carefully monitor the indoor air quality, the level of volatile organic compounds and other pollutants, with those of microbiological origin included. The Building Research Establishment, a British research center, provides dramatic 
statistics on the effect of low-quality housing on human health. The cost indicators for eliminating the negative effects of poor housing are ranked as fourth after such dangerous health risks as alcohol, smoking and obesity. The green building standards not only minimize the environmental impact at all the stages of the construction process, but are also focused on improving the health, safety and comfort of people. Green building safety standards include the reliability of building structures, inclusive and easily understood design of construction projects, operational risk management, safety of motion over the object, energy-efficient lighting of premises and surrounding areas. Living and working in green buildings is comfortable, since the green building standards include clear requirements for provision of ergonomics and convenience. The green building standards control the optimum mode of lighting, thermal comfort correlated with seasonal temperatures, ventilation and conditioning with regard to natural potential, acoustic comfort. Clear planning of green buildings provides convenient infrastructure, accessibility by transport and comfort of motion over the object. Special attention is paid to the attractive aesthetics of green buildings, because the constructed environment substantially affects the physical and mental state of people. In a green office it is better to work, and you want to stay longer, thus the level of performance is increased by $8-11 \%$ due to reduction of the illness frequency and to improvement of working conditions. In the areas with beautiful architecture, people feel satisfied, calm and happy, while ecologically friendly aesthetics and harmonious natural design create the conditions for inspiration and success. Application of green certification increases the financial characteristics for investors, lease takers and owners and encourages innovations in the construction sector. Dozens of green building certification systems are now in place, though the first were the British, who as long ago as in 1921 have established the scientific-research center for the real estate development, the Building Research Establishment (BRE), to take care of the development of the construction industry in in direction of decrease of negative impact on the environment. And just there in the 1990 the first system for certification by the green building standards has been developed - the Building Research Establishment Environmental Assessment Method (BREEAM) ${ }^{1}$. It is an independent and impartial method of environmental assessment of construction projects, infrastructure and buildings. It is currently used in 83 countries over the world and covers $80 \%$ of the registered green buildings in Europe. The BREEAM standards are scientifically based and are adapted to national building standards and local climatic conditions. BREEAM remains the world's first leading method for assessing the

\footnotetext{
${ }^{1}$ https://www.breeam.com/
} 
sustainability of general projects, infrastructure and buildings for a number of life-cycle stages: new construction, operation and reconstruction. In addition, the British green building system has a developed structure, so, the BRE Trust is a charity organization that supports the scientific and educational activities in directions of improvement of the built environment since 1997. Within this structure there functions the BRE Academy, a top ranked world leader in ecological building education for professionals on the basis of fundamental knowledge in the field of construction, architecture, urban planning, engineering and other areas of the construction industry. Despite the widespread use of BREEAM worldwide, there are currently only seven BREEAM licensed appraisers and the same number of registered green building projects in Ukraine, and only four buildings certified by the BREEAM standards. Large-scale implementation of green building requires the involvement of State structures. Previously, the green building has been associated with high costs, but the experience of developed countries shows that due to the State regulation a new market is emerging. More service providers appear, and at accumulation of critical mass this leads to lower prices. The State should formulate a goal, define a plan to achieve that goal and develop mechanisms to implement the plan. The government agencies should work closely with all the key participants of the construction sector to implement the green building practices, and then the green building in Ukraine will become not a luxury business but it will become a usual business model. Development of a sustainable urban environment is the result of the State policy and changes in public awareness. At presence of political will and a stimulating regulatory framework, green construction can go from underground in the mainstream.

Real estate development is an area of economic activity that has the greatest potential for energy saving, and as it is one of the main consumers of energy resources it has recently faced with the problem of the most rational use of those, at the stage of production of various building materials and of operation of completed real estate objects for different functional purposes as well.

In our opinion, the concept of green building is a combination of components of building ecology, namely the urban ecology, bio-positive construction, environmental reliability and safety, energy-active and energysaving buildings, resources, non-waste production, waste treatment and ecological monitoring.

According to statistics provided by the Ecological Building Council, the buildings around the world use today about $40 \%$ of all the primary energy consumed, $67 \%$ of all electricity, $40 \%$ of all the raw materials and $14 \%$ of all drinking water and generate $35 \%$ of all the carbon dioxide emissions and 
up to $50 \%$ of all solid wastes ${ }^{2}$. In this regard, the concept of «green» construction or, in other words, of ecological construction aimed at reducing the level of consumption of energy and material resources, as well as reducing the harmful effect of construction activity on human health and the environment has come to existence ${ }^{3}$.

Currently, the scientists are studying and providing several terms that are identical, namely, «green building», «ecological construction», «sustainable construction», «eco-development». However, in recent years, the term «green building» has become more widespread. The wording «green building» originated in the the United States and European countries as early as the 1970s. The cheapness and inexhaustibility of energy reserves led to a rather wasteful nature of use of those, this has most clearly manifested itself in construction, as the result during fifteen years (from 1965 to 1980) the world energy consumption has become, on average, 1.7 times higher, and the energy consumption for construction and operation of buildings and structures (excluding consumption for production) in the 1970s began to account for about half of the total energy consumption in the most of developed countries: in Germany, in Netherlands - 39\%, Ireland - 46\%, the United Kingdom - $48 \%$, Denmark - $50 \%$. In addition, more than $90 \%$ of those volumes, according to the EEC (European Economic Commission) data, are directly related to operation of buildings and structures ${ }^{4}$. The gradual but steady depletion of the explored fields of traditional energy sources have made need in the development of new ones, mainly located in regions with hard climate, and this has lead to increase in the specific cost of fuel production by more than 3 times. Due to those circumstances, the significant rise in world prices for traditional energy carriers, which occurred in the late 1970s, called into question the feasibility of construction in general: the cost of maintaining buildings has began to exceed the revenues from use of those. In 1975, the first demonstration buildings with high energy efficiency appeared. So, it can be asserted that the green building has emerged not long ago, but it is growing rapidly and becoming more and more popular all over the world. As a result there are new technologies; and the industrial activities of people have led to environmental degradation. Increasing levels of pollution of environment all over the world, global warming and the necessity of more economical use of the planet's energy resources have become the major factors for development of green building.

\footnotetext{
${ }^{2}$ Офіційний сайт компанії Life House Building. - Режим доступу: http://lhb.com.ua/

${ }^{3}$ Офіційний сайт компанії Еcopan. - Режим доступу: https://ecopanua.com/

${ }^{4}$ Orlovs'ka Y. Green investments' programs as an element of industry's international mpetitiveness (on example of construction industry) / Y. Orlovs'ka, O. Kvaktun, V. Chala, M. Vovk // Marketing and Management of Innovations. - 2017. - № 3. C. 366 - 377.
} 
Green building is also understood as construction and operation of buildings with lower consumption of energy and materials throughout the whole life cycle of a building. In our opinion, the most appropriate is the definition given by the National Agency for Sustainable Development, according to which the green building is a practice of construction and operation of buildings, the purpose of which is to decrease the level of consumption of energy and material resources throughout the whole life cycle of the building, to support or improve the quality of buildings and the comfort their indoor environment. The major concern of this approach is to reduce the overall impact of the building on the environment and human health. This practice extends and complements the classical construction design with the concepts of economy, utility, durability and comfort. From this definition, we consider it necessary to point out the main tasks of green building. So, in our opinion, the main tasks of green building are:

- to increase the efficiency of use of natural and renewable resources (sun, wind, water);

- to decrease emission to atmosphere of gases with formation of the greenhouse effect;

-to increase the share of renewable energy sources (sun, wind, water) through their introduction into technological process and use in the operation and maintenance of residential green buildings;

- to reduce the negative effect (over the whole life cycle of a building) on human health while staying in a dwelling house through application of the latest, energy sawing, natural and safe materials;

- to reduce the loads on power networks through introduction and application of renewable energy sources;

- to reduce the operating expenditures.

Having pointed out the green building goals, the authors consider it to be appropriate to focus on the benefits and purposes of implementation of green building pursued by different businesses entities. For example, the benefit of architects is first of all in increasing their competence and high appraisal of design projects, and therefore increase of the salaries; as to contractors and developer companies, the benefit of introduction and building green homes is in increase in orders for construction objects and rather quick sale of apartments in green buildings. The benefits of manufacturers of building materials are in increasing profits, increasing competitiveness at the national market of building materials and entering new markets. The State also benefits from introduction of green building, this is in meeting the environmental investment commitments (Kyoto Protocol), reduction of unemployment level and creation of new jobs. For developers, their benefits include attracting additional investments in the country and the industry. The landlords' benefits are to increase the rental rates and the level of occupancy 
after the house is put into operation. The benefit of the population from green building is in reduction.

\section{Formation of methodical-analytical system of indicators for provision of biosphere compatibility at preparation and organization of construction}

The green construction is realized as «Green Buildings». A green building, or an environmentally sustainable building, is the result of a design philosophy that seeks to: increase the efficiency of use of scanty resources (land, energy, heat and cold, water and materials); to reduce the adverse impact on human health and to minimize the negative effect on the environment throughout the whole life cycle of the building, through better location, design, construction, management, operation and further demolition ${ }^{1}$. It should be noted that the «green building», «green buildings» is a practice of constructing and operating buildings with the purpose, first of all, to reduce the consumption of energy and material resources throughout the whole life cycle of the building: from the site selection and further at designing, during construction, operation, repair and demolition. Another important goal of green building is to maintain or enhance the quality of buildings and the comfort of their indoor environment. These statements, in our opinion, substantially complement the standard, conventional real estate development with concepts like economy, durability and comfort.

Though the new green building construction technologies are constantly being changed and improved, the main goals of green buildings are:

- reduction the overall impact of the building on the environment and human health that can be achieved through the efficient use of electric energy, water and other resources;

- reduction of wastes, emissions and other impacts on the environment. In addition, green buildings are completely cost-effective and do not require high maintenance costs, this saves money ${ }^{2}$.

The definition of «green building» covers all the phases of the life cycle of a building, including design, construction, operation and demolition (dismantling). The green buildings save resources by using energy, water and materials more efficiently throughout their life cycle that also includes the initial phase of construction. Most scientists compare the environmental stresses generated throughout the whole life cycle by constructing bimetallic and hollow flooring systems for commercial buildings with application of mixed life cycle assessment method. The studies cover the stages of material extraction and construction and include the detailed assessment of the direct effect and the effect of material supply chain as well. A number of results are obtained, those are presented in several categories for comparative evaluation. Those include the energy consumption, emission of carbon 
dioxide $\left(\mathrm{CO}_{2}\right)$, carbon monoxide $(\mathrm{CO})$, nitrogen dioxide $\left(\mathrm{NO}_{2}\right)$, sulfur dioxide $\left(\mathrm{SO}_{2}\right)$, fine particulate airborne matter $\left(\mathrm{PM}_{10}\right)$ and volatile organic matter. The other categories include solid wastes and release of liquids.

Hereinafter, the author considers it necessary to analyze separately the main types of green building. There are nine types of nesting architectural and planning solutions in the concept of green housing development:

- The energy-efficient building with low or zero energy consumption (zero-energy building). This is, first of all, a building with high energy efficiency that can produce power through renewable energy sources. If the building produces less energy than it is needed for consumption, the building is called a near zero-energy building. The advantage of zero energy buildings is that they do not use fossil fuels and get all the energy they need through introduction of renewable energy sources.

- A passive building is a building that uses energy-saving building materials and renewable energy sources. It can also be said that it is an ecohouse with heat generated by passive method, with application of available internal heat sources only, for instance solar energy that goes through the windows. The main advantage of a passive house is that there continually circulates clean and warm fresh air, and the walls and floor are also warm all the time.

1. Bioclimatic architecture is a building with pronounced use of glazed spaces and with natural light. Bioclimatic architecture is a building constructed with account of the climate of the region that has to provide required comfortable living conditions with minimal energy consumption and with use of environmentally friendly sources of energy like sun, wind, water promoting saving of energy for heating, cooling and lighting the building.

2. An intelligent or smart building is a building where the flows of light and heat in premises and structures are optimized. An intelligent, or a smart building (smart home, digital house) is a residential house or premises of building for commercial purposes with high-quality support systems and an operational multi-room. Multi-room is a system by means of which all the electrical devices of the building can be functionally interconnected, with possibility of centralized control from a remote display.

3. A high-tech building is a building with state-of-the-art solutions in architecture in terms of constructions and materials.

4. A healthy building that prioritizes ecologically friendly natural building materials.

5. A life-support building with zero waste characteristic and zero characteristic of energy consumption.

6. Eco-low-tech is a building that is built with use of local natural materials like wood, clay, straw and so forth. 
7. Eco-futurism. A completely new trend in the construction of buildings, the main idea of which is that the new artificial substances will be non-toxic and will become integral parts of waste-free economic cycles. Part of the elements of the house after the onset of its physical deterioration and moral depreciation will return to the soil and dissolve in it, and the other part can be re-incorporated into new production chains.

Thus, having analyzed the types of green housing construction, we can conclude that the construction of green buildings in the sector of housing development is aimed at improving the energy efficiency, improving living conditions through introduction of ecologically friendly materials to the technological process of construction. That is, the construction of green buildings is first of all aimed at meeting the needs of society.

Therefore, the main economic advantages at the implementation of green building and green technologies are the reduction of the prime cost of construction, increase of consumer demand for green houses by $35 \%$ compared to conventional ones. Besides that, application of green construction leads to reduction in operating costs by $13.6 \%$ compared to conventional buildings. Economic effects:

- Increased current net income (for example, a $3 \%$ premium by average rate of lease agreement) and property asset value (for instance, $10 \%$ premium for commercial value) may result in lower financial and insurance costs;

- Most «green buildings» are more expensive than conventional ones by no more than $4 \%$, and in the near future the use of green technologies will become the most effective means of reducing the prime cost of construction;

- Green construction leads to increase in consumer demand for green buildings (by $35 \%$ ) and the market demand (by $33 \%$ );

- Reduction of operating costs by $13.6 \%$ for new construction and by $8.5 \%$ for an existing building;

- More than $50 \%$ of hot water needed for the household purposes that is heated by solar collectors, with the excess re-directed to the heating system. The required volume of drinking water is decreased by $26,000 \mathrm{~m}^{3}$ per year;

- Recycling and reuse of $98 \%$ of the waste left over at reconstruction of the old building. More than 30 tons of such unnecessary materials are used as building elements for $15,000 \mathrm{~m}^{2}$ of other buildings.

When constructing a green building, it is possible to use the wastes from reconstruction of the old building, this leads to savings on building materials.

Among the environmental benefits it should be noted that at construction of a green building made of wood, it is possible to reduce the $\mathrm{CO}_{2}$ emission by 0.8 tonnes. 
The social benefits should also be addressed, with emphasizing the following ones: in a green building rate of work is much higher compared to a conventional building, and it is possible to reduce the cost of purchasing medicines through construction of green houses.

It should be noted that as green buildings there can be not only newly built buildings. Virtually any building can be upgraded, with implementation of environmentally friendly technologies that optimize energy consumption and reduce the negative environmental impact.

When designing a green building project, the environmental impact of the building is also taken into account: how harmoniously it fits the natural landscape, thus making an attempt to minimize the environmental impact of the construction process. Today, the share of green buildings in the total number of new buildings in the EU countries has reached 20, and the number of such buildings in developed countries is constantly increasing. As for Ukraine, according to experts, the country now has all the preconditions and conditions for the development of green building.

The concept of green building views the real estate object not only as a construction product, i.e. as completed in construction and put into operation buildings and structures, but as a place for existence of a human person, i.e. the whole set of factors of the building and its infrastructure that determine the living conditions. At that, most scientific and methodological and regulatory sources define the green building as an approach to the design, construction and operation of buildings, a number of solutions, measures, with cover the materials and equipment aimed at energy efficiency and resource efficiency, safety for human health, comfort and environmental friendliness. The main requirements for such objects throughout the whole life cycle are the rational use of renewable resources (energy of the earth, water, wind, etc.), minimization of the negative impact on the natural environment, comfortable living conditions for people. We detail each of the highlighted groups of problems.

Environmental problems: depletion of natural resource potential of territories; pollution of environment (lithosphere, atmosphere, hydrosphere, etc.); increase of man-caused load on the environment as the result of intensification of production; finiteness of non-renewable natural resources; depletion of resources; inability to predict externalities; global climate change; impossibility of assimilation processes; reduction of biodiversity; the process of degradation of environmental components that has no retroactive effect; accumulation of significant amounts of industrial and solid household wastes; the emergence of ozone holes (greenhouse effect, global warming) and the like.

Economic problems: lack of adequate financing of environmental measures by economic entities, although this is the largest share of sources 
of financing the environmental measures; not enough use of innovative potential of enterprises; absence of widespread system of environmental management at enterprises; moral and physical deterioration of fixed assets; large amount of industrial wastes; lack of motivation for environmental activities; poor product quality; absence of a well-established system for processing production wastes; extremely poor level of development of own production; rather narrow focusing in specialization of regions on the production of industrial, consumer and agricultural products, etc.

Political problems: unstable political situation in the country that has a negative impact on all spheres of life; the lack of a clear environmental policy of the State; absence of a political lobby for proper financing of problematic subformations, since $91 \%$ are financed from own funds, and only the rest ones - from the State and local budgets.

Technological problems: excessive scale of production potential of the fuel and energy complex and heavy industry; a significant lag behind the world level of technical indicators and resources used in the national economy; differentiation of economic entities by the technical level of the production fund, the conditions for providing resources and sales of products; gaps in the technical level, in the quality of machines, equipment and other resources involved in integrated chains of production and technological links.

Market problems: lack of market of green products; distribution of products dangerous for the health of population; absence of market mechanisms for regulation of environmentally safe and cost-effective economic activity; low level of competitiveness of domestic enterprises; insufficient level of solvent demand for ecologically safe products.

Socio-demographic problems: deterioration of the quality of life of population, deterioration of health, low level of income of citizens, emergence of incurable diseases and spread of those, propagation of genetically modified food products, lack of a system of formation of environmental responsibility and environmental education; change of cultural values, moral and ethical degradation of society, rapid pace of urbanization, untimely and incomplete informing of population on the whole range of problems that are to be solved on the way to sustainable development of society, problems of activating public activity, etc.

Institutional issues: lack of regulatory support for sustainable development at both, the national and the regional levels; the imperfection of the current state of legislation on the transition to sustainable development and the practice of law enforcement in the field of nature management and protection of environment; insufficient motivation of environmental protection activities by the State and the regional governments; lack of a strategy for transition to sustainable development; absence of an adequate 
number of relevant institutions to address the above issues; a poor role of environmentally-oriented organizations in public life.

In the process of development of the organizational concept of construction process, the main task is to build an organizational and technological model that takes into account the structure of construction flows and the algorithms of functioning and interaction of those. Both tasks are initially formed on the basis of the design estimation documentation.

However, usually, when designing the organization of operation of complex construction systems, it is not possible to find a clear unambiguous solution. There are always several alternative solutions to form up the system of building and installation works (BIW) and special works, at that each of those solutions provides the ability of substantial modifications, and in the process of construction at can be radically changed, adjusted in an operational manner.

The cost and duration of the works depend on the method of organization of construction, technology of performance of BIW, and the choice of those is influenced by the adopted architectural and planning, constructional and engineering solutions.

Referring to ${ }^{5}$, the determination of the duration of construction depends on the available initial data, namely:

- the volume of construction work, expenses for labor, material and technical resources required to perform construction work;

- the master plan solution;

- three-dimensional design and structural solutions for the project ;

- general organizational and technological schedules for construction of the basic building object and the facilities for utility and service purposes, energy economy, transport and communication, external networks;

- the list, the volumes and duration of works carried out during the preparatory period;

- the construction conditions (building density, engineering and geological conditions, etc.);

- conditions for financing the construction;

- information on the terms of delivery and transportation from enterprises - suppliers of building structures of finished products, materials and equipment (possible terms, frequency, volumes and completeness of delivery, etc.);

- information on provision of the construction site with labor resources (qualitative and quantitative composition, average productivity of workers

\footnotetext{
${ }^{5}$ Визначення тривалості будівництва об'єктів: ДСТУ Б А.3.1-22:2013 / Мінрегіонбуд України. - Вид. офіц. - Чинний від 2014-01-01. - Київ, 2014. - 30 с. - (Національний стандарт України)
} 
by type of work), construction machines and mechanisms (list, number, productivity), etc.

It should be noted that the estimated cost of construction has to take into account the change in the value of money over time, so in the cost characteristics of the project, at the design stage, application of the hereinafter contained is to be foreseen: the inflation index, determined by the State Statistics Committee of Ukraine; the index of change in the cost of construction and installation works determined by the Ministry of Regional Development of Ukraine; as well as the coefficient taking into account the regional construction conditions determined by the Ministry of Regional Development of Ukraine ${ }^{6}$.

Nowadays, the characteristics of cost and duration of construction determined at the planning stage substantially differ from the real ones, in particular the research ${ }^{7}$ provides up-to-date data on construction of a number of objects from which it follows that the larger the area and, respectively, the longer in time the term of construction is, larger is the the actual deviation of the real terms of construction from the planned ones, for various reasons, in some cases by $50 \ldots 100 \%$, being a problem for ensuring the reliable implementation of construction projects by construction organizations.

At determining the factors that have a determinative influence on the performance characteristics of organizational and technological construction solutions, V.I. Bolshchakov, T.S. Kravchunovska, S.P. Bronevitsky have identified the main factors affecting the increase in the cost of construction ${ }^{8}$ :

- the low level of organization of the construction process, logistics and calculations in the construction, this causes losses because of defects and idle time in amount of up to $12-15 \%$ of the construction cost;

- the design shortcomings, poor quality of design estimation documentation;

- high expenses for the engineering preparation of the territories, imperfection of the rules for determining the costs for connection to the engineering networks and main sources of water, electric power, gas;

${ }^{6}$ Организационно-технологическая и экономическая надежность в строительстве / В. Р. Млодецкий, Р. Б. Тян, В. В. Попова, А. А. Мартыш. - Днепропетровск : Наука и образование, 2013. - 193 с.

7 Большаков В. І. Фактори, що здійснюють визначальний вплив на показники ефективності організаційно-технологічних рішень будівництва доступного житла [Електронний ресурс] / В. І. Большаков, Т. С. Кравчуновська, С. П. Броневицький // Вісник Придніпровської державної академії будівництва та архітектури. - 2016. - № 5. C. 61-70. - Режим доступу: http://nbuv.gov.ua/UJRN/Vpabia_2016_5_10

8 Большаков В. I. Фактори, що здійснюють визначальний вплив на показники ефективності організаційно-технологічних рішень будівництва доступного житла [Електронний ресурс] / В. І. Большаков, Т. С. Кравчуновська, С. П. Броневицький // Вісник Придніпровської державної академії будівництва та архітектури. - 2016. - № 5. C. 61-70. - Режим доступу: http://nbuv.gov.ua/UJRN/Vpabia_2016_5_10 
- growth of cost of building materials, products and structures;

- frequent change of contractors, imperfection of competition procedures for selection of the contractors;

- frequent shutdowns of the production cycle and conservation of facilities due to lack of financing (construction renewal costs result in losses of up to $10 \%$ of the estimated cost).

To the factors that will definitely affect the cost and duration of construction, the scientists ${ }^{9}$ attribute the architectural and planning decisions, structural systems of buildings, material of supporting structures, the level of engineering support of the building, the energy efficiency class of the building.

The degree of influence of the factors on the cost and duration of construction is given in Table. 1 .

Table 1

The main characteristics of evaluation and identification

of organizational and technological reliability in the projects

of biosphere compatible construction

\begin{tabular}{|c|c|c|c|}
\hline \multirow[b]{2}{*}{ No. } & \multirow[b]{2}{*}{ Factor } & \multicolumn{2}{|c|}{ Degree of effect on * } \\
\hline & & $\begin{array}{c}\text { Cost of } \\
\text { construction }\end{array}$ & $\begin{array}{l}\text { Duration of } \\
\text { construction }\end{array}$ \\
\hline 1. & $\begin{array}{l}\text { Urban features and investment } \\
\text { attractiveness of urban areas }\end{array}$ & 3 & 1 \\
\hline 2. & $\begin{array}{l}\text { Storey number (multifunctionality) of the } \\
\text { building }\end{array}$ & 3 & 3 \\
\hline 3. & Total area of the building & 3 & 3 \\
\hline 4. & Construction volume of the building & 3 & 3 \\
\hline 5. & Methods of organization of construction & 3 & 3 \\
\hline 6. & Confinement of the construction site & 3 & 3 \\
\hline 7. & $\begin{array}{l}\text { Reliability of organizational and technological } \\
\text { solutions }\end{array}$ & 3 & 2 \\
\hline 8. & Commonality of structures & 2 & 3 \\
\hline 9. & The degree of prefabrication of buildings & 2 & 3 \\
\hline 10. & $\begin{array}{l}\text { Availability of storage and structure assemblage } \\
\text { areas }\end{array}$ & 1 & 1 \\
\hline 11. & Adaptability of design solutions & 3 & 3 \\
\hline 12. & Durability of the building & 1 & 1 \\
\hline 13. & Productivity of work & 1 & 2 \\
\hline 14. & Methods for staff motivation & 1 & 1 \\
\hline
\end{tabular}

*1-Low level of effect, 2 - moderate, 3 - high level.

${ }^{9}$ Стан реалізації ключових завдань Державного агентства 3 енергоефективності та енергозбереження України у 2015 році [Електронний ресурс]. - Режим доступу: http://saee.gov.ua/sites/default/files/Presentation_2015.pdf 
Despite the obvious benefits, the development of green building in Ukraine is quite problematic. The green building market is represented by single private companies. The best known among those are: LifeHouseBuilding (500 projects are developed, more than 50 structures are built in Dnipro, Kyiv, Kharkiv, Lviv, Vinnytsia region, Kamiansk, Zaporizhia and Crimea ${ }^{2}$ ), Ecopan (more than 500 projects are implemented in Ukraine and Europe $^{3}$ ). The scale of construction within the State is negligible. The main reason for this is in high initial expenses and the unpredictable commercial benefits of such investments. The cost of ecological construction exceeds the cost of traditional real estate development by $30 \%$. In addition, corruption and unorganized information activities on scientific and technical proposals hinders the development of the sector at the internal level ${ }^{9}$. This problem can be addressed through appropriate State policy. However, no tools have been developed till now to encourage the new green construction. The main normative legal acts related to this field are: the Law of Ukraine «On Energy Efficiency of Buildings» dated July $1,2019^{10}$, the Law of Ukraine «On Amendments to Some Laws of Ukraine on Ensuring Competitive Conditions for Production of Electricity from Alternative Energy Sources» dated May 25, 2019, No. 2712-VIII ${ }^{11}$, the Law of Ukraine «On the Environmental Impact Assessment» dated May 23, $2017^{12}$. Though there is no systematic vision of the State as to promoting ecological construction. The situation is somewhat better with regard to the ecological modernization of energy-intensive multi-storey buildings. Since October 2014, the Government «Warm Credit» Program has been in operation; in 2015, 80,000 loans were provided, in amount of UAH 1.3 billion, and of those, UAH 302 million is reimbursed ${ }^{9}$. However, this instrument is mainly for the household sector, without affecting the large scale of construction activity. The State agencies are just beginning their activities in the field of «green building». The State Agency for Energy Efficiency and Energy Saving of Ukraine, in cooperation with European partners, has implemented four projects of «green building» on thermal modernization of equipment ${ }^{13}$. On May 30, 2017, the Committee on Green

\footnotetext{
${ }^{10}$ Про енергетичну ефективність будівель: Закон України від 1 липня 2019 року № 33 [Електронний ресурс]. - Режим доступу: https://zakon.rada.gov.ua/laws/show/2118-19

${ }^{11}$ Про внесення змін до деяких законів України щодо забезпечення конкурентних умов виробництва електричної енергії з альтернативних джерел енергії: Закон України від 25 травня 2019 року № 2712-VIII [Електронний ресурс]. - Режим доступу: https://zakon.rada.gov.ua/laws/show/2712-viii

12 Про оцінку впливу на довкілля: Закон України від 23 травня 2017 року № 29 [Електронний ресурс]. - Режим доступу: https: https://zakon.rada.gov.ua/laws/show/2059-19

13 Реалізовані проекти Державного агентства 3 енергоефективності та енергозбереження України [Електронний ресурс]. - Режим доступу: http://saee.gov.ua/ uk/business/realizovaniproekty
} 
Ecological Construction was established at the Construction Chamber of Ukraine. However, on the official website of the institution ${ }^{14}$ there is no information regarding the committee's powers. Thus, the "green building» in Ukraine is at an early stage of development, and its prospects will depend on the effectiveness of the State support for the sector. The State institutions face the key challenges, those are are in elaboration of strategic documents on green building development and provision of State support instruments (benefits for companies operating in this field and attraction of international assistance), in conducting an information campaign on promoting the benefits of green building in Ukraine, preparing and implementing a system of standards in the field of ecological construction.

The main tool for implementing the principles of green building in real estate projects is the so-called green certification system. The «Green certification» systems are characterized by the following: - assessment of the entire life cycle of a building, not just the design and construction part; application of a wide range of different criteria evaluating the location of the site, the design and construction technologies applied, the use of the renewable energy sources, dismantling technology, etc.; - certification is not a single action, but it is a process that accompanies the design and construction of the object. There are several independent certification systems in green building. Most widespread: - BREEAM (Building Research Establishment's Environmental Assessment Method, UK), since 1990 about 558,000 buildings in 50 countries have been certified. The previous LEED certification was obtained by the Astarta Business Center in Kyiv and the Optima in Lviv; - LEED (Leadership in Energy and Environmental Design, USA), since 2000, has certified about 90,000 buildings. In Ukraine, under this system the US Embassy building and Shell office (in Toronto Business Center) are certified; - DGNB (Deutsche Gesellschaft für Nachhaltiges Bauen, Germany), since 2009, approximately 1100 buildings have been certified. As a 2nd generation rating system, it provides the most comprehensive assessment of a building from the point of view of «sustainable development». The State does not yet have programs for support of this direction that would meet the global trends of the regulatory framework. However, there is a positive experience in supporting at the State level of the direction of renewable power generation, this has led to substantial progress in this area («green» tariff law).

In 2013, the public organization «Green Building Council» (UaGBC) was registered in Ukraine, with the main objective of bringing together organizations and professionals who adhere in their activity to the principles

\footnotetext{
14 Повноваження Комітетів Будівельної палати України [Електронний ресурс]. Режим доступу: http://budpalata.com.ua/category/povnovagenya-komitets
} 
of green building. The main priorities of the Council are: - to amend the Ukrainian legislation, for development of green direction in the industry of real estate development; - certification of buildings in accordance with «green» standards; - dissemination and promotion of the «green» building ideas; - introduction of international standards of green building in Ukraine. The Council brings together the companies, organizations and individuals interested in application of the principles of sustainable development when implementing the real estate projects, projects of the energy generating industry and of related fields. Ukraine has become a member of the World Green Building Council since 2016. Now, the main tasks for the country are: - to develop a regional network of offices; - to establish a system of design, construction and evaluation according to the criteria of green building. However, the development of green building in Ukraine is possible only under the following conditions:

1. Upgrading of the level of qualification of specialists.

2. Introduction of the "Green Building» course into the educational process.

3. Design, construction and operation by the green building standards.

4. Development of scientific support for this standard.

5. Development of production and operation of environmentally friendly equipment and materials.

6. Introduction of taxes on building materials, except of environmentally friendly.

7. Increase of the demand for green buildings.

8. Increase of environmental awareness of population.

9. Development of State building codes for the design, construction and operation of green buildings.

10. Design of buildings with low level of energy consumption.

From the point of view of biosphere compatibility, construction development must ensure the integrity of biological and physical natural systems. Of particular importance is the viability of the ecosystems on which the global stability of the entire biosphere depends. Moreover, the concept of «natural» systems and habitats can be understood broadly, with the created by human person environments, like the urban one, included. The focus is on maintaining the self-regeneration ability and capacity of such systems to dynamically adapt to changes, rather than keeping those in some «perfect» static state. Degradation of natural resources, pollution of environment and loss of biological diversity reduce the ability of ecological systems to recover. Construction is one of the powerful anthropogenic factors for environmental impact. The anthropogenic effect of construction is diverse in its nature and takes place at all the stages of the construction activity - from 
the extraction and production of building materials, construction of objects, operation of those and with the end at dismantling of worn buildings. It is proposed to base the development of a methodology for assessing the biosphere compatibility of architectural objects on the ideas laid out to calculate the indicator of the level of implementation of the functions of biosphere compatible settlement. The architectural object biosphere compatibility index $\mathrm{Zbs}$ is proposed to be calculated by the formula:

$$
\mathrm{Zbs}=\Sigma\left(Z i * m_{i}\right)=Z \mathrm{M}^{*} \boldsymbol{m} \mathrm{M}+Z \mathrm{~b}^{*} \boldsymbol{m} \mathrm{5},+Z Ж m Ж+Z Д * m Д
$$

where

ZM - the index of biosphere compatibility for plant-manufactured materials and products of which the building is constructed;

Z6 - the index of biosphere compatibility for the phase of construction of the building;

$Z$ Z - the index of biosphere compatibility for the stage of the life cycle (operation) of the building;

$\boldsymbol{Z}$ Д - the index of biosphere compatibility for the phase of demolition and utilization of the materials and structures of which the building was constructed;

$\mathbf{m}_{\mathbf{i}}=\{\boldsymbol{m} \mathbf{M} ; \boldsymbol{m} \mathbf{5} ; \boldsymbol{m}$ Д $\}-$ the weight coefficients of the respective indices.

The accuracy of the complex evaluation is enhanced when the weight coefficients of the of the property indices are taken into account. At account of the weighting factors, the question of determination of those arises. There are computational methods for determining those coefficients, though the methods are imperfect and often enough produce inconsistent results. At the present stage, it is better to use an expert method for determining the weight factors that is based on the application of generalized experience and intuition of expert specialists. Among the expert methods, the most suitable for determining the weighting factors are: preference method, rank method, pairwise comparison method, etc. The most common method is the method of preference, it is realized as follows: the experts assign the numbers to the weights of all the characteristics in order of preferences of those, so that the most important one is given the weight of number 1, the next one by importance - number 2, and so on. Then the arithmetic mean value is calculated by each characteristic, with account of the opinions of all experts. With the ranking method, the experts evaluate the importance of each characteristic on the grounds of a predefined scale of relative importance in 
the range from 0 to 1 . The weighting factors $m i$ are found on the basis on the estimates assigned by all the experts for each characteristics in their totality, with application of ranks. According to International Standards (EN 1990:2001 / Eurocode - Basis of structural design), the reliability of construction objects - in a single cycle «preparation-constructionoperation» - is considered as a combination of safety, suitability for normal operation and durability. Safety is considered as an attribute of a construction object to maintain its suitability for operation during a prescribed period without potential threat to human life and health.

In the established practice of urban planning, the urbanized territories of cities have traditionally been considered as an object opposing to nature, and the formation of urbanized society, practically for the whole period of its existence, folows the way of extraction of natural resources despite the understanding of the limitations of the natural factor and its depletion. Therefore, the modern practice of urban planning, with insufficient account of the laws of interaction between the society and the nature, is accompanied by a significant negative anthropogenic effect on the natural environment, this causes catastrophic consequences for the biosphere and the human being as a part of it. As an alternative to the established practice of urban planning and the deep-rooted modern outlook on the city as a socio-economic formation only, independent of the natural environment, there can be the eco-philosophical approach to the problem of relations between the humans and the nature. This approach is reflected in the new concept of innovative policy of urban planning and organization of construction activity on the basis of conceptual and environmental basis of biosphere compatibility hierarchic system of knowledge, measures and decisions on preservation of the life support environment, maintenance of ecological equilibrium, reduction of negative impact of human activity on the natural environment, decrease or limitation of the volumes of consumption of materials and energy sources.

\section{CONCLUSIONS}

In the EU countries, the innovative construction programs and projects of development of urban areas based on the so-called «biosphere compatibility» are gradually being developed. The key strategic determinants of those programs and projects are: 
- organization of construction on fundamentally innovative principles that in the priority are aimed at formation of safe (and favorable for selfdevelopment) human life;

- support of the balance of the bio-, techno- and socio- spheres of urban areas;

- successful involvement of the authorities, institutional participants, construction organizations and target consumers in organization of the cycle «initiation-investment-construction-operation» of construction objects that are comfortably implemented o the existing ecosystem of the development territory (the parameters of which in the EU are the subject of increased attention).

In Germany and Japan, the tenderer (developer) who has submitted a tender with a proposition that includes solutions for the targeted dominants of biosphere compatibility of construction, gains a significant advantage over other competitors. In those countries, the biosphere compatibility leaves by priorities behind even the criterion of «profitability / rationality of cost estimates».

Under conditions of continuing slowdown in activation of the construction market, decrease of the number of construction projects to be prepared and implemented and respective decrease in the volumes of construction and special works, there is a systemic trajectory of movement of organization of the construction activity towards growth of the requirements of the leading project participants as to biosphere compatibility in real estate development as a main component of reliability and competitive ability of construction projects, one of the key requirements for their successful implementation - throughout the whole duration of the project life cycle.

In our country there are no effective mechanisms to enhance the motivation of construction participants to engage the principles of biosphere compatibility at development of architectural and construction solutions. This tendency generates contradicting requirements and evaluation criteria for projects dealing with development of new product sand services. Under such circumstances, innovative mechanisms for managing construction projects and programs based on modernization of the investmentconstruction cycle and the systems of organization of construction based on the principles of biosphere compatibility are of particular relevance. Implementation of those principles in the face of ongoing downturn in construction sector becomes an important factor in attracting investments for 
domestic construction activity from foreign partners that adhere to the basis of biosphere compatible construction and declare strategic intentions to invest in Ukrainian construction activity on the above principles.

Therefore, the transition to biosphere-compatible construction in Ukraine should be assessed as an important strategic perspective that will influence the reform of the content and architectural and structural, technical and organizational-technological standards of construction.

\section{REFERENCES}

1. «Зеленые» здания Украины. https://www.breeam.com/

2. Офіційний сайт компанії Life House Building. - Режим доступу: http://lhb.com.ua/

3. Офіційний сайт компанії Ecopan. - Режим доступу: https://ecopanua.com/

4. Orlovs'ka Y. Green investments' programs as an element of industry's international mpetitiveness (on example of construction industry) / Y. Orlovs'ka, O. Kvaktun, V. Chala, M. Vovk // Marketing and Management of Innovations. - 2017. - № 3, C. 366 - 377.

5. Визначення тривалості будівництва об'єктів: ДСТУ Б А.3.122:2013 / Мінрегіонбуд України. - Вид. офіц. - Чинний від 2014-01-01. - Київ, 2014. - 30 с. - (Національний стандарт України).

6. Организационно-технологическая и экономическая надежность в строительстве / В. Р. Млодецкий, Р. Б. Тян, В. В. Попова, А. А. Мартыш. - Днепропетровск : Наука и образование, 2013. - 193 с.

7. Большаков В. І. Фактори, що здійснюють визначальний вплив на показники ефективності організаційно-технологічних рішень будівництва доступного житла [Електронний ресурс] / В. І. Большаков, Т. С. Кравчуновська, С. П. Броневицький // Вісник Придніпровської державної академії будівництва та архітектури. - 2016. - № 5. C. 61-70. - Режим доступу: http://nbuv.gov.ua/UJRN/Vpabia_2016_5_10

8. Большаков В. І. Фактори, що здійснюють визначальний вплив на показники ефективності організаційно-технологічних рішень будівництва доступного житла [Електронний ресурс] / В. І. Большаков, Т. С. Кравчуновська, С. П. Броневицький // Вісник Придніпровської державної академії будівництва та архітектури. - 2016. - № 5. C. 61-70. - Режим доступу: http://nbuv.gov.ua/UJRN/Vpabia_2016_5_10

9.Стан реалізації ключових завдань Державного агентства 3 енергоефективності та енергозбереження України у 2015 році 
[Електронний ресурс]. - Режим доступу: http://saee.gov.ua/sites/default/ files/Presentation_2015.pdf

10. Про енергетичну ефективність будівель: Закон України від 1 липня 2019 року № 33 [Електронний ресурс]. - Режим доступу: https://zakon.rada.gov.ua/laws/show/2118-19

11. Про внесення змін до деяких законів України щодо забезпечення конкурентних умов виробництва електричної енергії з альтернативних джерел енергії: Закон України від 25 травня 2019 року № 2712-VIII [Електронний ресурс]. - Режим доступу: https://zakon.rada.gov.ua/laws/ show/2712-viii

12. Про оцінку впливу на довкілля: Закон України від 23 травня 2017 року № 29 [Електронний ресурс]. - Режим доступу: https: https://zakon.rada.gov.ua/laws/show/2059-19

13. Реалізовані проекти Державного агентства з енергоефективності та енергозбереження України [Електронний ресурс]. - Режим доступу: http://saee.gov.ua/uk/business/realizovaniproekty

14. Повноваження Комітетів Будівельної палати України [Електронний pecypc]. - Режим доступу: http://budpalata.com.ua/ category/povnovagenya-komitets

\section{Information about the author:} Chernyshev D.,

DSc (Eng.), Associate Professor, First Vice-Rector, Kyiv National University of Construction and Architecture 31, Povitroflotsky Ave., Kyiv, 03037, Ukraine 
Publishing house "Liha-Pres"

9 Kastelivka str., Lviv, 79012, Ukraine

44 Lubicka str., Toruń, 87-100, Poland

Printed by the publishing house "Liha-Pres"

Passed for printing: September 17, 2019. A run of 150 copies. 